NISTIR 7364

\title{
Database Tools for Modeling Emissions and Control of Air Pollutants from Consumer Products, Cooking, and Combustion
}

Cynthia Howard-Reed

Brian Polidoro 
NISTIR 7364

\title{
Database Tools for Modeling Emissions and Control of Air Pollutants from Consumer Products, Cooking, and Combustion
}

\author{
Cynthia Howard-Reed \\ Building and Fire Research Laboratory, NIST \\ Brian Polidoro \\ Building and Fire Research Laboratory, NIST
}

November 2006

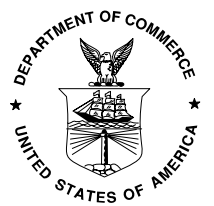

U.S. Department of Commerce Carlos M. Gutierrez, Secretary

Technology Administration Robert Cresanti, Undersecretary of Commerce for Technology 


\begin{abstract}
In order to estimate building contaminant concentrations and associated occupant exposures, indoor air quality (IAQ) model users require data related to source strengths and other contaminant transport mechanisms (e.g. sinks, filters). Much of this information exists in the literature; however, it is not readily accessible, thereby requiring users to expend significant efforts in searching for this information. To support the modeling process, the National Institute of Standards and Technology (NIST) has created a series of model input databases for use in its multizone IAQ and ventilation model CONTAM. As part of this effort, a standard data entry format was developed, as well as a computer program to search the database for specific records and build a CONTAM input library. These databases and tools can serve as a basis for building an extensive collection of model input parameters, assessing the quality and completeness of existing data sets, and allow for identification of significant data gaps.
\end{abstract}

Keywords: database, indoor air quality, transport model, volatile organic compounds, particles, exposure 


\section{Table of Contents}

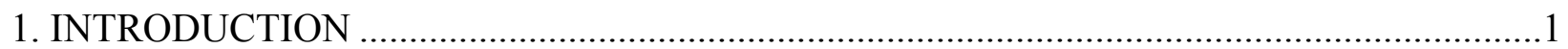

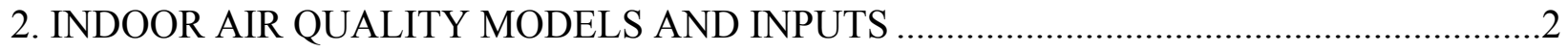

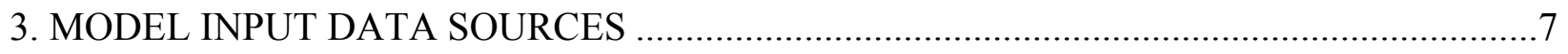

4. MODEL INPUT DATABASE STRUCTURES AND TOOLS ..........................................

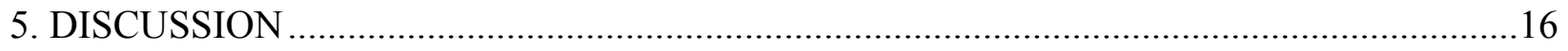

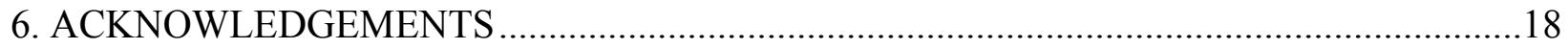

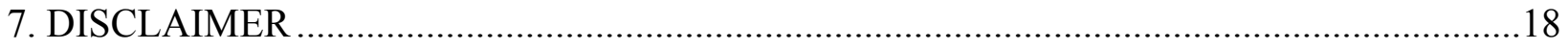

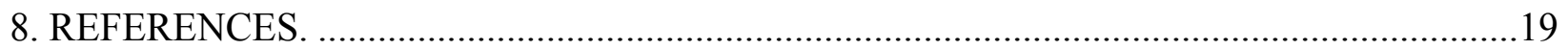
APPENDICES

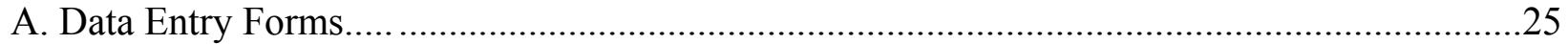

B. ContamLink 2.4 User Manual ........................................................... 48 



\section{INTRODUCTION}

Indoor air quality (IAQ) models can be used to predict airflows, contaminant concentrations and building occupant exposures in a given indoor environment. In order to generate such results, however, IAQ models require the user to provide a wide range of input data including envelope leakage information, weather, ventilation system characteristics, contaminant source emission rates, sink removal rates, occupant schedules, and air cleaner removal rates. Many of the required model inputs are available in the literature; however, these data have generally not been compiled in a readily accessible source, thereby requiring users to search for model input parameters. To facilitate the IAQ modeling process and allow for assessment of the data quality and completeness, there is a need for well-designed databases of measured contaminant modeling data.

In response to this need, the National Institute of Standards and Technology (NIST) created several searchable databases for model input data. These databases may be used to organize volatile organic compound (VOC) emission rates from building materials, particle and inorganic gas emission rates from combustion sources, particle deposition rates, VOC sorption rates, and particle filtration. This process involved collecting representative data from the literature, designing a database format to standardize data entry, entering example data into the database, validating data entry, and developing a computer program to search the database for specific records to use in the multizone IAQ and ventilation model, CONTAM. The resulting databases and tools provide standardization that is needed for consistency and reliability in reporting, accessing, and manipulating IAQ model input data. 


\section{INDOOR AIR QUALITY MODELS AND INPUTS}

Although the model input databases compiled as part of this effort can be used in any IAQ model, this report will focus on their use in NIST's airflow and pollutant transport model CONTAM (Walton and Dols, 2005). The CONTAM software and manual may be downloaded from the following website: http://www.bfrl.nist.gov/IAQanalysis/. In summary, CONTAM is a multizone model that treats a building as a system of interconnected, well-mixed zones between which airflow and pollutants are transported. This macroscopic approach is implemented by constructing a network of elements describing the flow paths (heating, ventilating, and air conditioning (HVAC) ducts, doors, windows, cracks, etc.) between the zones of a building. The network nodes represent the zones and duct segments, which are modeled with a single pressure, temperature, and pollutant concentration. CONTAM has a graphical interface that allows users to draw a building's zones and add airflow paths, ventilation systems, contaminant sources and sinks, and building occupants.

The program first calculates airflow rates between zones by solving for the pressure in each zone based on a mass balance of air. After calculating the airflow between zones and ambient, zonal pollutant concentrations are calculated by applying mass balance equations to the zones, which may also contain pollutant sources or sinks. The following mass balance may be used to describe contaminant transport in a multizone building:

$$
\frac{\mathrm{dm}_{\alpha, \mathrm{i}}}{\mathrm{dt}}=-\mathrm{R}_{\alpha, \mathrm{i}} \mathrm{C}_{\alpha, \mathrm{i}}-\sum_{\mathrm{j}} \mathrm{F}_{\mathrm{i}, \mathrm{j}} \mathrm{C}_{\alpha, \mathrm{i}}+\sum_{\mathrm{j}} \mathrm{F}_{\mathrm{j}, \mathrm{i}}\left(1-\eta_{\alpha, \mathrm{j}, \mathrm{i}}\right) \mathrm{C}_{\alpha, \mathrm{j}}+\mathrm{m}_{\mathrm{i}} \sum_{\beta} \mathrm{k}_{\alpha, \beta} \mathrm{C}_{\beta, \mathrm{i}}+\mathrm{G}_{\alpha, \mathrm{i}}
$$

where:

$$
\begin{aligned}
& \mathrm{m}_{\alpha, \mathrm{i}}=\text { mass of contaminant } \alpha \text { in zone } \mathrm{i}(\mathrm{kg}) \\
& \mathrm{R}_{\alpha, \mathrm{i}}=\text { removal coefficient for contaminant } \alpha \text { in zone } \mathrm{i}(\mathrm{kg} / \mathrm{s}) \\
& \mathrm{C}_{\alpha, \mathrm{i}}=\text { concentration mass fraction of contaminant } \alpha \text { in zone } \mathrm{i}(\mathrm{kg} / \mathrm{kg}) \\
& \mathrm{F}_{\mathrm{i}, \mathrm{j}}=\text { rate of airflow from zone } \mathrm{i} \text { to zone } \mathrm{j}(\mathrm{kg} / \mathrm{s}) \\
& \mathrm{F}_{\mathrm{j}, \mathrm{i}}=\text { rate of airflow from zone } \mathrm{j} \text { to zone } \mathrm{i}(\mathrm{kg} / \mathrm{s}) \\
& \eta_{\alpha, \mathrm{j}, \mathrm{i}}=\text { filter efficiency in the path from zone } \mathrm{j} \text { to zone } \mathrm{i}(\mathrm{kg} / \mathrm{kg}) \\
& \mathrm{C}_{\alpha, \mathrm{j}}=\text { concentration mass fraction of contaminant } \alpha \text { in zone } \mathrm{j}(\mathrm{kg} / \mathrm{kg}) \\
& \mathrm{m}_{\mathrm{i}}=\text { mass of air in zone } \mathrm{i}(\mathrm{kg}) \\
& \mathrm{k}_{\alpha, \beta}=\text { kinetic reaction coefficient in zone i between species } \alpha \text { and } \beta(1 / \mathrm{s}) \\
& \mathrm{C}_{\beta, \mathrm{i}}=\text { concentration mass fraction of contaminant } \beta \text { in zone } \mathrm{i}(\mathrm{kg} / \mathrm{kg}) \\
& \mathrm{G}_{\alpha, \mathrm{i}}=\text { generation rate of contaminant } \alpha \text { in zone } \mathrm{i}(\mathrm{kg} / \mathrm{kg})
\end{aligned}
$$

The user must supply data regarding airflow paths, contaminant source emission rates, contaminant removal rates, chemical reaction coefficients, filter efficiencies and occupant schedules. In a previous effort, NIST created a library of airflow leakage elements, wind pressure coefficients, and ventilation system schedules to aid the user when adding airflow path information (Persily and Ivy, 2001). The project described in this report focused on creating databases for the model input parameters needed to model exposure to air pollutants from consumer products, cooking, and combustion. These parameters include source emission rates $\left(\mathrm{G}_{\alpha, \mathrm{i}}\right)$, contaminant sinks and deposition rates $\left(\mathrm{R}_{\alpha, \mathrm{i}}\right)$, and particle filter efficiencies $\left(\eta_{\alpha, \mathrm{j}, \mathrm{i}}\right)$. 


\section{Source Models}

The generation rate of indoor contaminants has been described with several different source models. A summary of the source models currently available in CONTAM is provided in Table 1. It should be noted that there are additional source models available in the literature.

Table 1. Source models used to characterize source emission rates in CONTAM.

\begin{tabular}{|c|c|c|}
\hline Source Model Name & Equation & Example Uses \\
\hline Constant Coefficient Model & $\begin{array}{l}\mathrm{G} \\
\mathrm{G}=\text { generation rate }\end{array}$ & $\begin{array}{l}\text { Dry VOC sources }(e . g ., \\
\text { linoleum) } \\
\text { Particles from cooking }\end{array}$ \\
\hline Pressure Driven Model & $\begin{array}{l}\mathrm{G}^{*} \Delta \mathrm{P}^{\mathrm{n}} \\
\Delta \mathrm{P}=\text { pressure difference } \\
\mathrm{n}=\text { pressure exponent }\end{array}$ & Contaminated soil gas \\
\hline Cutoff Concentration Model & $\begin{array}{l}\mathrm{G}\left(1-\frac{\mathrm{C}}{\mathrm{C}_{\text {cut }}}\right) \\
\mathrm{C}=\text { current concentration } \\
\mathrm{C}_{\text {cut }}=\text { cutoff concentration at which } \\
\text { emission ceases }\end{array}$ & $\begin{array}{l}\text { Sources within a confined space } \\
\text { (e.g., mothballs in a closet) }\end{array}$ \\
\hline Decaying Source Model & $\begin{array}{l}\mathrm{G}_{0} \exp \left(-\mathrm{t} / \mathrm{t}_{\mathrm{c}}\right) \\
\mathrm{G}_{0}=\text { initial generation rate } \\
\mathrm{t}=\text { time since start of emission } \\
\mathrm{t}_{\mathrm{c}}=\text { time constant }\end{array}$ & Wet VOC sources (e.g., paint) \\
\hline $\begin{array}{l}\text { Boundary Layer Diffusion } \\
\text { Model }\end{array}$ & $\begin{array}{l}\text { hdA }\left(C_{i}-\frac{C_{s}}{k}\right) \\
h=\text { film mass transfer coefficient over sink } \\
d=\text { film density of air } \\
\mathrm{A}=\text { surface area } \\
C_{i}=\text { concentration in air } \\
C_{s}=\text { concentration at surface of material } \\
\mathrm{k}=\text { partition coefficient }\end{array}$ & Reversible sinks \\
\hline Burst Source Model & Fixed mass added to zone instantaneously & $\begin{array}{l}\text { Occupant activities (e.g., } \\
\text { spraying an air freshener, } \\
\text { changing kitty litter) }\end{array}$ \\
\hline Power Law Model & $\begin{array}{l}\text { If } \mathrm{t}<\mathrm{t}_{\mathrm{p}} \text {, then } \\
S(t)=a t_{p}^{-b} \\
\text { Else } \\
S(t)=a t^{-b} \\
\mathrm{t}=\text { time } \\
\mathrm{a}, \mathrm{b}, \mathrm{t}_{\mathrm{p}}=\text { empirical coefficients }\end{array}$ & "Dry" materials emissions \\
\hline Peak Model & $\begin{array}{l}S(t)=a \exp \left\{-0.5\left[\frac{\ln \left(\frac{t}{t_{p}}\right)}{b}\right]^{2}\right\} \\
\mathrm{a}, \mathrm{b}, \mathrm{t}_{\mathrm{p}}=\text { empirical coefficients }\end{array}$ & "Wet" material emissions \\
\hline
\end{tabular}


As shown in Table 1, each model is applicable to specific types of sources. For example, an exponential model better describes VOC emissions from a "wet" source than a constant source model. The modeler chooses which source model to apply; however, use of the different source models requires knowledge of the specific coefficients. The constant coefficient, first-order decay, power law and peak models in Table 1 are empirically-based. Thus, the user must find the model coefficients that are linked to specific experimental tests. The mass transfer approach (boundary layer diffusion model) is physically-based, thus its coefficients may be estimated using contaminant and material properties. However, the mass transfer values must still be determined.

To determine the empirical model coefficients or to validate the physical models, source emission rates have been experimentally measured for hundreds of consumer products and combustion appliances. Source emissions testing is typically completed in controlled laboratory chambers ranging in size from approximately $3.5 \times 10^{-5} \mathrm{~m}^{3}$ (field and laboratory emission cells) to larger than $10 \mathrm{~m}^{3}$ (room size) (ASTM 1997). While there are currently no standard emission rate test methods for consumer products and combustion appliances, researchers typically report test facility characteristics, test conditions, and product/appliance characteristics.

\section{Deposition Models}

Deposition is a significant removal mechanism of particles indoors and needs to be accounted for when modeling particle transport. The rate of deposition depends on several factors including characteristics of the particle (e.g., size and charge), room surfaces, and airflow (Nazaroff et al. 1993). Deposition of particles is typically reported in the literature in terms of a deposition velocity $\left(v_{d}\right)$ or a deposition rate $\left(k_{d}\right)$. The deposition velocity sink model is:

$$
R_{\alpha}(t)=v_{d} A_{s} \rho_{a i r}(t) C_{\alpha}(t)
$$

where:

$\mathrm{R}_{\alpha}(\mathrm{t})=$ removal rate at time $\mathrm{t}(\mathrm{kg} / \mathrm{s})$

$v_{\mathrm{d}} \quad=$ deposition velocity $(\mathrm{m} / \mathrm{s})$

$\mathrm{A}_{\mathrm{s}} \quad=$ deposition surface area $\left(\mathrm{m}^{2}\right)$

$\rho_{\text {air }}(\mathrm{t})=$ density of air in the source zone at time $\mathrm{t}\left(\mathrm{kg} / \mathrm{m}^{3}\right)$

$\mathrm{C}_{\alpha}(\mathrm{t})=$ concentration of contaminant $\alpha$ at time $\mathrm{t}(\mathrm{kg} / \mathrm{kg})$

To use this model, the user must enter the deposition surface area and particle deposition velocity. Often it is difficult to estimate the deposition surface area, so it is lumped into a parameter known as the deposition rate, which is defined as:

$$
k_{d}=\frac{v_{d} A_{s}}{V_{z}}
$$

where:

$\mathrm{V}_{\mathrm{z}}=$ zone volume $\left(\mathrm{m}^{3}\right)$

Using the deposition rate parameter, the deposition sink model may be expressed as: 


$$
R_{\alpha}(t)=k_{d} V_{z} \rho_{\text {air }}(t) C_{\alpha}(t)
$$

To use the deposition rate model, the user must provide a deposition rate.

Researchers have measured deposition velocities and deposition rates in several different test facilities, ranging from small chambers to real buildings. Common test parameters reported by researchers include the types of furnishings, air mixing mechanisms, air change rate, and particle characteristics. As with source emission rates, no standard test method yet exists for measuring particle deposition rates.

\section{Sorption Model}

Indoor contaminant calculations use sorption models to account for the transfer of gaseous contaminants between the air phase and the material phase. The rate of adsorption depends on characteristics of the adsorbent material, the adsorbing chemical, and the boundary layer that separates them. There are several sorption models available: CONTAM currently uses the boundary layer diffusion controlled (BLDC) reversible sink/source model. The BLDC model has been documented elsewhere (Axley, 1990). In summary, it accounts for the adsorption and desorption transport of chemicals between room air and room materials. The equation used to describe this transport is:

$$
S=h d A\left(C_{i}-\frac{C_{s}}{k}\right)
$$

where:

$\mathrm{h}=$ film mass transfer coefficient over the sink $(\mathrm{m} / \mathrm{s})$

$\mathrm{d}=$ film density of air $\left(\mathrm{kg} / \mathrm{m}^{3}\right)$

$\mathrm{A}=$ surface area of the adsorbent $\left(\mathrm{m}^{2}\right)$

$\mathrm{C}_{\mathrm{i}}=$ concentration in air $(\mathrm{kg} / \mathrm{kg})$

$\mathrm{C}_{\mathrm{s}}=$ concentration in the adsorbent $(\mathrm{kg} / \mathrm{kg})$

$\mathrm{k}=$ Henry adsorption constant or the partition coefficient $(\mathrm{kg} / \mathrm{kg})$

To use the BLDC model in CONTAM, the user must provide the film mass transfer coefficient, film density of air, surface mass of adsorbent, and the partition coefficient. The first three parameters are based on physical constants and characteristics of the zone being modeled. The partition coefficient is chemical/material specific with limited values available for several indoor air chemical species and building materials in the literature (Zhang et al 2001).

\section{Filter Model}

CONTAM currently includes three filter models: constant removal efficiency, simple particle, and simple gaseous. The constant removal efficiency model describes the loss of particles or gases through a filter. As presented in Equation 6, the removal of contaminants through a filter is written as: 
Filter removal $=F(1-\eta) C$

where:

$\mathrm{F} \quad=$ airflow rate through the filter $(\mathrm{kg} / \mathrm{s})$

$\eta \quad=$ single pass removal efficiency of filter (-)

$\mathrm{C}=$ contaminant removed by filter $(\mathrm{kg} / \mathrm{kg})$

CONTAM also includes a particle filter element that allows the user to enter filter removal efficiencies as a function of particle size to create a filter performance curve for a single filter. The user is required to enter the filter data from which CONTAM generates a curve using a cubic spline fit. Another option is to choose an existing filter performance curve based on ASHRAE 52.2's Minimum Efficiency Reporting Value (MERV) System (ASHRAE 1999). Based on this evaluation system, Kowalski and Bahnfleth (2002) created several sets of filter performance curves using MERV test results. These filter performance curves have already been compiled into a CONTAM library. Users can therefore either enter their own filter curve data or choose an existing MERV curve to use in a CONTAM simulation.

CONTAM also has an air cleaner element for gaseous contaminants, which uses a removal efficiency for a given contaminant loading. As the mass of contaminant sorbed to the air cleaner media increases, the associated contaminant removal efficiency decreases. Again, CONTAM can generate a filter curve using a cubic spline fit based on user provided data. It is also possible to set a breakthrough efficiency for each contaminant. 


\section{MODEL INPUT DATA SOURCES}

The model input data considered in this report include emission rates from consumer products, building materials, cooking and combustion appliances, particle deposition rates, chemical sorption rates, and particle filter removal. For each category, several key references were identified from which to build the database structures. It should be noted that the data sources identified for this project are not intended to be all-inclusive, but, rather, representative of the literature and to serve as examples for populating the databases in the future. A user may append any of the model input databases with his or her own data.

\section{VOC Emission Rates from Consumer Products and Building Materials}

There is a great deal of VOC source emission rate data available in the literature and other sources. Although there is not a comprehensive database available, there are several abridged versions that can provide the foundation for a sound database design. Based on completeness and accessibility, the NRC material emission database (Zhang et al. 1999) and the U.S. Environmental Protection Agency (EPA) database (U.S. EPA 1999) served as the sources of emission rate data for this project.

The NRC database is a material emission database assembled by the National Research Council of Canada (NRC). The NRC database was developed in Access and includes VOC emission rate data from tests conducted in their Indoor Environment Program laboratory chambers. This database currently contains over 2300 emission rates representing 152 contaminants and 69 different materials. Each record includes approximately 80 data fields including product manufacturer information, emissions testing conditions, chemical information, emission factors, emission profiles, and comments. NRC has also provided access to this emission rate data through its indoor air quality model IA-QUEST (http://irc.nrc-cnrc.gc.ca/ie/iaq/iaquest_e.html) (Sander et al. 2005). Since the NRC database represents a collection of data from a single testing facility and it is being managed by NRC, it was considered complete and exists on its own. However, its design was used to build a second database of emission rates from the published literature described below.

In order to provide a user interactive database of VOC source emission rates, a second VOC source database was created to add emission rates from the published literature and other sources. A collection of peer-reviewed source emission rates was compiled by the Indoor Environment Management Branch of the U.S. Environmental Protection Agency (EPA) (U.S. EPA 1999). The data were stored in an Excel spreadsheet that included approximately 8500 emission rate records from 72 references reviewed through May 1999. Records represent 78 types of materials in 17 source categories. Each record contains about 70 data fields including information regarding emission source classification, emission testing conditions, chemical information and analytical methods, emission factors, emission modeling parameters if available, and comments. For this NIST project, only the data published in first degree references (e.g., peer-reviewed journal articles as opposed to conference proceedings) were used. This data subset resulted in over 800 VOC emission rates from 16 references (Brown 1999a; Brown 1999b; Kelly et al. 1999; Lundgren et al. 1999; Horn et al., 1998; Chang et al. 1997; Van der Wal et al. 1997; Schaeffer et al. 1996; Nagda et al., 1995; Chang and Guo 1994; Hodgson et al. 1993; Chang and Guo 1992; Hawkins et al. 1992; Colombo et al. 1990; Schlitt and Knoppel 1989; Wallace et al. 1987). 


\section{Cooking and Combustion Appliance Emission Rates}

Unlike VOC emission rates, there is not an existing database of combustion appliance emission rates. Thus, a literature review was conducted to identify research papers with combustion related emission rates. As a result of this search, data from 21 references are included representing emissions from gas range tops (He et al. 2004; Wallace et al. 2004; Borazzo et al. 1987; Moschandreas et al. 1987; Billick et al. 1984; Caceres et al. 1983; Traynor et al. 1982; Yamanaka et al. 1979), gas ovens (He et al. 2004; Borazzo et al. 1987; Traynor et al. 1982), gas space heaters (Apte and Traynor 1986; Billick 1985; Traynor et al. 1985; Billick et al. 1984; Caceres et al. 1983; Girman et al. 1982; Yamanaka et al. 1979), kerosene space heaters (Tamura 1987; Traynor et al. 1987a; Apte and Traynor 1986; Porter 1984; Caceres et al. 1983; Girman et al. 1982; Yamanaka et al. 1979), wood stoves (McDonald et al. 2000; Nabinger et al. 1995; McCrillis and Burnet 1990; Traynor et al. 1987b; Knight et al. 1986), wood-burning fireplaces (McDonald et al. 2000), and candles (Fine et al. 1999).

\section{Particle Deposition Rates}

Although not compiled in a database, a literature review of particle deposition rates was recently published by Lai (2002). This review included 15 key indoor particle deposition references (Lai et al. 2002; Thatcher et al. 2002; Abadie et al. 2001; Cheng 1997; Fogh et al. 1997; Nomura et al. 1997; Morawska and Jamriska 1996; Byrne et al. 1995; Xu et al. 1994; Chen et al. 1992; Van Dingenen et al. 1989; Okuyama et al. 1986; Offermann et al. 1985; Crump et al. 1983; Harrison 1979). Lai's review includes graphs of deposition rate as a function of particle size as well as information regarding the experimental test conditions including test chamber dimensions, mixing mechanism, chamber type, and chamber surface textures. The published results from other deposition studies that have been completed at NIST (Howard-Reed et al. 2003; Emmerich and Nabinger 2001) and Lawrence Berkeley Laboratory (Thatcher and Layton 1995) are also included in the deposition data set.

\section{Partition Coefficients}

Another literature review was recently completed to compile data related to material sinks (Zhang 2001). In this review, several sink model inputs are provided including partition coefficients that are used in CONTAM's BLDC model. These partition coefficients are primarily from a single reference (Bodalal 1999) that was used to build a partition coefficient model input database. Of all the model input databases constructed for this project, this one has the least amount of available data, indicating an important research need.

\section{Particle Filter Removal Efficiencies}

As discussed earlier, Kowalski and Bahnfleth (2002) have created a series of filtration performance curves based on ASHRAE 52.2's Minimum Efficiency Reporting Value (MERV) System. These curves have recently been compiled in a CONTAM library and do not require a separate database. 


\section{MODEL INPUT DATABASE STRUCTURES AND TOOLS}

The primary function of a database is to store a collection of information in a readily accessible format. A well-designed database should also allow for the assessment of data quality, trends in the observations, and data gaps. For this project, Access, a relational database management system (RDBMS), is used to create multiple searchable database structures for the compilation of IAQ model input data. The databases for this project are designed to expedite data entry by using tables of data fields that are linked by one-to-many relationships. To further aid data entry, forms were created to add data to the database tables. In most cases, the database fields for each type of model input are based on parameters reported in the published literature. To date, each model input database includes example entries from key references. The standard data format for the database also allows users to populate the databases with their own input data to build a model input library for CONTAM. Since a particle filtration database already exists in CONTAM, a separate database structure is not needed.

\section{VOC Source Emission Rate Database}

The format of the VOC source emission rate database is based on fields from both the NRC and EPA databases as well as parameters from several emission testing guides (ASTM 1997, 2001; European Guidelines 1991; and Matthews 1987). A summary of the test conditions recommended in these guides is provided in Table 2.

The resulting standard format includes the following nine tables: emission rate category (CATEGORY), type of material within category (TYPE), literature reference (REFERENCE), material properties (MATERIAL), contaminant properties (PROPERTY), environmental test conditions (TESTCOND), material test conditions (ETEST), source model equation (EQUATION), contaminant emission rate factors (CONTAMINANT). Each table contains information specific to that entity that is given in Figure 1. For example, the equation table provides a description of the equation, the equation itself, the number of required coefficients, and the corresponding source model type in CONTAM. The tables are linked to one another using a "one-to-many" relationship system (see Figure 1). For example, a single emission rate test can yield results for many different contaminants and a single reference can provide results for several different tests, etc. 
Table 2. Summary of source emission rate testing conditions guidelines.

\begin{tabular}{|c|c|c|c|c|}
\hline Parameter & $\begin{array}{c}\text { ASTM Full-Scale } \\
\text { Chambers }^{\mathrm{a}}\end{array}$ & $\begin{array}{c}\text { ASTM Small-Scale } \\
\text { Chambers }^{b}\end{array}$ & $\begin{array}{l}\text { European } \\
\text { Guideline }^{c}\end{array}$ & Matthews $^{d}$ \\
\hline $\begin{array}{l}\text { Small-scale } \\
\text { chamber volume }\end{array}$ & not applicable & $<5 \mathrm{~m}^{3}$ & $\leq 1 \mathrm{~m}^{3}$ & $\leq 1 \mathrm{~m}^{3}$ \\
\hline $\begin{array}{l}\text { Large-scale } \\
\text { chamber volume }\end{array}$ & room size & not applicable & $>10 \mathrm{~m}^{3}$ & $>15 \mathrm{~m}^{3}$ \\
\hline $\begin{array}{l}\text { Acceptable mixing } \\
\text { criteria }\end{array}$ & $\begin{array}{l}\text { tracer decay test, } \\
\text { compare measured } \\
\text { decay to theoretical } \\
\text { decay curve }\end{array}$ & $\begin{array}{l}\text { tracer decay test } \mathrm{w} / \\
\text { mixing level }>80 \%\end{array}$ & $\begin{array}{c}\text { tracer decay test, } \\
\text { compare measured } \\
\text { decay to theoretical } \\
\text { decay curve }\end{array}$ & $\begin{array}{l}\text { difference between } \\
\text { concentration } \\
\text { measurements in } \\
\text { several locations } \\
\text { should be within } \\
\text { normal uncertainty }\end{array}$ \\
\hline $\begin{array}{l}\text { Clean air } \\
\text { generation system }\end{array}$ & $\begin{array}{l}\text { inlet conc. }<2 \mu \mathrm{g} / \mathrm{m}^{3} \\
\quad \text { for single VOC, } \\
<10 \mu \mathrm{g} / \mathrm{m}^{3} \sum \mathrm{VOCs}\end{array}$ & $\begin{array}{l}\text { inlet conc. }<2 \mu \mathrm{g} / \mathrm{m}^{3} \\
\text { for single VOC, } \\
<10 \mu \mathrm{g} / \mathrm{m}^{3} \Sigma \mathrm{VOCs}\end{array}$ & $\begin{array}{l}\text { filtered/treated inlet } \\
\text { air }\end{array}$ & not specified \\
\hline Surface air velocity & mean: 0 to $0.25 \mathrm{~m} / \mathrm{s}$ & typical indoor values & $>0.1 \mathrm{~m} / \mathrm{s}$ & 0.2 to $0.4 \mathrm{~m} / \mathrm{s}$ \\
\hline $\begin{array}{l}\text { Turbulence kinetic } \\
\text { energy }\end{array}$ & $0-0.01(\mathrm{~m} / \mathrm{s})^{2}$ & not specified & not specified & not specified \\
\hline Temperature & $23{ }^{\circ} \mathrm{C} \pm 0.5^{\circ} \mathrm{C}$ & not specified & $23{ }^{\circ} \mathrm{C} \pm 0.5^{\circ} \mathrm{C}$ & $\begin{array}{l}23^{\circ} \mathrm{C} \pm 0.5^{\circ} \mathrm{C}(\mathrm{std}) \\
18^{\circ} \mathrm{C} \text { to } 35^{\circ} \mathrm{C}(\text { typ })\end{array}$ \\
\hline Relative humidity & $50 \% \pm 5 \% \mathrm{RH}$ & not specified & $45 \% \pm 5 \% \mathrm{RH}$ & $\begin{array}{c}50 \% \pm 5 \% \mathrm{RH}(\mathrm{std}) \\
20 \% \text { to } 80 \% \text { (typ) }\end{array}$ \\
\hline $\begin{array}{l}\text { Total air change } \\
\text { rate }\end{array}$ & $0.5 \mathrm{~h}^{-1}$ & not specified & $0.5 \mathrm{~h}^{-1}$ and/or $1.0 \mathrm{~h}^{-1}$ & not specified \\
\hline Chamber pressure & $\begin{array}{c}0 \mathrm{~Pa} \text { to } 250 \mathrm{~Pa} \text { above } \\
\text { ambient }\end{array}$ & not specified & not specified & not specified \\
\hline $\begin{array}{l}\text { Product } \\
\text { preparation }\end{array}$ & $\begin{array}{l}\text { preconditioning for } \\
48 \mathrm{~h}\end{array}$ & $\begin{array}{l}\text { seal product edges, } \\
\text { use realistic } \\
\text { substrates for liquid } \\
\text { applications, } \\
\text { preconditioning of } \\
\text { product }\end{array}$ & $\begin{array}{l}\text { seal product edges, } \\
\text { use realistic } \\
\text { substrates for liquid } \\
\text { applications, } \\
\text { preconditioning of } \\
\text { product }\end{array}$ & $\begin{array}{c}\text { size }<25 \% \text { of the } \\
\text { transverse area of } \\
\text { small-scale chamber, } \\
\text { product edges } \\
\text { coated, product } \\
\text { preconditioning }\end{array}$ \\
\hline Product history & $\begin{array}{c}\text { record of product } \\
\text { age, storage } \\
\text { conditions, handling, } \\
\text { transport }\end{array}$ & $\begin{array}{l}\text { record of product } \\
\text { age, treatment, } \\
\text { storage conditions, } \\
\text { handling, transport }\end{array}$ & $\begin{array}{l}\text { record of product } \\
\text { age, treatment, } \\
\text { storage conditions, } \\
\text { handling, transport }\end{array}$ & $\begin{array}{c}\text { record of } \\
\text { conditioning period }\end{array}$ \\
\hline Miscellaneous & $\begin{array}{c}\text { chamber background } \\
\text { samples, duplicate } \\
\text { samples (no fewer } \\
\text { than } 15 \% \text { of } \\
\text { samples), routine } \\
\text { calibrations }\end{array}$ & $\begin{array}{l}\text { chamber background } \\
\text { samples, routine } \\
\text { calibration, internal } \\
\text { standard, duplicate } \\
\text { samples }\end{array}$ & $\begin{array}{l}\text { chamber background } \\
\text { samples, internal } \\
\text { standard, duplicate } \\
\text { samples, routine } \\
\text { maintenance/ } \\
\text { calibrations } \\
\end{array}$ & $\begin{array}{l}\text { blanks collected in } \\
\text { chamber, total mass } \\
\text { recover tests }\end{array}$ \\
\hline
\end{tabular}
a: ASTM 1997
b: ASTM 2001
c: European Communities 1991
d: Matthews 1987 


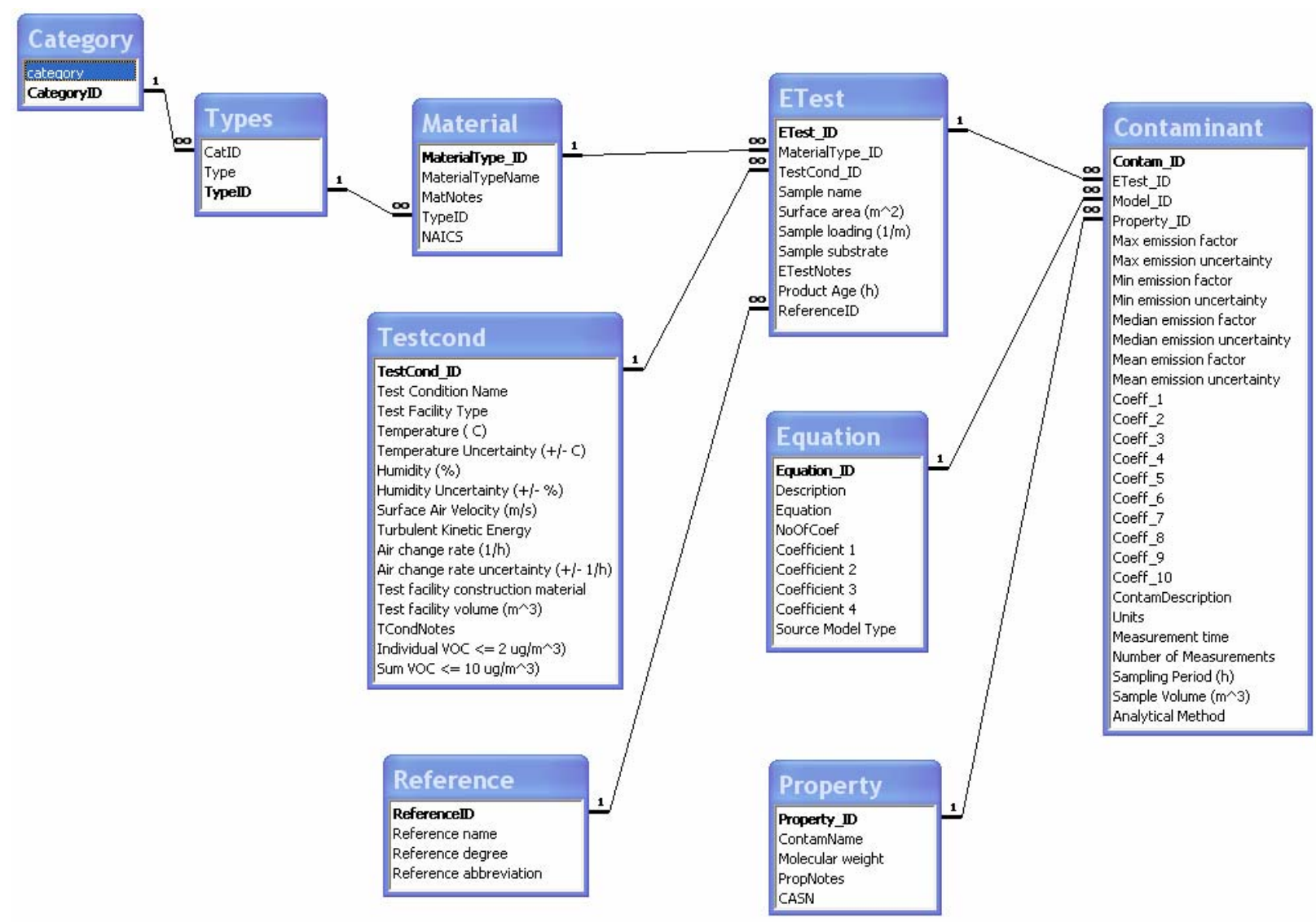

Figure 1. Relationships for tables in VOC source emissions database.

Based on the parameters in the tables in Figure 1, data entry forms were created (see Appendix A for description of form contents and example forms with data entered). As shown in Figure 1, certain parameters are assigned specific units to allow for number entries that could be used as search criteria. For example, the user could search for all records with experimental temperatures greater than $20^{\circ} \mathrm{C}$. This feature is discussed in more detail in a later section. A complete description of each data entry field is provided in Appendix A.

The NRC database was originally in Access with the 15 tables shown in Figure 2. NRC of Canada maintains this database, but has made the data contents available to CONTAM users. As a result, a link was created to transfer data to CONTAM but does not allow modification to the original NRC database structure. 


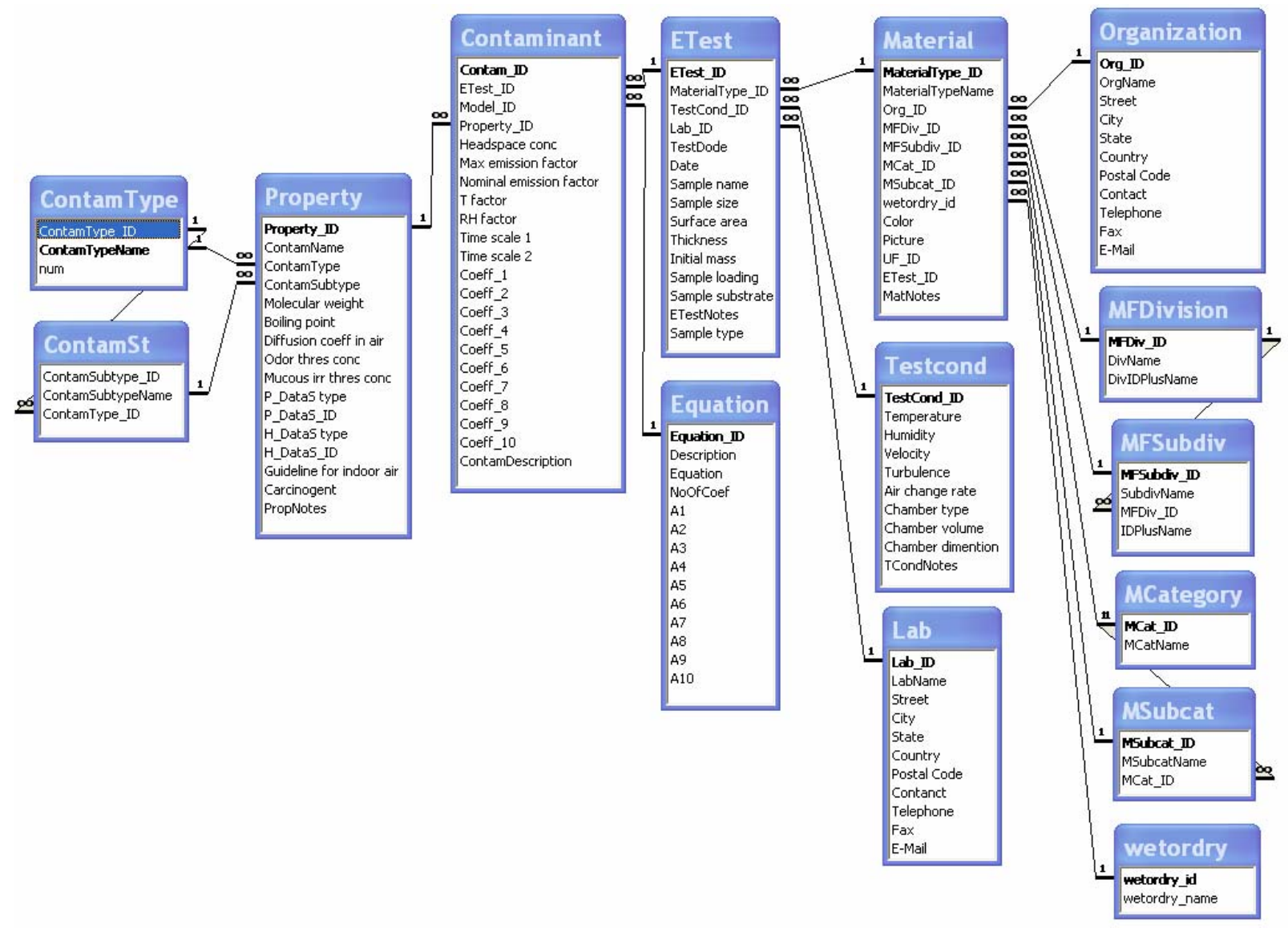

Figure 2. NRC database structure 


\section{Cooking and Combustion Appliance Database}

The cooking and combustion appliance database consists of the following nine tables linked by one-to-many relationships (see Figure 3): combustion source category (CATEGORY), combustion source type (TYPE), reference (REFERENCE), test facility specifications (FACILITY SPECS), test appliance specifications (APPLIANCE SPECS), test conditions (TEST CONDITIONS), source emission rates (EMISSION FACTORS), contaminant information (CONTAMINANT PROPERTY), and source model (EQUATION). Due to the wide range of types of combustion appliances, numerous experimental parameters were added to the test conditions table. Thus, not all data fields will be applicable to all sources. A description of data entry forms and representative forms are available in Appendix A.

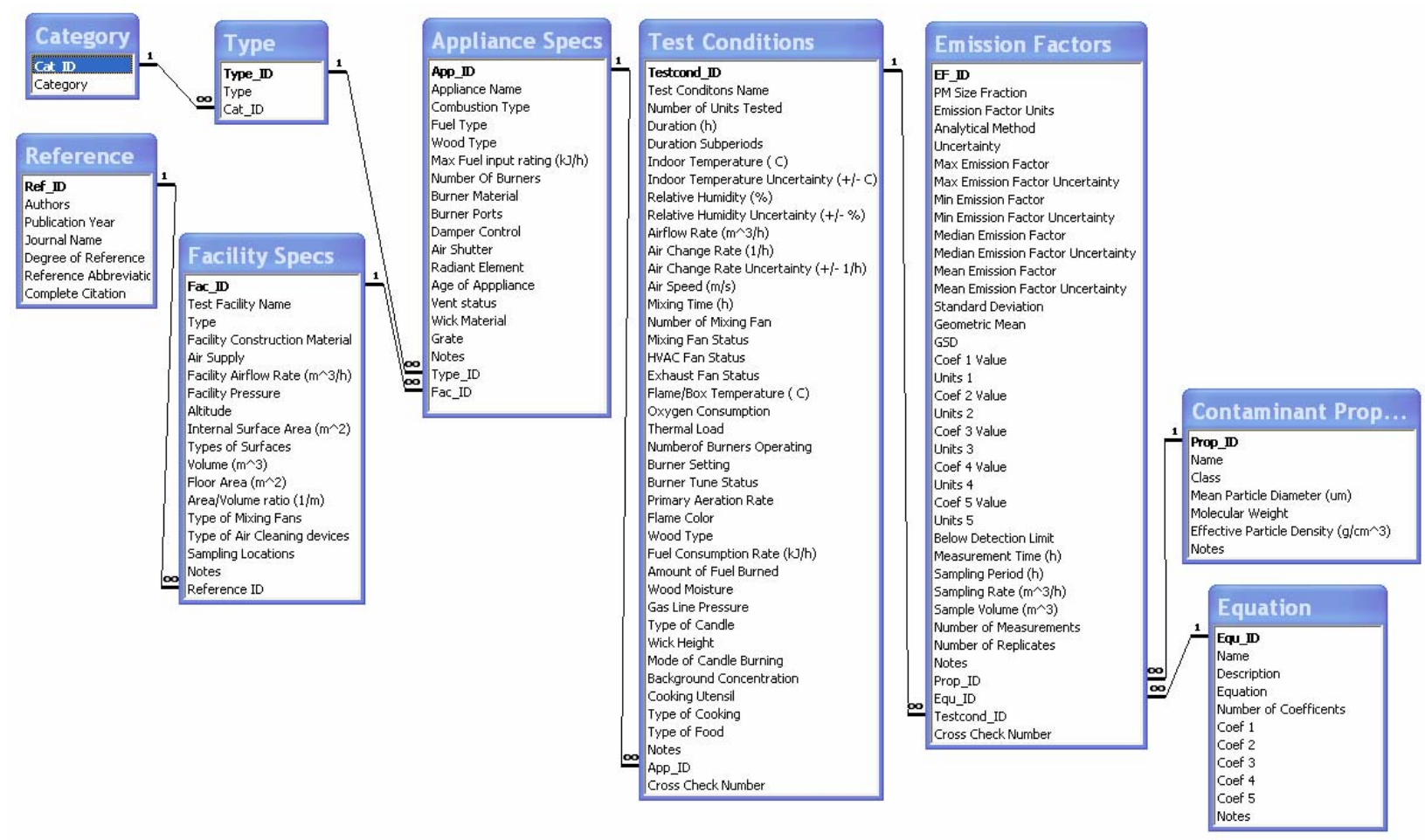

Figure 3. Cooking and Combustion Appliance Database Structure. 


\section{Particle Deposition Database}

The deposition rate database is organized such that there are many deposition rates (DEPOSITION PARAMETERS) per test condition (TEST CONDITIONS) and particle characteristic (PARTICLE); many test conditions per test facility (TEST FACILITY), and many test facilities per reference (REFERENCE) (see Figure 4). Particles are distinguished by their mean or median diameter as measured by a specific type of analytical instrument. For example, the diameters of particles sized by an optical particle counter are given as equivalent light scattering (ELS) diameters, whereas the diameters of particles sized by an aerodynamic particle sizer were given as mass median aerodynamic diameters (MMAD). For a specific example, see the data entry forms in Appendix A.

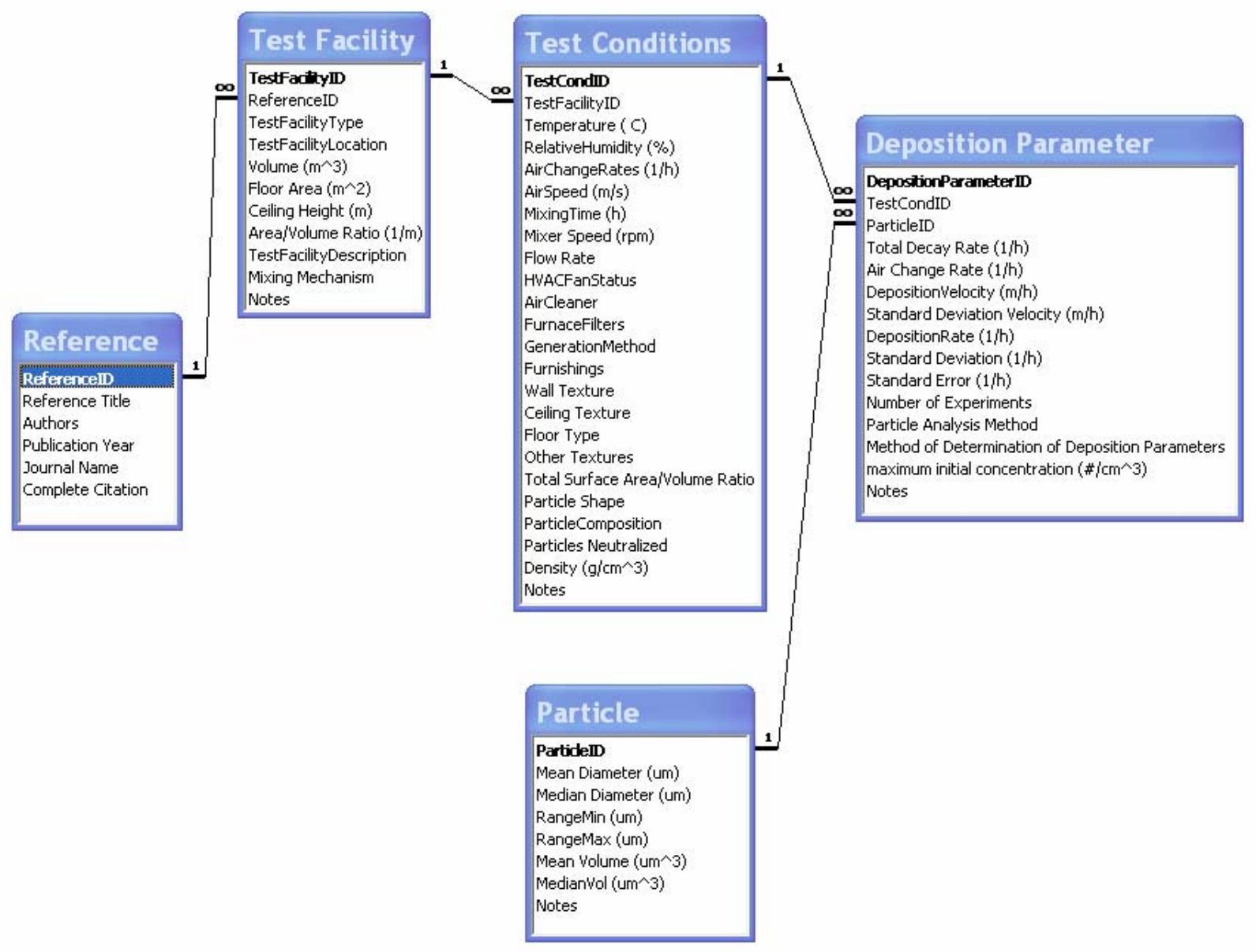

Figure 4. Particle Deposition Database Structure. 


\section{Partition Coefficient Database}

The partition coefficient database consists of seven tables linked by one to many relationships. For every chemical (CHEMICAL), sorptive material (MATERIAL), and experimental test condition (TEST CONDITIONS), there can be multiple partition coefficients (PARTITION COEFFICIENTS). Each reference (REFERENCE) could include multiple test facilities (TEST FACILITY) and multiple test conditions. Each material is grouped by type (MATERIAL TYPE). Again there is only limited partition coefficient data available in the literature from which to build a database. As this data set grows, the database structure may need to be expanded. Currently available data entry forms are available in Appendix A.

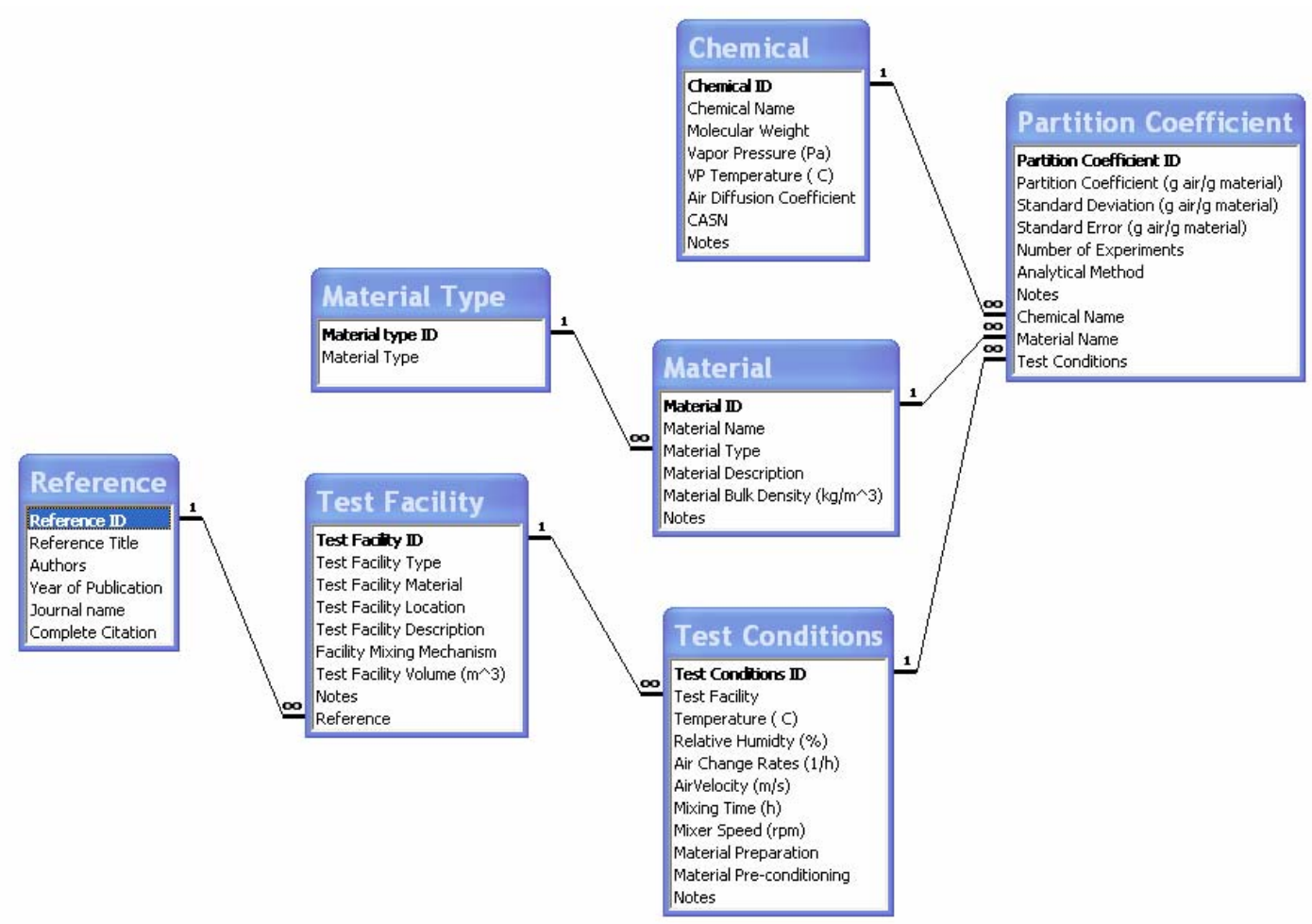

Figure 5. Partition Coefficient Database Structure.

\section{CONTAM Data Link Manager}

To aid the user in navigating the model input databases, the ContamLink 2.4 program was developed with the capabilities of browsing, searching, and selecting data for use in CONTAM. A complete description of ContamLink 2.4 and its user manual can be found in Appendix B. To download ContamLink 2.4, go to the CONTAM software page at:

http://bfrl.nist.gov/IAQanalysis/software/index.htm. 


\section{DISCUSSION}

\section{Lessons Learned}

Creation of accessible IAQ model input databases will undoubtedly make it easier for modelers to set up contaminant model scenarios. However, the convenience of such databases may also be a cause for concern. In particular, there is the potential for the data to be misinterpreted and misused, or the inclusion of poor quality data. While these are valid concerns, open access to all data is required for the verification and understanding of reported results. At this point, IAQ model input data should be considered "immature" and in need of being assessed. As such, the IAQ community could greatly benefit from model input databases that are readily accessible for assessments of data quality, trends, and gaps, as well as for convenient use in IAQ models. For example, a graph of the deposition rate data collected for the particle deposition database shows specific variations in deposition rates as a function of size (see Figure 6). In addition, by separating the data by analytical method, one can see that there is quite a bit more scatter in the deposition rates measured with a condensation nucleus counter (electrical mobility diameter) compared to an aerodynamic particle sizer (mass median aerodynamic diameter). Also, for particles of the same measured diameter, the deposition rates measured with optical particle counters (equivalent light scattering diameter) correlate well with those measured using a mass based instrument. One study reported activity mean aerodynamic diameters for submicron particles measured with a low-pressure impactor. Finally, the addition of a theoretical curve predicting deposition rates as a function of particle size shows most experimental data to follow the shape of that predictive curve but to be greater in magnitude, especially particles less than 0.1 $\mu \mathrm{m}$ in size.

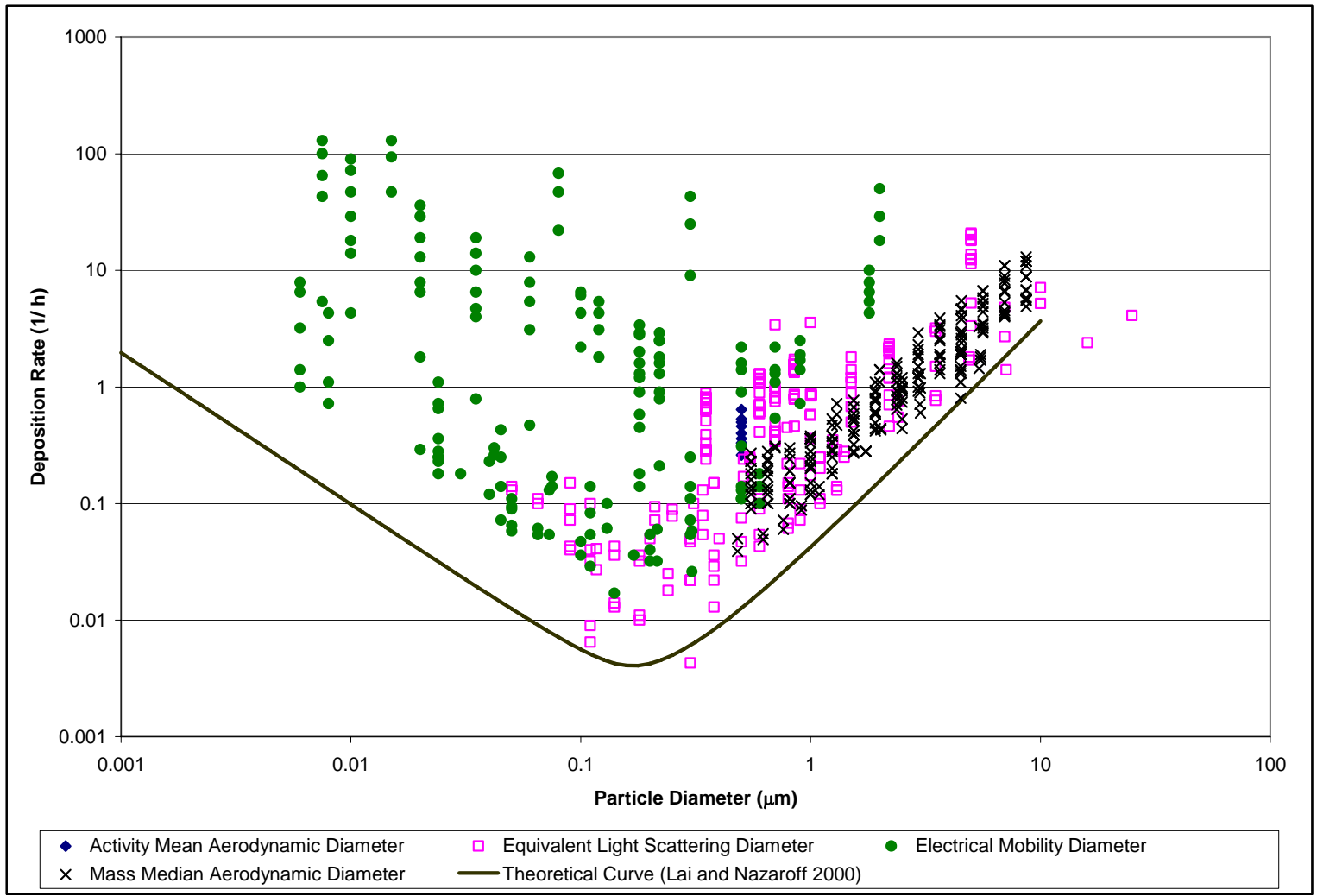

Figure 6. Particle deposition rates included in database (18 references) plotted as a function of particle size. 
Another observation made during the course of this project is the lack of consistent format for reporting model input data in the literature. This lack of consistency adds time to data compilation efforts and increases the likelihood of missing data entries and misinterpreting data. One possible solution would be to create a set of standardized specifications for reporting data, perhaps through standards development organization (SDOs) such as the American National Standards Institute (ANSI), ASTM International, or International Standards Organization (ISO). Although the current databases contain a rather long list of required fields, only a subset of these values would need to be required. The required reporting variables could be based on the database search parameters (see Table 3) or other agreed upon criteria.

\section{Future Directions}

Based on the lessons learned for this project, several potential future directions were identified. For example, another approach for compiling the data would be to use MatML, an Extensible Markup Language (XML) developed to manage and exchange materials information on the Web (www.matml.org). Currently, most data on the Web are contained in documents using the hypertext markup language (HTML). HTML was developed simply to format the display of information/data on web pages, and it does not provide a description of the data themselves. As a result, it is not easy to automate the processing of data contained in HTML documents, thereby limiting their accessibility for use by software. To address this problem, XML was developed to portray data in a structure that is meaningful to both humans and computers. MatML is a customized markup language developed specifically for materials property data.

Recently, NIST completed a demonstration project to apply MatML to VOC source emission rate data (Begley and Howard-Reed 2005). Since MatML was designed to address any materials property data, it is well-suited for application to contaminant source emission rate databases. Thus, MatML would enable the IAQ community to use relevant tags for data management and exchange via the Web that could be accessed by any IAQ computer model. The challenge to this approach is convincing the IAQ community to adopt MatML for distributing data via the web. Using MatML requires learning the language and there is a need for more user-friendly editors.

Another need is to compile data related to occupant exposure. Occupant exposure assessments are an application that would benefit from the interaction between IAQ models and model input databases. Exposure assessment is based on contaminant air concentrations in a given set of locations and the duration of occupant exposure to those contaminants in those locations. CONTAM has the capability to predict occupant exposure using predicted contaminant concentrations and a user provided occupancy schedule. To date, there are no standard exposure scenarios available to conduct a representative exposure assessment. However, exposure related survey data has been collected such as the National Human Activity Pattern Survey (NHAPS) (Tsang and Klepeis 1996). The NHAPS dataset contains 24 hour activity data for 9386 randomly selected respondents. Based on these data, it would be possible to build representative exposure scenarios that would include daily activities as well as length of stay in a specific room location. 


\section{ACKNOWLEDGEMENTS}

This work was sponsored under an Interagency Agreement with the U.S. Department of Housing and Urban Development, Office of Healthy Homes and Lead Hazards Control. The authors greatly appreciated the efforts of several people in helping to gather data for constructing the model input databases, including Jennifer Thomasen, Niren Nagda, Lisa Kim, and Ivette Morazzani. We would also like to thank the National Research Council of Canada and Gene Tucker (formerly of the U.S. Environmental Protection Agency) for use of their respective source emission rate databases.

\section{DISCLAIMER}

In an effort to enhance the scientific study of indoor air quality, published model input data are accessible on this site. However, care must be taken when using these data as they are intended for research use. Users of these data assume sole responsibility for determining the appropriateness of their use in any particular application and for any conclusions drawn from results of their use. NIST used its best efforts to deliver a high quality copy of the Database and to verify that the data contained therein have been selected on the basis of sound scientific judgment. However, NIST makes no warranties to that effect, and NIST shall not be liable for any damage that may result from errors or omissions in the Database.

Certain trade names and company products are mentioned in the text to specify adequately the products and equipment used in the test and those needed to use this software. In no case does such identification imply endorsement by the National Institute of Standards and Technology of these products and equipment, nor does it imply that the products are necessarily the best available for the purpose. 


\section{REFERENCES}

Abadie, M., Limam, K., Allard, F. (2001). Indoor particle pollution: Effect of wall textures on particle deposition. Building and Environment, 36: 821-827.

Apte, M.G., Traynor, G.W. (1986). Comparison of Pollutant Emission Rates from Unvented Kerosene and Gas Space Heaters. Proceedings IAQ '86: Managing Indoor Air for Health and Energy Conservation, American Society of Heating, Refrigerating and Air-Conditioning Engineers, Atlanta, GA, p. 405.

ASHRAE (1999). ASHRAE Standard 52.2 - 1999. American Society of Heating Refrigeration and Air Conditioning Engineers, Atlanta, GA.

ASTM (2001). Standard Practice for Full-Scale Chamber Determination of Volatile Organic Emissions from Indoor Materials/Products. D 6670-01. American Society for Testing and Materials.

ASTM (1997). Standard Guide for Small-Scale Environmental Chamber Determinations of Organic Emissions from Indoor Materials/Products. D 5116-97. American Society for Testing and Materials.

Axley, J.W. (1990). Adsorption Modeling for Macroscopic Contaminant Dispersal Analysis. NIST-GCR-90-573, National Institute of Standards and Technology, Gaithersburg, MD.

Begley, E., Howard-Reed, C. (2005). The Application of MatML to Contaminant Emissions Data. ASTM Standardization News, October, pp. 52 - 59.

Billick, I. H. (1985). Indoor Air Quality Research Related to Unvented Space Convective Heaters. ASHRAE Transactions, 91(2B): 251-260.

Billick, I., Johnson, D., Moschandreas, D., Relwani, S. (1984). An Investigation of Operational Factors that Influence Emission Rates from Gas Appliances. 3rd International Conference on Indoor Air Quality and Climate, Stockholm, pp. 181 - 187.

Bodalal, A., Zhang, J.S., Plett, E.G. (1999). Method for Measuring Internal Diffusion and Equilibrium Partition Coefficients of Volatile Organic Compounds for Building Materials. Building and Environment, 35(2): $101-110$.

Borazzo, J. E., Osborn, J.F., Fortmann, R.C., Keefer, R.L., Davidson, C.L. (1987). Modeling and Monitoring of CO, $\mathrm{NO}$ and $\mathrm{NO}_{2}$ in a Modern Townhouse. Atmospheric Environment, 21 (2): 299-311.

Brown, S.K. (1999a). Assessment of Pollutant Emissions from Dry-Process Photocopiers. Indoor Air, 9: 259-267 
Brown, S.K. (1999b). Chamber Assessment of Formaldehyde and VOC Emissions from WoodBased Panels. Indoor Air, 9: 209-215.

Byrne, M. A., Goddard, A.J.H., Lange, C., Roed, J. (1995). Stable Tracer Aerosol Deposition Measurements in a Test Chamber. J. Aerosol Sci., 26: 645-653.

Caceres, T., Soto, H., Lissi, E., Cisternas, R. (1983). Indoor House Pollution: Appliance Emissions and Indoor Ambient Concentrations. Atmospheric Environment, 17(5): 1009-1013.

Chang, J.C.S, Guo, Z. (1994). Modeling of Alkane Emissions from a Wood Stain. Indoor Air, $4: 35-39$.

Chang, J., Guo,Z. (1992). Characterization of organic emissions from a wood finishing productwood stain. Indoor Air, 2(3): 146-153.

Chang, J.C.S., Tichenor, B.A., Guo, Z., Krebs, K.A. (1997). Substrate effects on VOC emissions from a latex paint. Indoor Air, 7: 241-247.

Chen, B.T., Yeh, H.C., Cheng,Y.S. (1992). Evaluation of an Environmental Reaction Chamber. Aerosol Sci. Technology, 17: 9-24.

Cheng, Y.S. (1997). Wall Deposition of Radon Progeny and Particles in a Spherical Chamber. Aerosol Sci. and Techonlogy, 27: 131-146.

Colombo, A., De Bortoli, M., Pecchio, E., Schauenburg, H., Schlitt, H., Vissers, H. (1990). Chamber Testing of Organic Emission from Building and Furnishing Materials. The Science of the Total Environment, 91:237-249.

Crump, J. G., Flagan, R.C., Seinfeld, J.H. (1983). Particle Wall Loss Rates in Vessels. Aerosol Sci. Technol., 2: $303-309$.

Emmerich, S.J., Nabinger, S.J. (2001). Measurement and Simulation of the IAQ Impact of Particle Air Cleaners in a Single-Zone Building. HVAC\&R Research, 7(3): 223 - 244.

European Communities. (1991). European Concerted Action Indoor Air Quality \& Its Impact on Man (EUR 13593), Guideline for the Characterization of Volatile Organic Compounds Emitted from Indoor Materials and Products Using Small Test Chambers. Report No. 8. COST Project 613. Luxembourg: Office for Publications of the European Communities.

Fine, P.M., Cass, G.R., Simoneit, B.R.T. (1999). Characterization of Fine Particle Emissions from Burning Church Candles. Environmental Science \& Technology, 33(14): 2352-2362.

Fogh, C. I., Byrne, M.A., Roed, J., Goddard, A.J.H. (1997). Size Specific Indoor Aerosol Deposition Measurements and Derived I/O Concentrations Rations. Atmospheric Environment, 31: 2193-2203. 
Girman, J. R., Apte, M.G., Traynor, G.W., Allen, J.R., Hollowell, C.D. (1982). Pollutant Emission Rates from Indoor Combustion Appliances and Sidestream Cigarette Smoke. Environment International, 8: 213-221.

Harrison, A.W (1979). Quiescent Boundary Layer Thickness in Aerosol Enclosures under Convective Stirring Conditions, J. Colloid Interface Sci., 69: 563-570.

Hawkins, N.C., Luedtke, A.E., Mitchell, C.R., LoMenzo, J.A., Black, M.S. (1992). Effects of Selected Process Parameters on Emission Rates Volatile Organic Chemicals from Carpet. J. Am. Ind. Hyg. Assoc., 53(5): 275-282.

He, C., Morawska, L., Hitchins, J. Gilbert, D. (2004). Contributions from Indoor Sources to Particle Numbers and Mass Concentrations in Residential Houses. Atmospheric Environment, 38: 3405-3415.

Hodgson, A.T., Wooley, J.D., Daisey, J.M. (1993). Emissions of Volatile Organic Compounds from New Carpets Measured in a Large-Scale Environmental Chamber. J. Air Waste Manage. Assoc., 43: 316-324.

Horn, W., Ullrich, D., Seifert, B. (1998). VOC Emissions from Cork Products for Indoor Use. Indoor Air, 8: 39-46.

Howard-Reed, C., Wallace, L.A., Emmerich, S.J. (2003). Effect of Ventilation Systems and Air Filters on Decay Rates of Particles Produced by Indoor Sources in an Occupied Townhouse. Atmospheric Environment, 37: 5295-5306.

Kelly, T.J., Myers, J.D., Holdren, M.W. (1999). Testing of Household Products and Materials for Emission of Toluene Diisocyanate. Indoor Air, 9: 117-124.

Klepeis, N.E., Tsang, A.M., Behar, J.V. (1996). Analysis of the NHAPS Respondents from a Standpoint of Exposure Assessment. U.S. Environmental Protection Agency Final Report EPA/600/R-96/074, Washington D.C.

Knight, C.V., Humphreys, M.P., Pinnix, J.C. (1986). Indoor Air Quality Related to Wood Heaters. Proceedings IAQ '86, American Society of Heating, Refrigerating and Air-Conditioning Engineers, Atlanta, GA, pp. 430-447.

Kowalski, W.J., Bahnfleth, W.P. (2002). MERV Filter Models for Aerobiological Applications. Air Media, Summer:13-17.

Lai, A.C.K., Byrne, M.A., Goddard, A.J.H. (2002). Experimental Studies of the Effect of Rough Surfaces and Air Speed on Aerosol Deposition in a Test Chamber. Aerosol Science and Technology, 36: $973-982$.

Lai, A.C.K., and Nazaroff, W.W. (2000). Modeling Indoor Particle Deposition from Turbulent Flow onto Smooth Surfaces. J. Aerosol Sci., 31(4): 463 - 476. 
Lundgren, B., Jonsson B., Ek-Olausson, B. (1999). Materials Emission of Chemicals - PVC Flooring Materials. Indoor Air, 9: 202-208.

Matthews, T.G. (1987). Environmental Chamber Test Methodology for Characterizing Organic Vapors from Solid Emission Sources. Atmospheric Environment, 21(2): 321 - 329.

McCrillis, R.C., Burnet, P.G. (1990). Effects of Burnrate, Wood Species, Altitude, and Stove Type on Woodstove Emissions. Toxicology and Public Health, 6(5): 95-102.

McDonald, J.D., Zielinska, B., Fujita, E.M, Sagebiel, J.C., Chow, J.C., Watson, J.G. (2000). Fine Particles and Gaseous Emission Rates from Residential Wood Combustion. Environ. Sci.

Technol. 34: 2080-2091.

Morawska, L., and Jamriska, M. (1996). Deposition of Radon Progeny on Indoor Surfaces, $J$. Aerosol Sci., 27(2): $305-312$.

Moschandreas, D.J., Relwani, S.M., Billick, I.H., Bacriss, R.A. (1987). Emission Rates from Range-Top Burners--Assessment of Measurement Methods. Atmospheric Environment, 21(2): 285-289.

Nabinger, S.J., Persily, A.K., Sharpless, K.S., Wise, S.A. (1995). Measurements of Indoor Pollutant Emissions form EPA Phase II Wood Stoves. NISTIR 5575, National Institute of Standards and Technology, Gaithersburg, MD.

Nagda, N.L., Koontz, M.D., Kennedy, P.W. (1995). Small-Chamber and Research-House Testing of Tile Adhesive Emissions. Indoor Air, 5: 189-195.

Nazaroff, W.W., Gadgil, A.J., Weschler, C.J. (1993). Critique of the Use of Deposition Velocity in Modeling Indoor Air Quality. STP 1205, American Society for Testing and Materials, Philadelphia, PA.

Nomura, Y., Hopke, P.K., Fitzgerald, B., Mesbah, B. (1997). Deposition of Particles in a Chamber as a Function of Ventilation Rate, Aerosol Sci. Technol., 27: 62-72.

Offermann, F.J., Sextro, R.G., Fisk, W.J., Grimsrud, D.T., Nazaroff, W.W., Nero, A.V., Revzan, K.L., Yater, J. (1985). Control of Respirable Particles in Indoor Air with Portable Air Cleaners. Atmospheric Environment, 19(11): 1761 - 1771.

Okuyama, K., Kousaka, Y., Yamamoto, S., Hosokawa, T. (1986). Particle Loss of Aerosols with Particle Diameters between 6 and $2000 \mathrm{~nm}$ in Stirred Tank. J. Colloid Interface Sci., 110(1): 214-223.

Porter, W. K. (1984). Pollutant Emissions from Kerosene Heaters and Unvented Gas Space Heaters. 3rd International Conference on Indoor Air Quality and Climate, Stockholm. 
Sander, D., Won, D., Magee, R.J. (2005). IA-QUEST Version 1.0 User's Guide. National Research Council Canada.

Schaeffer, V.H., Bhooshan, B., Chen, S.B., Sonenthal, J.S., Hodgson, A.T. (1996).

Characterization of Volatile Organic Chemical Emissions from Carpet Cushions. Journal of the Air \& Waste Management Association, 46: 813-820

Schlitt, H., Knoppel, H. (1989). Carbonyl Compounds in Mainstream and Sidestream Cigarette Smoke. Present and Future of Indoor Air Quality, pp. 197-206.

Tamura, G.T. (1987). Measurement of Combustion Products from Kerosene Heaters in a TwoStory House. ASHRAE Transactions, 93(1): 173-184.

Thatcher, T. L., Lai, A.C.K., Moreno-Jackson, R., Sextro, R.G., Nazaroff, W.W. (2002). Effects of Room Furnishings and Air Speed on Particle Deposition Rates Indoors," Atmospheric Environment, 36: 1811 - 1819.

Thatcher, T.L., Layton, D.W. (1995). Deposition, Resuspension, and Penetration of Particles within a Residence. Atmospheric Environment, 29(3): 1487-1497.

Traynor, G.W., Anthon, D.W., Hollowell, C.D. (1982). Technique for Determining Pollutant Emissions from a Gas-Fired Range. Atmospheric Environment, 16(12): 2979 - 2987.

Traynor, G. W., Apte, M.G., Carruthers, A.R., Dillworth, J.F., Grimsrud, D.T., Gundel, L.A. (1987a). Indoor Air Pollution and Inter-Room Pollutant Transport Due to Unvented KeroseneFired Space Heaters. Environmental International, 13: 159-166.

Traynor, G. W., Apte, M.G., Carruthers, A.R., Dillworth, J.F., Grimsrud, D.T., Thompson, W.T. (1987b). Indoor Air Pollution Due to Emissions from Wood-Burning Stoves. Environmental Science \& Technology, 21(7): 691-697.

Traynor, G. W., Girman, J.R., Apte, M.G., Dillworth, J.F., White, P.D. (1985). Indoor Air Pollution Due to Emissions from Unvented Gas Fired Space Heaters. Journal of the Air Pollution Control Association, 35 (3): 231-237.

Tsang, A.M., Klepeis, N.E. (1996). Descriptive Statistics Tables from a Detailed Analysis of the National Human Activity Pattern Survey (NHAPS) Data. U.S. Environmental Protection Agency Final Report EPA/600/R-96/148, Washington D.C.

U.S. EPA (1999). Sources of Indoor Air Emissions. U.S. Environmental Protection Agency.

Van Der Wal, J. F., Hoogeveen, A.W., Wouda, P. (1997). The Influence of Temperature on the Emission of Volatile Organic Compounds from PVC Flooring, Carpet, and Paint. Indoor Air, 7:215-221. 
Van Dingenen, R.V., Raes, F., Vanmarcke, H. (1989). Molecule and Aerosol Particle Wall Losses in Smog Chambers Made of Glass. J. Aerosol Sci., 20(1): 113 - 122.

Wallace, L.A., Emmerich, S.J., Howard-Reed, C. (2004). Source Strengths of Ultrafine and Fine Particles Due to Cooking with a Gas Stove. Environmental Science \& Technology, 38(8): 2304 2311.

Wallace, L.A., Pellizzari, E., Leaderer, B., Zelon, H, Sheldon, L. (1987). Emissions of Volatile Organic Compounds from Building Materials and Consumer Products. Atmospheric Environment, 21(2): 385-393.

Walton, G.N., Dols, W.S. (2005). CONTAM 2.4 User Guide and Program Documentation. NISTIR 7251, National Institute of Standards and Technology.

Xu, M., Nemotollahi, M., Sextro, R.G., Gadgil, A.J., Nazaroff, W.W. (1994). Deposition of Tobacco Smoke Particles in a Low Ventilation Room. Aerosol Sci. Technol., 20: 194-206.

Yamanaka,S., Hirose, H., Takada, S. (1979). Nitrogen Oxides Emissions from Domestic Kerosene-fired and Gas-fired Appliances. Atmospheric Environment, 13(3): 407-412.

Zhang, J.S., Chen, Q., and Zhang, J. (2001). Modeling VOC Sorption of Building Materials and Its Impact on Indoor Air Quality, ASHRAE RP-1097, American Society of Heating Refrigeration and Air Conditioning Engineers, Atlanta, GA.

Zhang, J.S., Shaw, C.Y., Sander, D., Zhu, J.P., Huang, Y. (1999). MEDB-IAQ: A Material Emission Database and Single-Zone IAQ Simulation Program - A Tool for Building Designers, Engineers and Managers. National Research Council Canada. 


\section{APPENDIX A - DATA ENTRY FORMS}

\section{EPA VOC Source Emission Rate Database Entry Forms}

\section{Eg Reference Input}

R

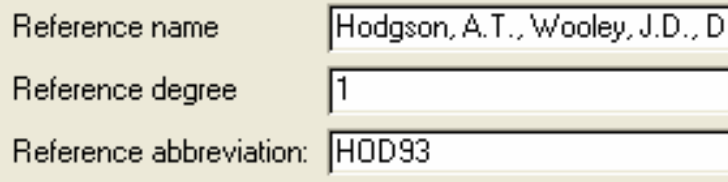

Table Name: Reference

\begin{tabular}{|l|l|c|c|}
\hline Data Field & Field Description & Data Type & Units \\
\hline Reference name & Complete citation for reference & Text & \\
\hline Reference degree & $\begin{array}{l}\text { Reflects peer review status of reference. For example, a } \\
1^{\text {st }} \text { degree reference indicates journal level review, 2 } \\
\text { degree reference indicates conference level review, and } \\
3^{\text {rd }} \text { degree reference indicates internal review. }\end{array}$ & Number & \\
\hline $\begin{array}{l}\text { Reference } \\
\text { abbreviation }\end{array}$ & $\begin{array}{l}\text { Consists of the first three letters of the first author's last } \\
\text { name and abbreviated year of publication. }\end{array}$ & Text & \\
\hline
\end{tabular}

\section{믐 Material Input}

\begin{tabular}{|c|c|c|c|}
\hline \multirow[t]{2}{*}{ | } & MaterialTypeName & \multicolumn{2}{|l|}{ Carpet 2_H0D93 } \\
\hline & MatNotes & \multicolumn{2}{|c|}{$\begin{array}{l}\text { Residential; Polypropylene primary backing; Polyurethane } \\
\text { secondary backing: } 100 \% \text { Nylon fiber; cut pile }\end{array}$} \\
\hline & NAICS & \multicolumn{2}{|l|}{31411} \\
\hline & TypelD & Carpet- synthetic fiber & - \\
\hline & cord: $\mathbf{1 4}|4| \Gamma$ & $\overline{1} ・|川| * \mid$ & \\
\hline
\end{tabular}

Table Name: Material

\begin{tabular}{|l|l|c|c|}
\hline Data Field & Field Description & Data Type & Units \\
\hline MaterialTypeName & $\begin{array}{l}\text { Internal reference descriptor with Reference } \\
\text { abbreviation }\end{array}$ & Text & \\
\hline MatNotes & Relevant information describing material & Text & \\
\hline NAICS & $\begin{array}{l}\text { North American Industry Classification System } \\
\text { number }\end{array}$ & Number & \\
\hline TypeID & Link to material type &
\end{tabular}




\section{묨 Test Input}

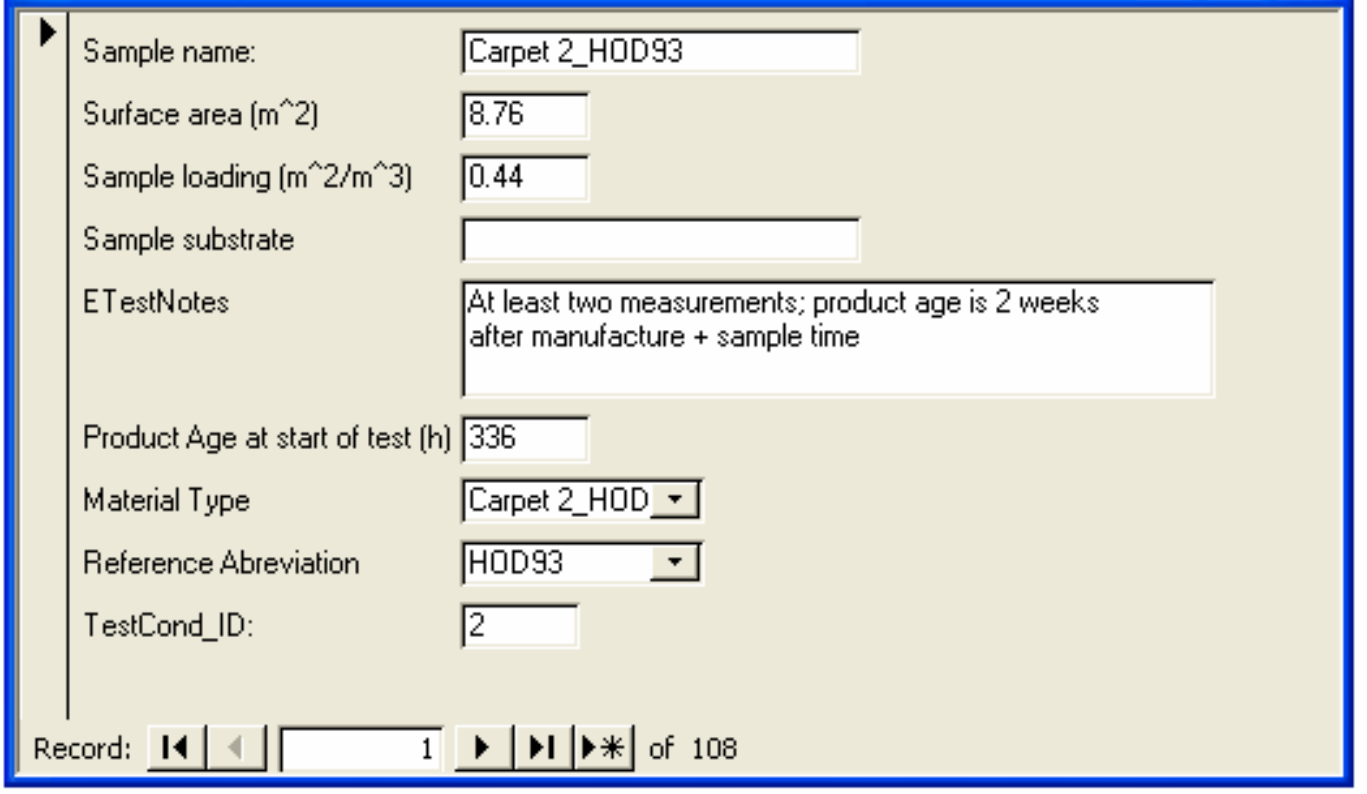

Table Name: ETest

\begin{tabular}{|l|l|c|c|}
\hline Data Field & Field Description & Data Type & Units \\
\hline Sample name & Internal reference descriptor with Ref. abbreviation & Text & \\
\hline Surface area & Product surface area exposed in test facility & Number & $\mathrm{m}^{2}$ \\
\hline Sample loading & Product surface area to test facility volume ratio & Number & $\mathrm{m}^{2} / \mathrm{m}^{3}$ \\
\hline Sample substrate & $\begin{array}{l}\text { Composition of material on which test product is } \\
\text { applied }\end{array}$ & Text & Text \\
\hline $\begin{array}{l}\text { ETestNotes } \\
\text { Slample } \\
\text { start of test }\end{array}$ & Age of sample at star of test & Number & $\mathrm{h}$ \\
\hline Material Type & Link to material type name & Number & \\
\hline $\begin{array}{l}\text { Reference } \\
\text { Abbreviation }\end{array}$ & Link to reference abbreviation & Number & \\
\hline TestCond_ID & Link to test conditions number & Number & \\
\hline
\end{tabular}




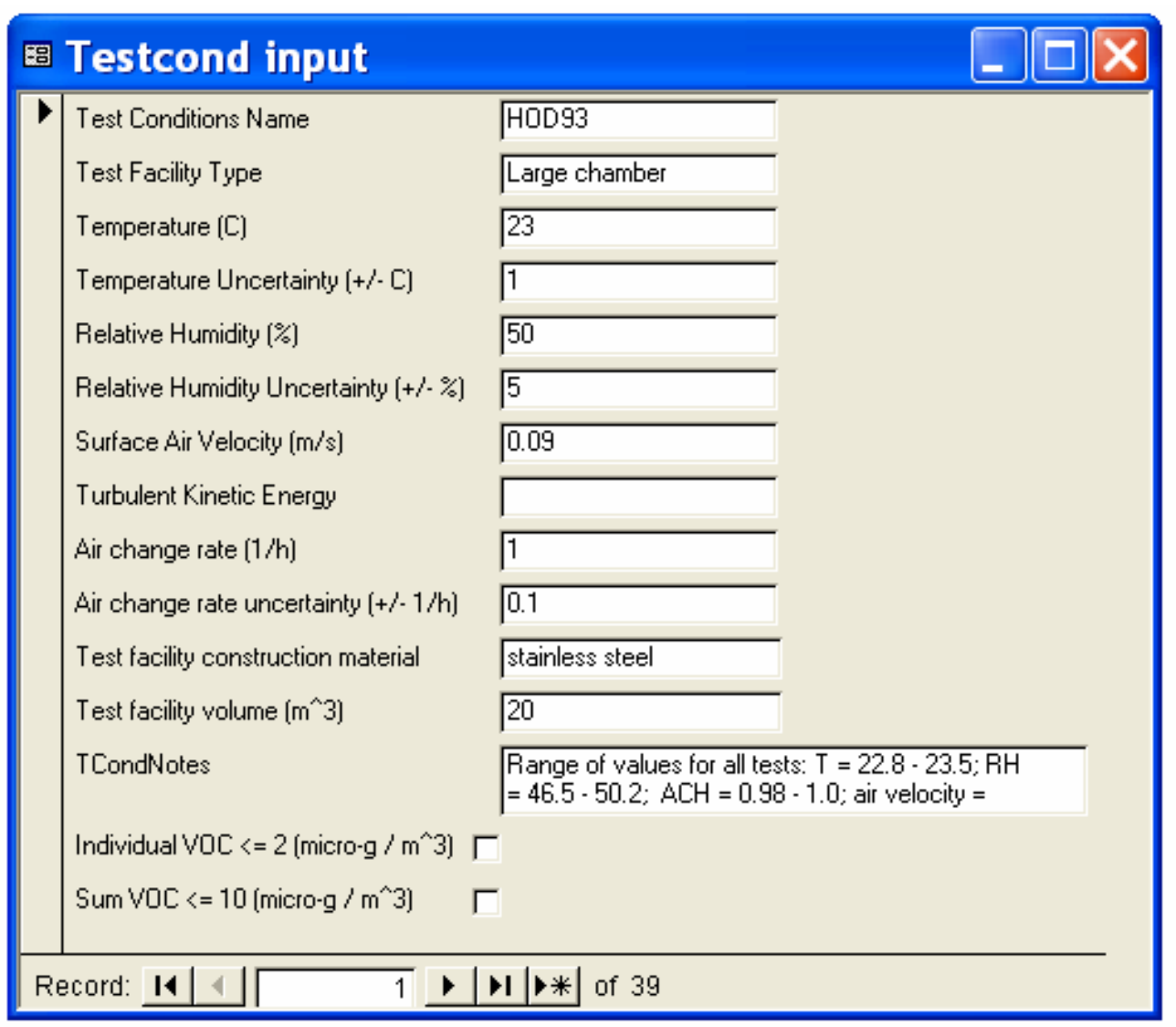

Table Name: Testcond

\begin{tabular}{|c|c|c|c|}
\hline Data Field & Field Description & Data Type & Units \\
\hline Test Conditions Name & Same as reference abbreviation & Text & \\
\hline Test Facility Type & Description of test facility & Text & \\
\hline Temperature & Temperature of test facility air & Number & ${ }^{\circ} \mathrm{C}$ \\
\hline Temperature Uncertainty & Uncertainty of temperature measurement & Number & $\pm{ }^{\circ} \mathrm{C}$ \\
\hline Relative Humidity & Relative Humidity of test facility air & Number & $\%$ \\
\hline $\begin{array}{l}\text { Relative Humidity } \\
\text { Uncertainty }\end{array}$ & Uncertainty of relative humidity measurement & Number & $\pm \%$ \\
\hline Surface Air Velocity & Air velocity in test facility near sample surface & Number & $\mathrm{m} / \mathrm{s}$ \\
\hline Turbulent Kinetic Energy & Turbulent kinetic energy of test facility air & Number & \\
\hline Air change rate & Air change rate of test facility & Number & $1 / \mathrm{h}$ \\
\hline $\begin{array}{l}\text { Air change rate } \\
\text { uncertainty }\end{array}$ & Uncertainty of air change rate measurement & Number & $\pm 1 / \mathrm{h}$ \\
\hline $\begin{array}{l}\text { Test facility construction } \\
\text { material }\end{array}$ & $\begin{array}{l}\text { Material covering test facility walls, ceiling and } \\
\text { floor }\end{array}$ & Text & \\
\hline Test facility volume & Volume of air in test facility & Number & $\mathrm{m}^{3}$ \\
\hline TCondNotes & $\begin{array}{l}\text { Clarifying and additional information regarding } \\
\text { test conditions }\end{array}$ & Text & \\
\hline $\begin{array}{l}\text { Individual VOCs } \leq 2 \\
\mu \mathrm{g} / \mathrm{m}^{3}\end{array}$ & $\begin{array}{l}\text { Is concentration of each VOC measured in } \\
\text { background air of test facility less than or equal } \\
\text { to } 2 \mu \mathrm{g} / \mathrm{m}^{3} \text { ? }\end{array}$ & $\mathrm{Yes} / \mathrm{No}$ & \\
\hline Sum VOCs $\leq 10 \mu \mathrm{g} / \mathrm{m}^{3}$ & $\begin{array}{l}\text { Is concentration of all VOCs measured in } \\
\text { background air of test facility less than or equal } \\
\text { to } 10 \mu \mathrm{g} / \mathrm{m}^{3} \text { ? }\end{array}$ & Yes/No & \\
\hline
\end{tabular}




\section{国 Equation Input}

$\checkmark$

Description

NoDfCoef

Coefficient 1

Coefficient 2

Coefficient 3

Coefficient 4

Source Model Type Constant Coefficient
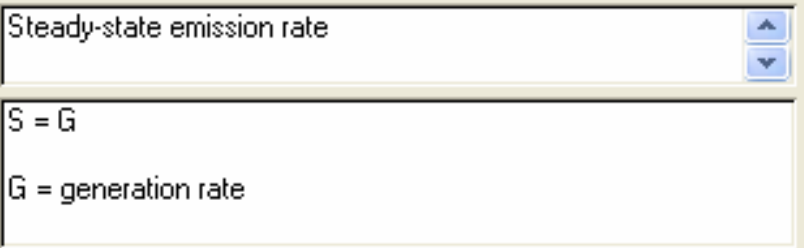

Record:

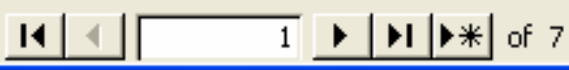

Table Name: Equation

\begin{tabular}{|l|l|c|c|}
\hline Data Field & Field Description & Data Type & Units \\
\hline Description & Description of emissions model & Text & \\
\hline Equation & Model equations with definition of coefficients & Text & \\
\hline NoOfCoef & Number of model coefficients & Number & \\
\hline Coefficient 1 & Parameter defined as model coefficient 1 & Text & \\
\hline Coefficient 2 & Parameter defined as model coefficient 2 & Text & \\
\hline Coefficient 3 & Parameter defined as model coefficient 3 & Text & \\
\hline Coefficient 4 & Parameter defined as model coefficient 4 & Text & \\
\hline Source Model Type & CONTAM Name of source model & Text & \\
\hline
\end{tabular}

\section{国 Propertylnput}

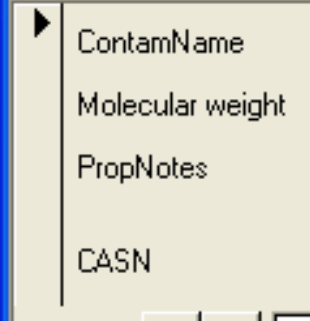

1,2-Dichlorobenzene

147

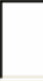

$95-50-1$

Record: I4

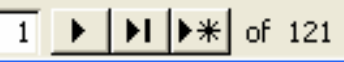

Table Name: Property

\begin{tabular}{|l|l|c|c|}
\hline Data Field & Field Description & Data Type & Units \\
\hline ContamName & Name of contaminant & Text & \\
\hline Molecular weight & Molecular weight of contaminant & Number & \\
\hline PropNotes & $\begin{array}{l}\text { Clarifying or additional information regarding the } \\
\text { contaminant }\end{array}$ & Text & \\
\hline CASN & Chemical Abstract Service Number & & \\
\hline
\end{tabular}




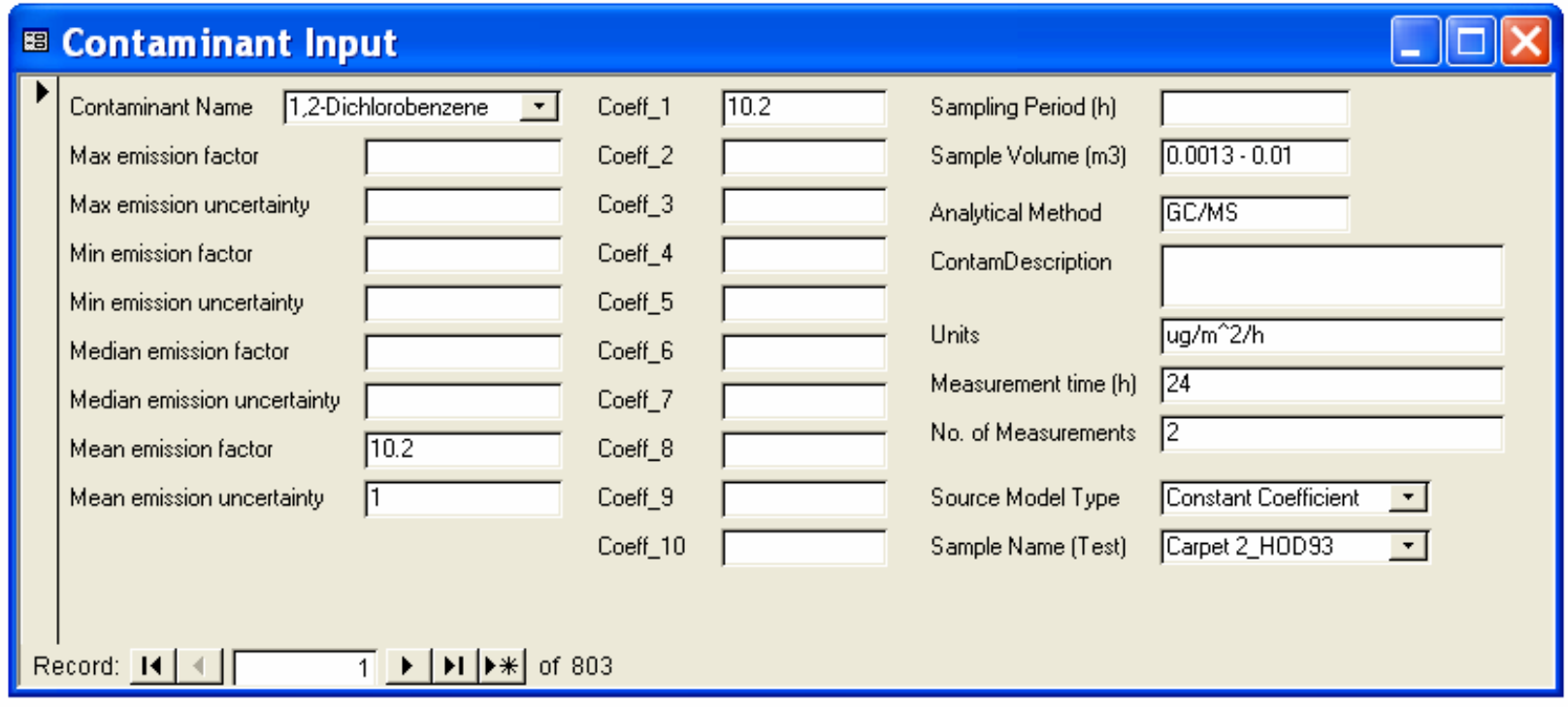

Table Name: Contaminant

\begin{tabular}{|c|c|c|c|}
\hline Data Field & Field Description & Data Type & Units \\
\hline Contaminant Name & Link to contaminant name & Text & \\
\hline Max emission factor & Maximum emission rate for sample period & Number & \\
\hline $\begin{array}{l}\text { Max emission } \\
\text { uncertainty }\end{array}$ & $\begin{array}{l}\text { Uncertainty of maximum emission rate } \\
\text { measurement }\end{array}$ & Number & \\
\hline Min emission factor & Minimum emission rate for sample period & Number & \\
\hline $\begin{array}{l}\text { Min emission } \\
\text { uncertainty }\end{array}$ & $\begin{array}{l}\text { Uncertainty of minimum emission rate } \\
\text { measurement }\end{array}$ & Number & \\
\hline $\begin{array}{l}\text { Median emission } \\
\text { factor }\end{array}$ & Median emission rate for given sample time & Number & \\
\hline $\begin{array}{l}\text { Median emission } \\
\text { uncertainty }\end{array}$ & $\begin{array}{l}\text { Uncertainty of median emission rate } \\
\text { measurement }\end{array}$ & Number & \\
\hline Mean emission factor & Mean emission rate for given sample time & Number & \\
\hline $\begin{array}{l}\text { Mean emission } \\
\text { uncertainty }\end{array}$ & $\begin{array}{l}\text { Uncertainty of mean emission rate } \\
\text { measurement }\end{array}$ & Number & \\
\hline Coeff_1 & Value of model coefficient 1 & Number & \\
\hline Coeff_2 & Value of model coefficient 2 & Number & \\
\hline Coeff 3 & Value of model coefficient 3 & Number & \\
\hline Coeff_ 4 & Value of model coefficient 4 & Number & \\
\hline Coeff_5-Coeff_10 & $\begin{array}{l}\text { Value of model coefficients } 5-10 \text {, if } \\
\text { necessary }\end{array}$ & Number & \\
\hline Sampling Period & The length of time sample was collected & Text & $\mathrm{h}$ \\
\hline Sample Volume & Volume of sample collected & Text & $\mathrm{m}^{3}$ \\
\hline Analytical Method & Detector used to measure concentration & Text & \\
\hline Contam Description & $\begin{array}{l}\text { Clarifying or additional information } \\
\text { regarding emission rate data }\end{array}$ & Text & \\
\hline Units & Units of coefficients listed in order & Text & \\
\hline Measurement time & Time sample was collected & Text & $\mathrm{h}$ \\
\hline No. of Measurements & $\begin{array}{l}\text { Number of samples included in reported } \\
\text { emission factor }\end{array}$ & Text & \\
\hline Source Model Type & Link to source model & Number & \\
\hline Sample Name (Test) & Link to test conditions & Number & \\
\hline
\end{tabular}




\section{Combustion Source Emission Rate Data Entry Forms}

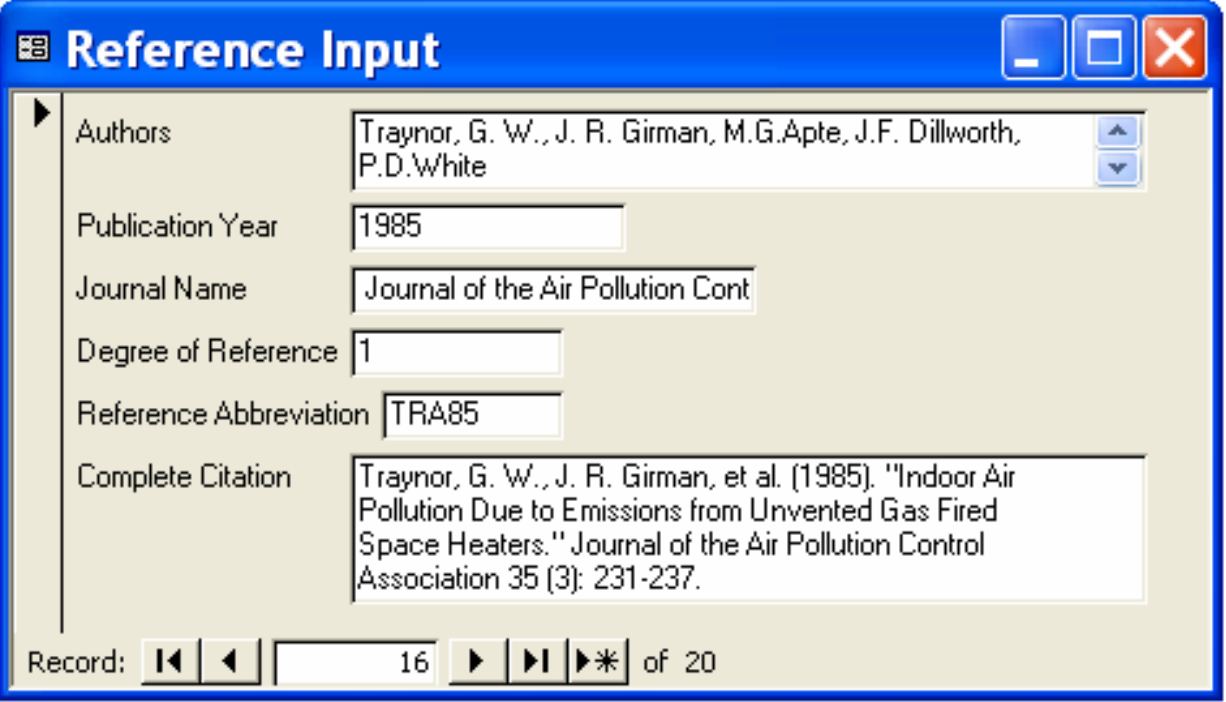

\begin{tabular}{|c|c|c|c|}
\hline Data Field & Field Description & Data Type & Units \\
\hline Authors & Authors of reference & Text & \\
\hline Publication Year & Year reference was published & Text & \\
\hline Journal Name & $\begin{array}{l}\text { Title of journal or other document where reference } \\
\text { was published }\end{array}$ & Text & \\
\hline Degree of Reference & $\begin{array}{l}\text { Reflects peer review status of reference. For example, } \\
\text { a } 1^{\text {st }} \text { degree reference indicates journal level review, } \\
2^{\text {nd }} \text { degree reference indicates conference level } \\
\text { review, and } 3^{\text {rd }} \text { degree reference indicates internal } \\
\text { review. }\end{array}$ & Number & \\
\hline $\begin{array}{l}\text { Reference } \\
\text { Abbreviation }\end{array}$ & $\begin{array}{l}\text { Consists of the first three letters of the first author's } \\
\text { last name and abbreviated year of publication. }\end{array}$ & Text & \\
\hline Complete citation & Complete citation for reference & Text & \\
\hline
\end{tabular}




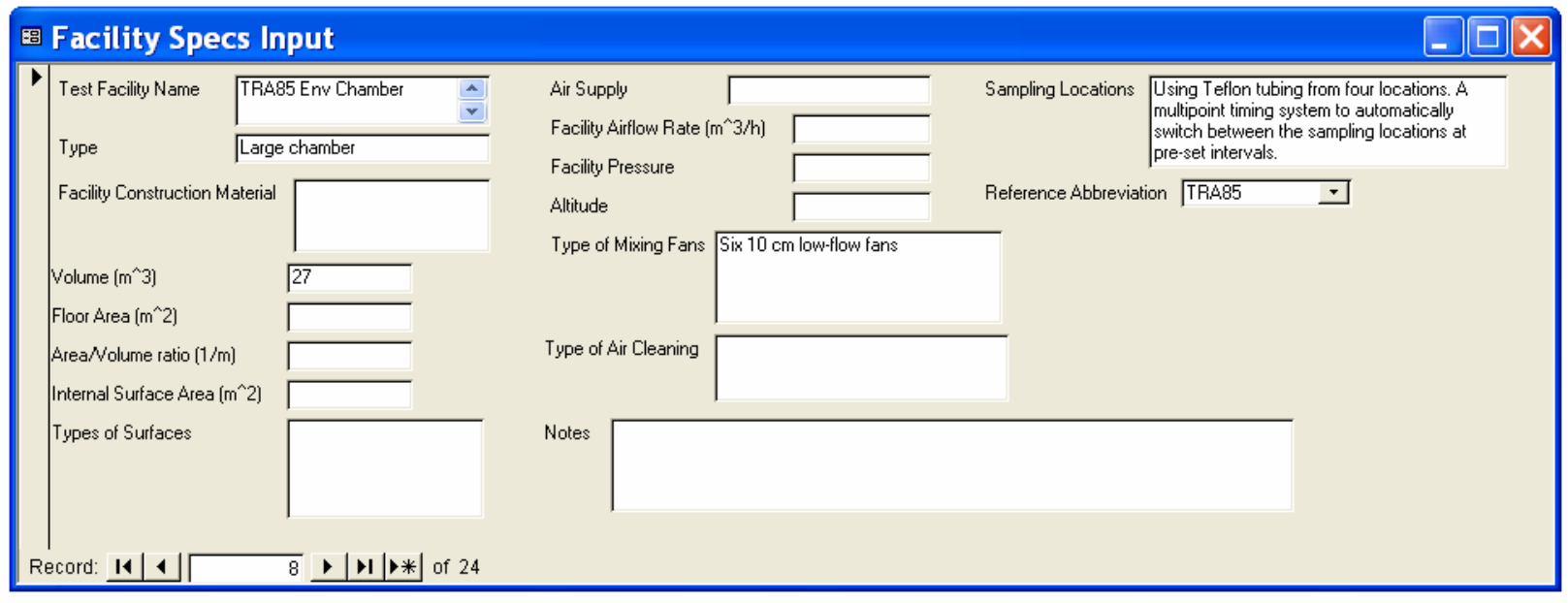

\begin{tabular}{|c|c|c|c|}
\hline Data Field & Field Description & Data Type & Units \\
\hline Test Facility Name & $\begin{array}{l}\text { Reference Abbreviation with internal descriptor of } \\
\text { test facility }\end{array}$ & Text & \\
\hline Type & Type of test facility & Text & \\
\hline $\begin{array}{l}\text { Facility Construction } \\
\text { Material }\end{array}$ & Material covering test facility walls, ceiling and floor & Text & \\
\hline Volume & Volume of air in test facility & Number & $\mathrm{m}^{3}$ \\
\hline Floor Area & Surface area of test facility floor & Number & $\mathrm{m}^{2}$ \\
\hline Area/Volume ratio & $\begin{array}{l}\text { Surface area of test facility to volume of test facility } \\
\text { ratio }\end{array}$ & Number & $\mathrm{m}^{2} / \mathrm{m}^{3}$ \\
\hline $\begin{array}{l}\text { Internal Surface } \\
\text { Area }\end{array}$ & Surface area of test facility walls, ceiling and floor & Number & $\mathrm{m}^{2}$ \\
\hline Type of Surfaces & $\begin{array}{l}\text { Description of surfaces in test facility, in addition to } \\
\text { walls, ceiling and floor }\end{array}$ & Text & \\
\hline Air Supply & Source of air added to test facility & Text & \\
\hline $\begin{array}{l}\text { Facility Airflow } \\
\text { Rate }\end{array}$ & Airflow rate measured in test facility & Number & $\mathrm{m}^{3} / \mathrm{h}$ \\
\hline Facility Pressure & Air pressure measured in test facility & Text & \\
\hline Altitude & Altitude of test facility & Text & \\
\hline Type of Mixing Fans & Description of mixing fans in test facility & Text & \\
\hline $\begin{array}{l}\text { Type of Air } \\
\text { Cleaning }\end{array}$ & $\begin{array}{l}\text { Description of filtration/air cleaning devices used in } \\
\text { test facility }\end{array}$ & Text & \\
\hline Notes & $\begin{array}{l}\text { Clarifying or additional information regarding test } \\
\text { facility }\end{array}$ & Text & \\
\hline Sampling Locations & Description of sample locations in test facility & Text & \\
\hline $\begin{array}{l}\text { Reference } \\
\text { Abbreviation }\end{array}$ & Link to reference abbreviation & Number & \\
\hline
\end{tabular}




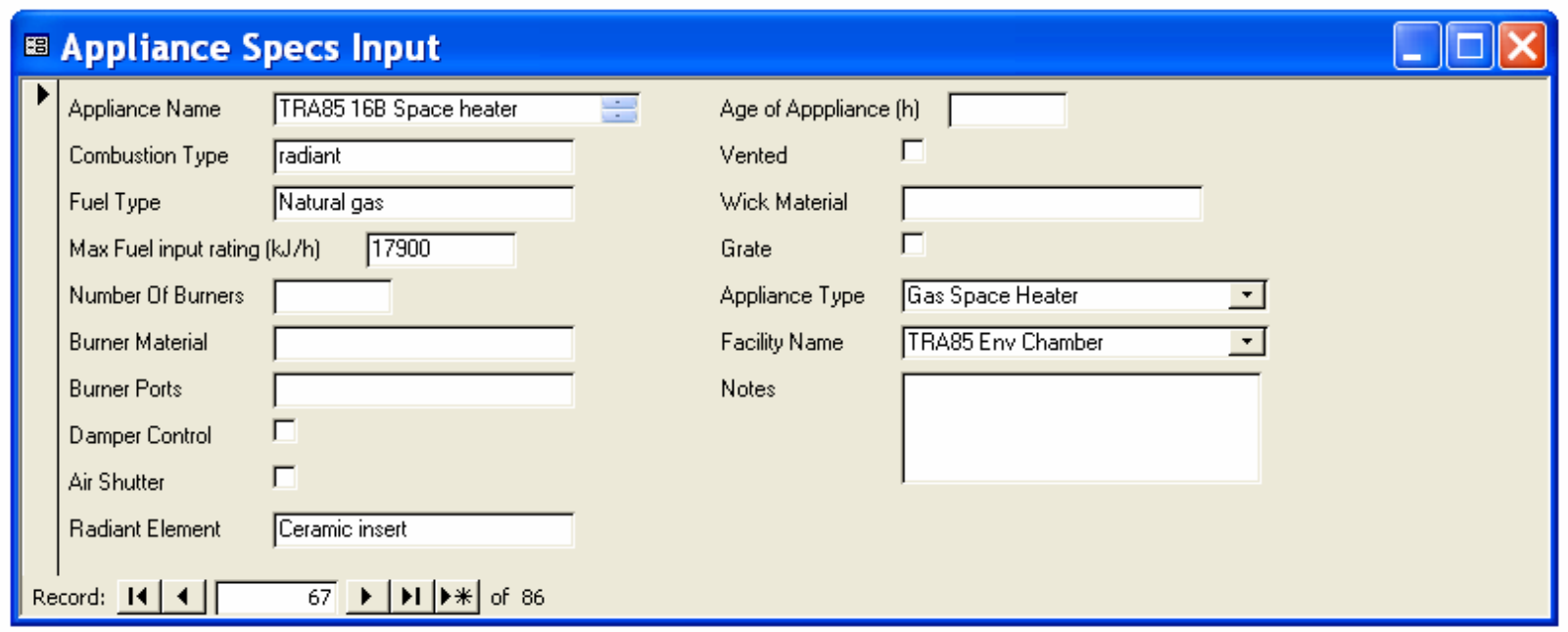

\begin{tabular}{|l|l|c|c|}
\hline Data Field & Field Description & Data Type & Units \\
\hline Appliance Name & $\begin{array}{l}\text { Reference abbreviation and internal appliance } \\
\text { descriptor }\end{array}$ & Text & \\
\hline Combustion Type & Combustion mechanism & Text & \\
\hline Fuel Type & Fuel used in appliance & Number & $\mathrm{kJ} / \mathrm{h}$ \\
\hline $\begin{array}{l}\text { Max Fuel input } \\
\text { rating }\end{array}$ & Maximum fuel input rating for appliance & Number & \\
\hline Number of Burners & Number of burners operated during test & Text & \\
\hline Burner Material & Material of burners used in test & Text & \\
\hline Burner Ports & Type of burner port in appliance & Yes/No & \\
\hline Damper Control & Does the appliance have damper control? & Yes/No & \\
\hline Air Shutter & Does the appliance have an air shutter? & Text & \\
\hline Radiant Element & Type of radiant element & Number & $\mathrm{h}$ \\
\hline Age of Appliance & Appliance age at time of test & Yes/No & \\
\hline Vented & Is the appliance vented? & Text & \\
\hline Wick Material & Type of candle wick & Yes/No & \\
\hline Grate & Does the appliance have a grate? & Number & \\
\hline Appliance Type & Link to appliance type & Number & \\
\hline Facility Name & Link to facility name & Text & \\
\hline Notes & $\begin{array}{l}\text { Clarifying or additional information regarding } \\
\text { appliance specifications }\end{array}$ & & \\
\hline
\end{tabular}




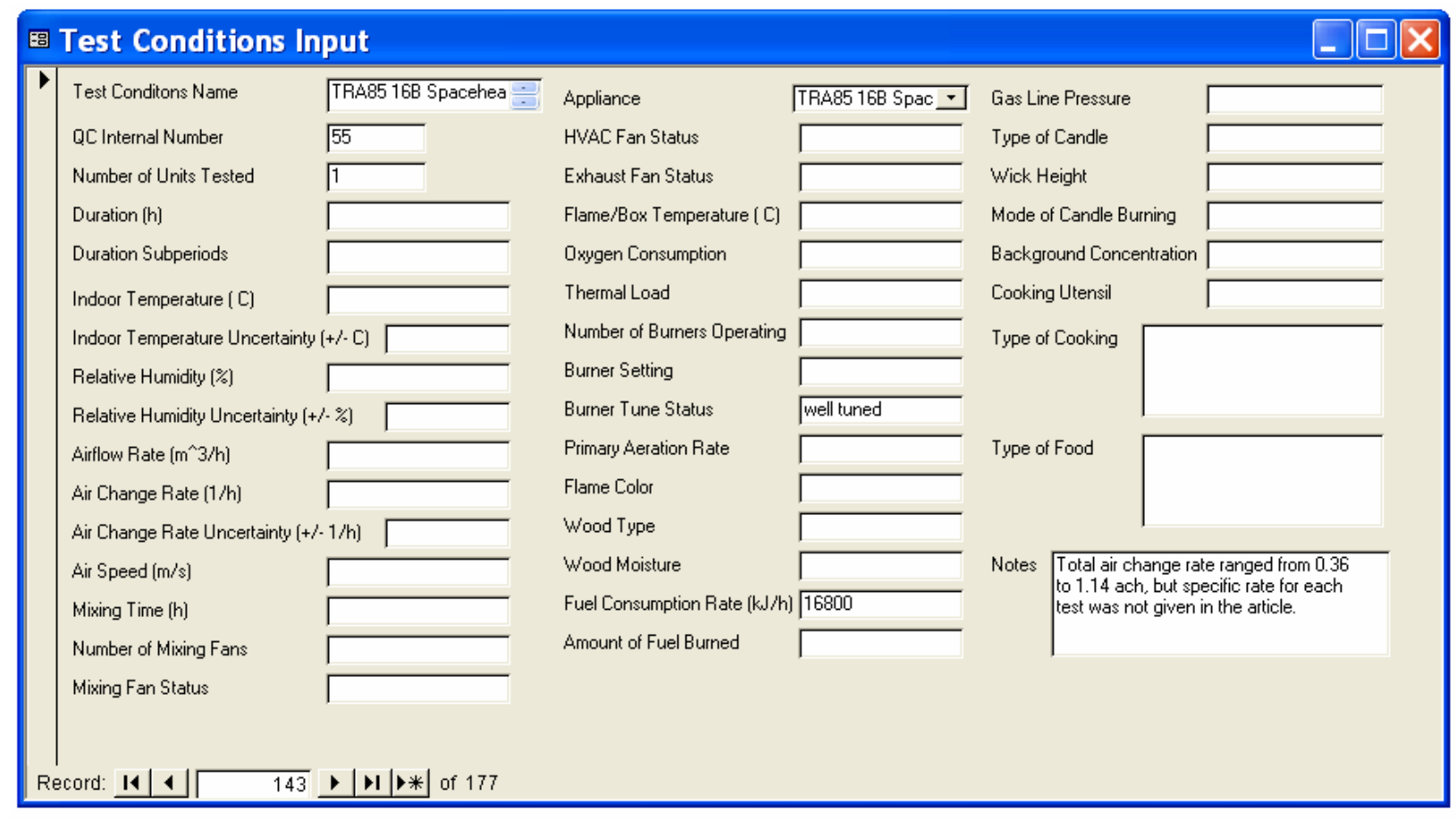

\begin{tabular}{|c|c|c|c|}
\hline Data Field & Field Description & Data Type & Units \\
\hline Test Conditions Name & Reference ID and internal descriptor & Text & \\
\hline QC Internal Number & $\begin{array}{l}\text { Internal record keeping number for quality } \\
\text { assurance checks }\end{array}$ & Number & \\
\hline Number of Units Tested & $\begin{array}{l}\text { Number of appliances tested for given emission } \\
\text { factor }\end{array}$ & Number & \\
\hline Duration & Length of experiment & Text & $\mathrm{h}$ \\
\hline Duration Subperiods & Any distinction of experiment time periods & Text & \\
\hline Indoor Temperature & Temperature of room air in test facility & Number & ${ }^{\circ} \mathrm{C}$ \\
\hline $\begin{array}{l}\text { Indoor Temperature } \\
\text { Uncertainty }\end{array}$ & Uncertainty of temperature measurement & Number & $\pm{ }^{\circ} \mathrm{C}$ \\
\hline Relative Humidity & Relative humidity of test facility & Number & $\%$ \\
\hline $\begin{array}{l}\text { Relative Humidity } \\
\text { Uncertainty }\end{array}$ & Uncertainty of relative humidity measurement & Number & $\pm \%$ \\
\hline Airflow Rate & Flow rate of air through test facility & Number & $\mathrm{m}^{3} / \mathrm{h}$ \\
\hline Air Change Rate & Volumetric air change rate of test facility & Number & $1 / \mathrm{h}$ \\
\hline $\begin{array}{l}\text { Air Change Rate } \\
\text { Uncertainty }\end{array}$ & Uncertainty of air change rate measurement & Number & $\pm 1 / \mathrm{h}$ \\
\hline Air Speed & Velocity of air near surface of test appliance & Number & $\mathrm{m} / \mathrm{s}$ \\
\hline Mixing Time & Period of mixing prior to first sample & Number & $\mathrm{h}$ \\
\hline Number of Mixing Fans & Number of mixing fans in test facility & Number & \\
\hline Mixing Fan Status & Description of mixing fan use during the test & Text & \\
\hline Appliance & Link to appliance name & Number & \\
\hline HVAC Fan Status & Description of facility HVAC use during the test & Text & \\
\hline Exhaust Fan Status & $\begin{array}{l}\text { Description of facility exhaust fan use during the } \\
\text { test }\end{array}$ & Text & \\
\hline Flame/Box Temperature & $\begin{array}{l}\text { Temperature of heated chamber (e.g., fire box, } \\
\text { oven, etc.) }\end{array}$ & Number & ${ }^{\circ} \mathrm{C}$ \\
\hline
\end{tabular}




\begin{tabular}{|l|l|c|c|}
\hline Oxygen Consumption & Appliance oxygen consumption rate & Text & \\
\hline Thermal Load & Thermal load of appliance & Number & \\
\hline $\begin{array}{l}\text { Number of Burners } \\
\text { Operating }\end{array}$ & Number of burners on during the test & Text & \\
\hline Burner Setting & $\begin{array}{l}\text { Level of burner setting according to appliance } \\
\text { (e.g., low, medium, high) }\end{array}$ & Text & \\
\hline Burner Tune Status & How well-tuned are the appliance burners & Text & \\
\hline Primary Aeration Rate & Allowance of primary air to appliance & Text & \\
\hline Flame Color & Color of appliance flame & Text & \\
\hline Wood Type & Type of wood burned & Text & \\
\hline Wood Moisture & Moisture content of wood burned & Number & $\mathrm{kJ} / \mathrm{h}$ \\
\hline Fuel Consumption Rate & Rate of fuel consumption for appliance & Text & \\
\hline Amount of Fuel Burned & Mass of fuel burned for test & Text & \\
\hline Gas Line Pressure & Pressure of gas in input line & Text & \\
\hline Type of Candle & Type of candle burned for test & Text & \\
\hline Wick Height & Height of candle wick & Text & \\
\hline Mode of Candle Burning & Description of candle burn (e.g, sooting, etc.) & Text & \\
\hline $\begin{array}{l}\text { Background } \\
\text { Concentration }\end{array}$ & Room air concentration in test facility prior to test & Text & \\
\hline Cooking Utensil & Type of utensil used in cooking test & Text & \\
\hline Type of Cooking & Description of cooking style for test & Text & \\
\hline Type of Food & Description of food cooked during test & Text & \\
\hline Notes & $\begin{array}{l}\text { Clarifying or additional information regarding } \\
\text { test conditions }\end{array}$ & & \\
\hline
\end{tabular}




\section{凅 Equation Input}

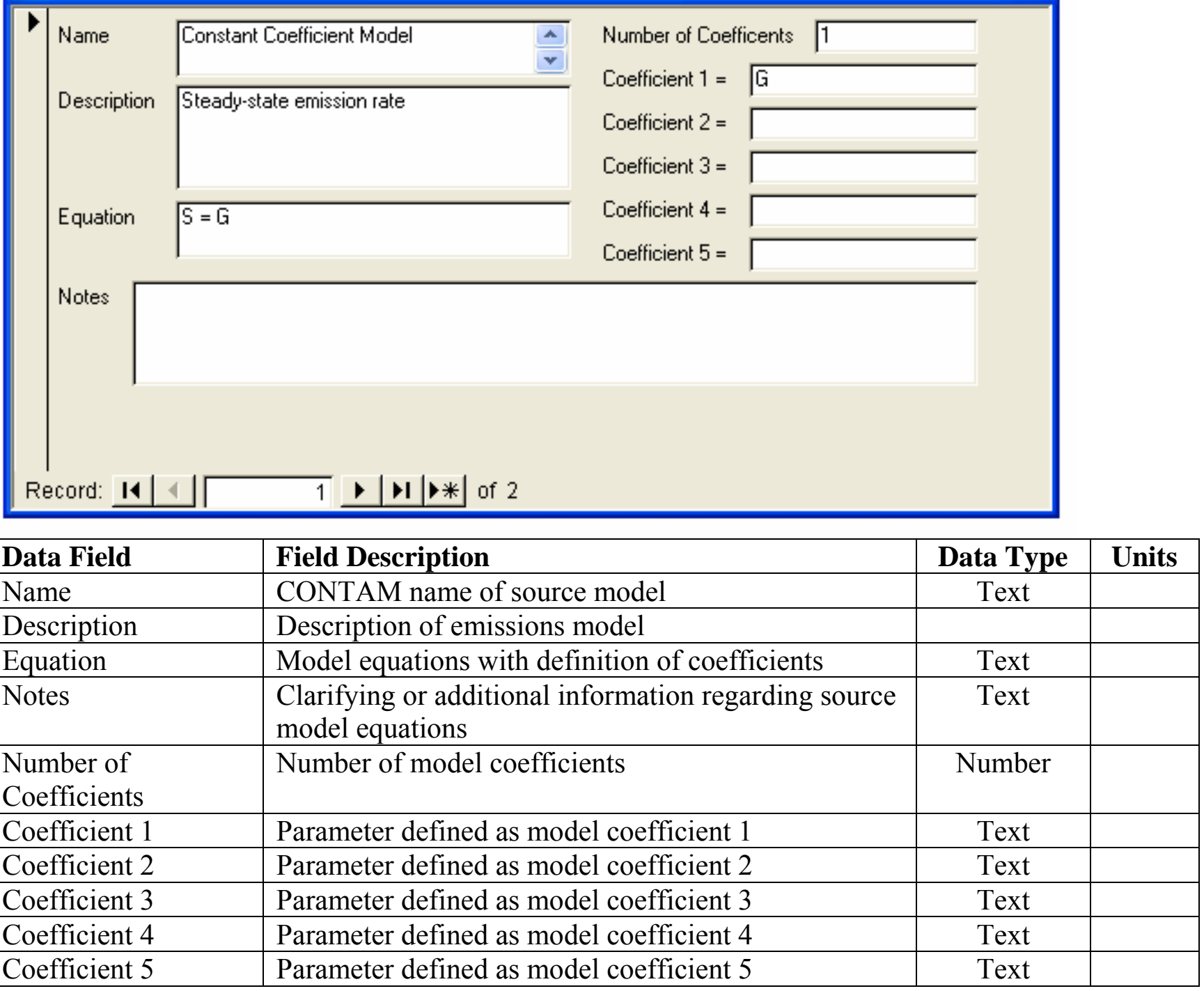




\section{国 Contam Properties Input}

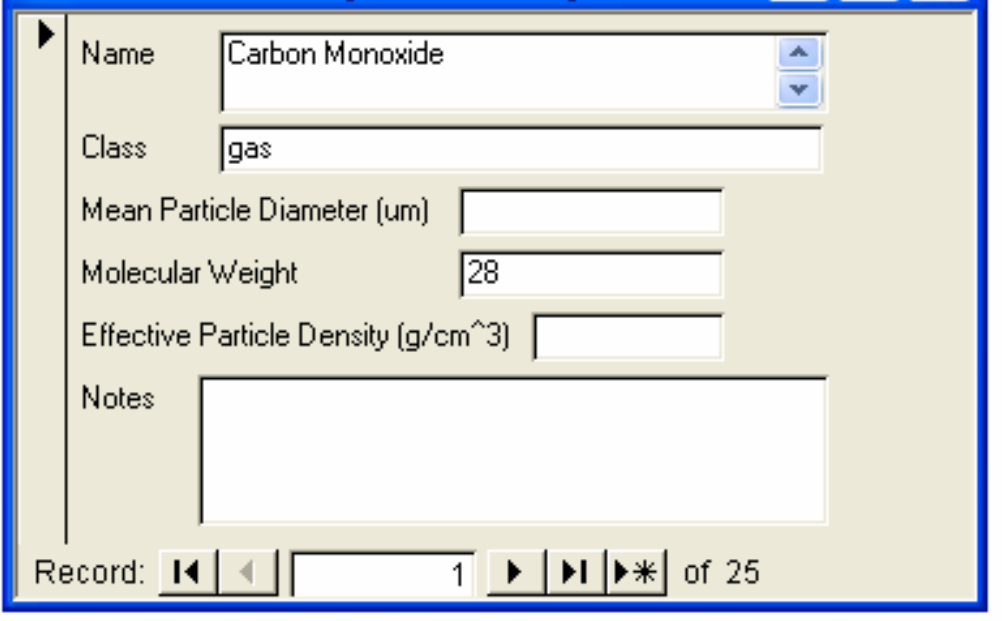

\begin{tabular}{|l|l|c|c|}
\hline Data Field & Field Description & Data Type & Units \\
\hline Name & Name of contaminant & Text & \\
\hline Class & Physical state of contaminant & Text & \\
\hline $\begin{array}{l}\text { Mean Particle } \\
\text { Diameter }\end{array}$ & Mean diameter of particle measured & Number & $\mu \mathrm{m}$ \\
\hline Molecular Weight & Molecular weight of contaminant & Text & \\
\hline $\begin{array}{l}\text { Effective Particle } \\
\text { Density }\end{array}$ & Effective density of particle & Number & $\mathrm{g} / \mathrm{cm}^{3}$ \\
\hline Notes & $\begin{array}{l}\text { Clarifying or additional information regarding } \\
\text { contaminant properties }\end{array}$ & Text & \\
\hline
\end{tabular}




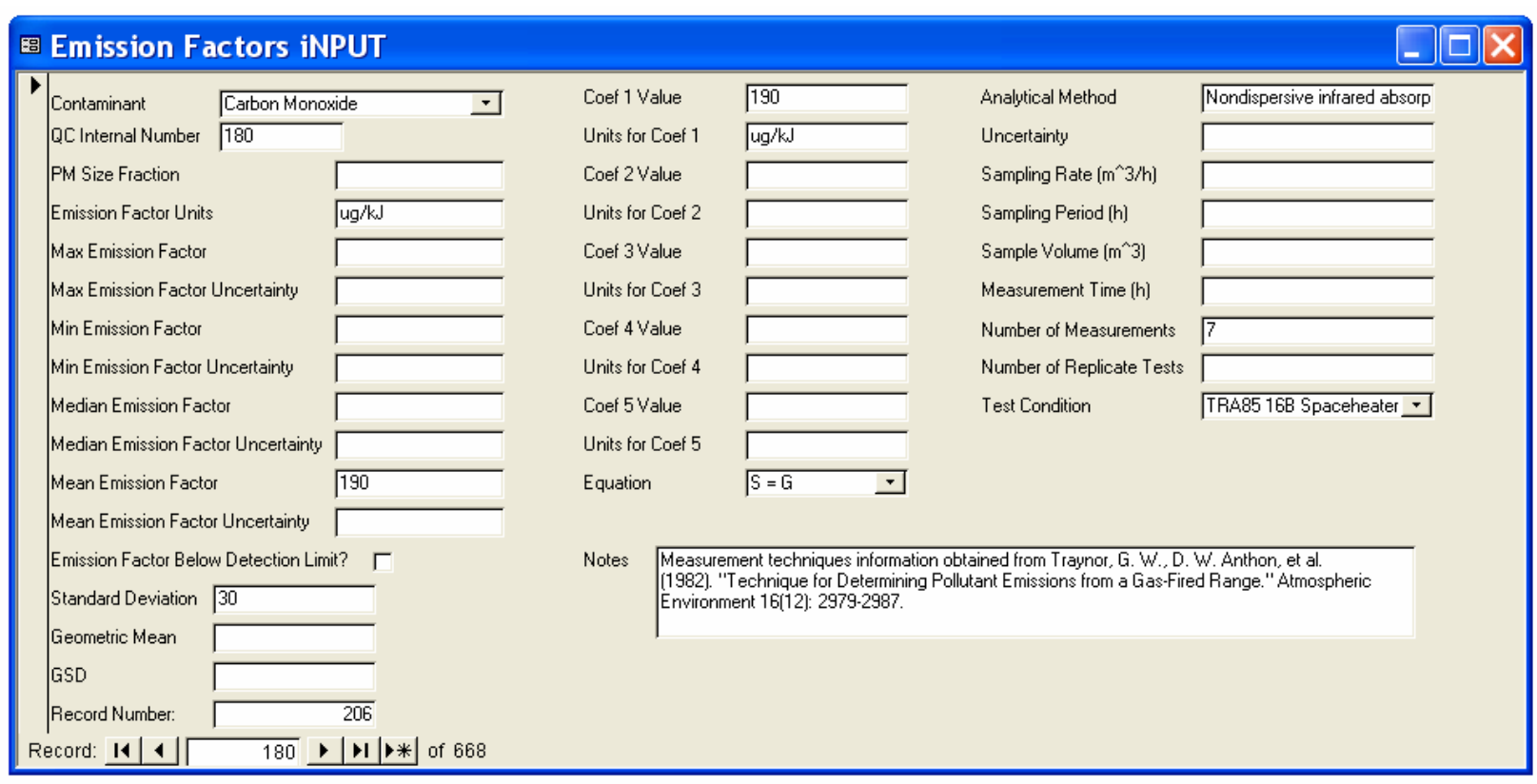

\begin{tabular}{|c|c|c|c|}
\hline Data Field & Field Description & Data Type & Units \\
\hline Contaminant & Link to contaminant ID & Number & \\
\hline QC Internal Number & $\begin{array}{l}\text { Internal record keeping number for quality } \\
\text { assurance checks }\end{array}$ & Number & \\
\hline PM Size Fraction & $\begin{array}{l}\text { Range of particle diameters for given emission } \\
\text { factor }\end{array}$ & Text & \\
\hline Emission Factor Units & Units of reported emission factors & Text & \\
\hline Max Emission Factor & Maximum emission rate for sample period & Number & \\
\hline $\begin{array}{l}\text { Max Emission Factor } \\
\text { Uncertainty }\end{array}$ & $\begin{array}{l}\text { Uncertainty of maximum emission rate } \\
\text { measurement }\end{array}$ & Number & \\
\hline Min Emission Factor & Minimum emission rate for sample period & Number & \\
\hline $\begin{array}{l}\text { Min Emission Factor } \\
\text { Uncertainty }\end{array}$ & $\begin{array}{l}\text { Uncertainty of minimum emission rate } \\
\text { measurement }\end{array}$ & Number & \\
\hline Median Emission Factor & Median emission rate for sample period & Number & \\
\hline $\begin{array}{l}\text { Median Emission Factor } \\
\text { Uncertainty }\end{array}$ & $\begin{array}{l}\text { Uncertainty of minimum emission rate } \\
\text { measurement }\end{array}$ & Number & \\
\hline Mean Emission Factor & Mean emission rate for sample period & Number & \\
\hline $\begin{array}{l}\text { Mean Emission Factor } \\
\text { Uncertainty }\end{array}$ & Uncertainty of mean emission rate measurement & Number & \\
\hline $\begin{array}{l}\text { Emission Factor Below } \\
\text { Detection Limit? }\end{array}$ & $\begin{array}{l}\text { Are the measured concentrations less than the } \\
\text { minimum detection limit? }\end{array}$ & Yes/No & \\
\hline Standard Deviation & $\begin{array}{l}\text { Standard deviation of mean emission rate for } \\
\text { sample period }\end{array}$ & Number & \\
\hline Geometric Mean & Geometric mean emission rate for sample period & Number & \\
\hline GSD & $\begin{array}{l}\text { Geometric standard deviation of emission rate for } \\
\text { sample period }\end{array}$ & Number & \\
\hline Record Number & Database automatic record number & Autonumber & \\
\hline Coef 1 Value & Value of first coefficient in model equation & Number & \\
\hline Units for Coef 1 & Units of first coefficient in model & Text & \\
\hline Coef 2 Value & Value of second coefficient in model equation & Number & \\
\hline Units for Coef 2 & Units of second coefficient in model & Text & \\
\hline
\end{tabular}




\begin{tabular}{|c|c|c|c|}
\hline Coef 3 Value & Value of third coefficient in model equation & Number & \\
\hline Units for Coef 3 & Units of third coefficient in model & Text & \\
\hline Coef 4 Value & Value of fourth coefficient in model equation & Number & \\
\hline Units for Coef 4 & Units of fourth coefficient in model & Text & \\
\hline Coef 5 Value & Value of fifth coefficient in model equation & Number & \\
\hline Units for Coef 5 & Units of fifth coefficient in model & Text & \\
\hline Equation & Link to equation ID & Number & \\
\hline Notes & $\begin{array}{l}\text { Clarifying or additional information regarding the } \\
\text { emission rate measurements }\end{array}$ & Text & \\
\hline Analytical Method & $\begin{array}{l}\text { Instrument used to measure contaminant } \\
\text { concentrations }\end{array}$ & Text & \\
\hline Uncertainty & $\begin{array}{l}\text { Uncertainty of analytical method used to measure } \\
\text { contaminant concentrations }\end{array}$ & Text & \\
\hline Sampling Rate & Volumetric airflow sample rate of instrument & Number & $\mathrm{m}^{3} / \mathrm{h}$ \\
\hline Sampling Period & Duration of sample collection & Text & \\
\hline Sample Volume & Air volume of sample collected & Number & $\mathrm{m}^{3}$ \\
\hline Measurement Time & Time sample was collected & Text & \\
\hline $\begin{array}{l}\text { Number of } \\
\text { Measurements }\end{array}$ & $\begin{array}{l}\text { Number of samples collected for emission rate } \\
\text { estimate }\end{array}$ & Number & \\
\hline $\begin{array}{l}\text { Number of Replicate } \\
\text { Tests }\end{array}$ & $\begin{array}{l}\text { Number of replicate experiments included in } \\
\text { emission rate estimate }\end{array}$ & Number & \\
\hline Test Condition & Link to Test Condition ID & Number & \\
\hline
\end{tabular}


Particle Deposition Rate Entry Forms

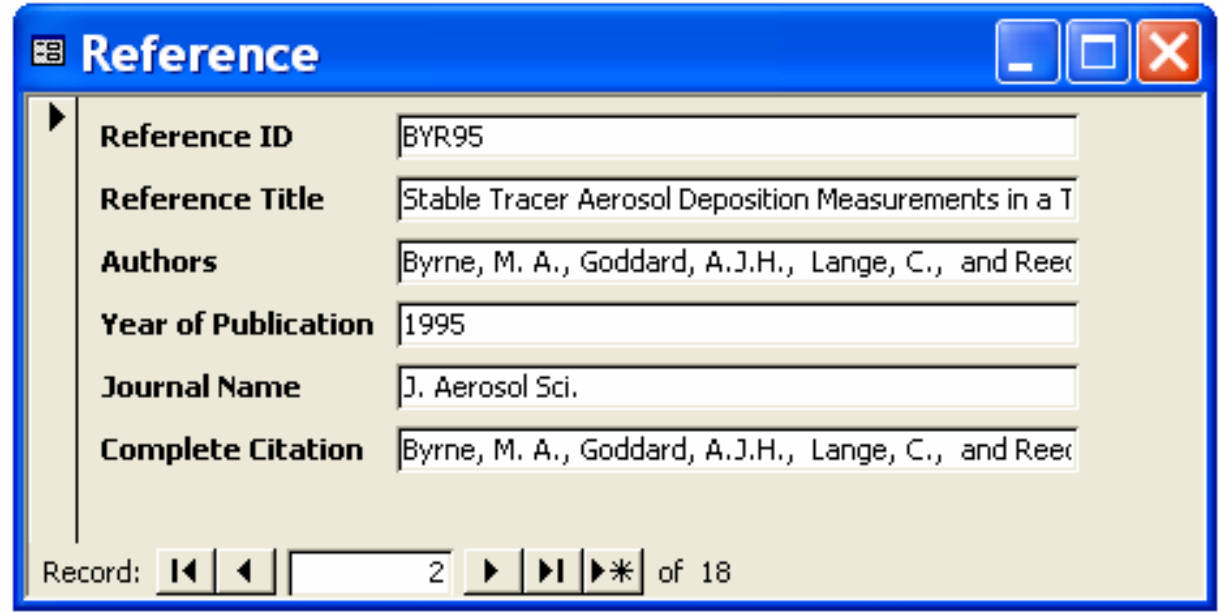

\begin{tabular}{|l|l|c|c|}
\hline Data Field & Field Description & Data Type & Units \\
\hline Reference ID & $\begin{array}{l}\text { Consists of the first three letters of the first author's } \\
\text { last name and abbreviated year of publication }\end{array}$ & Text & \\
\hline Reference Title & Title of reference & Text & \\
\hline Authors & Authors of reference & Text & \\
\hline Year of Publication & Year reference was published & Text & \\
\hline Journal Name & $\begin{array}{l}\text { Title of journal or other document where reference } \\
\text { was published }\end{array}$ & Text & \\
\hline Complete citation & Complete citation for reference &
\end{tabular}

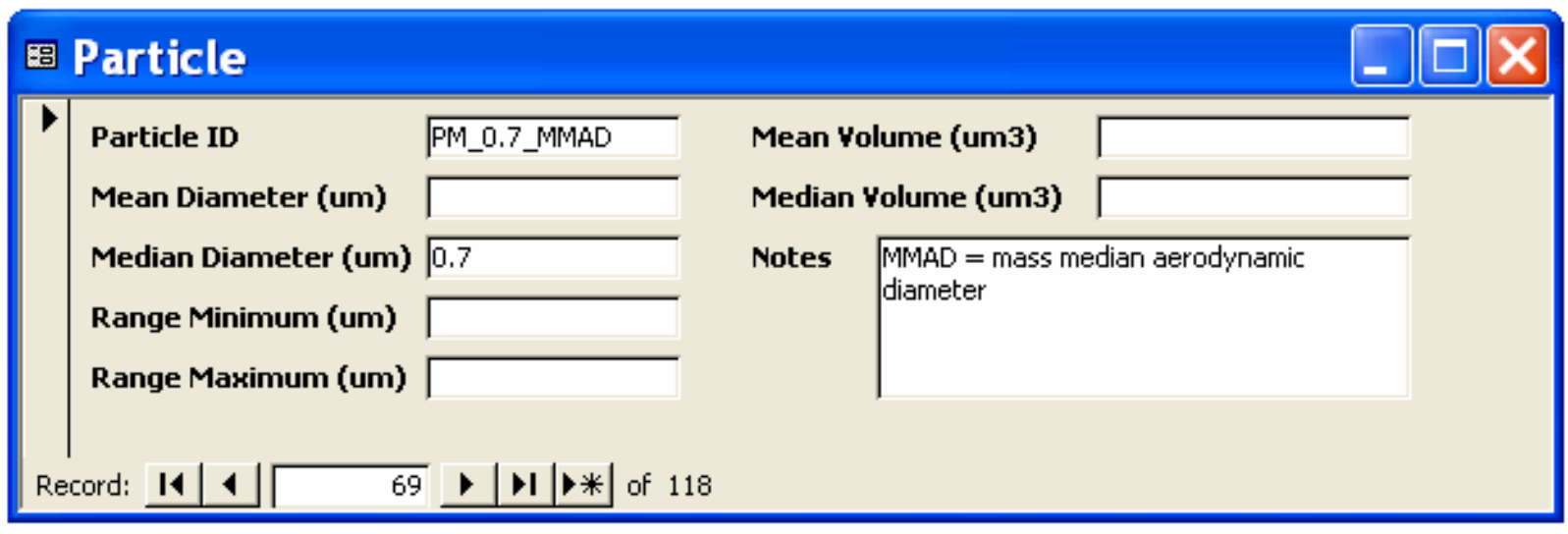

\begin{tabular}{|l|l|c|c|}
\hline Data Field & Field Description & Data Type & Units \\
\hline Particle ID & $\begin{array}{l}\text { Consists of PM_particle diameter_type of diameter } \\
\text { based on analytical method }\end{array}$ & Text & \\
\hline Mean Diameter & Mean particle diameter & Number & $\mu \mathrm{m}$ \\
\hline Median Diameter & Median particle diameter & Number & $\mu \mathrm{m}$ \\
\hline Range Minimum & Minimum particle diameter for range of sizes & Number & $\mu \mathrm{m}$ \\
\hline Range Maximum & Maximum particle diameter for range of sizes & Number & $\mu \mathrm{m}$ \\
\hline Mean Volume & Mean volume of particle & Number & $\mathrm{\mu m}^{3}$ \\
\hline Median Volume & Median volume of particle & Number & $\mathrm{\mu m}^{3}$ \\
\hline Notes & $\begin{array}{l}\text { Clarifying or additional information regarding the } \\
\text { particle properties }\end{array}$ & Text & \\
\hline
\end{tabular}




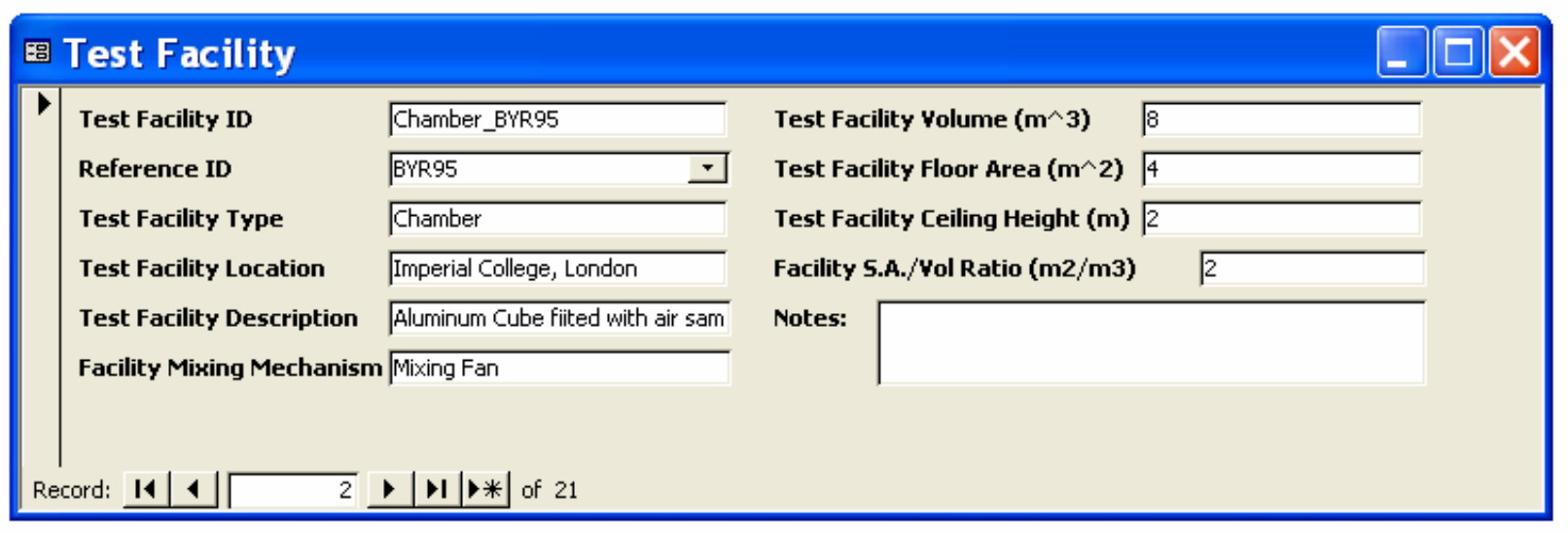

\begin{tabular}{|c|c|c|c|}
\hline Data Field & Field Description & Data Type & Units \\
\hline Test Facility ID & Test facility type and Reference ID & Text & \\
\hline Reference ID & Link to Reference ID & Number & \\
\hline Test Facility Type & Type of test facility & Text & \\
\hline $\begin{array}{l}\text { Test Facility } \\
\text { Location }\end{array}$ & Geographical location of test facility & Text & \\
\hline $\begin{array}{l}\text { Test Facility } \\
\text { Description }\end{array}$ & General description of test facility & Text & \\
\hline $\begin{array}{l}\text { Facility Mixing } \\
\text { Mechanism }\end{array}$ & Air mixing mechanisms in test facility & Text & \\
\hline Test Facility Volume & Air volume of test facility & Number & $\mathrm{m}^{3}$ \\
\hline $\begin{array}{l}\text { Test Facility Floor } \\
\text { Area }\end{array}$ & Surface area of the test facility floor & Number & $\mathrm{m}^{2}$ \\
\hline $\begin{array}{l}\text { Test Facility Ceiling } \\
\text { Height }\end{array}$ & Average height from floor to ceiling of test facility & Number & $\mathrm{m}$ \\
\hline $\begin{array}{l}\text { Facility S.A./Vol } \\
\text { Ratio }\end{array}$ & $\begin{array}{l}\text { Total surface area of the test facility to volume of test } \\
\text { facility ratio }\end{array}$ & Number & $\mathrm{m}^{2} / \mathrm{m}^{3}$ \\
\hline Notes & $\begin{array}{l}\text { Clarifying or additional information related to the test } \\
\text { facility }\end{array}$ & Text & \\
\hline
\end{tabular}




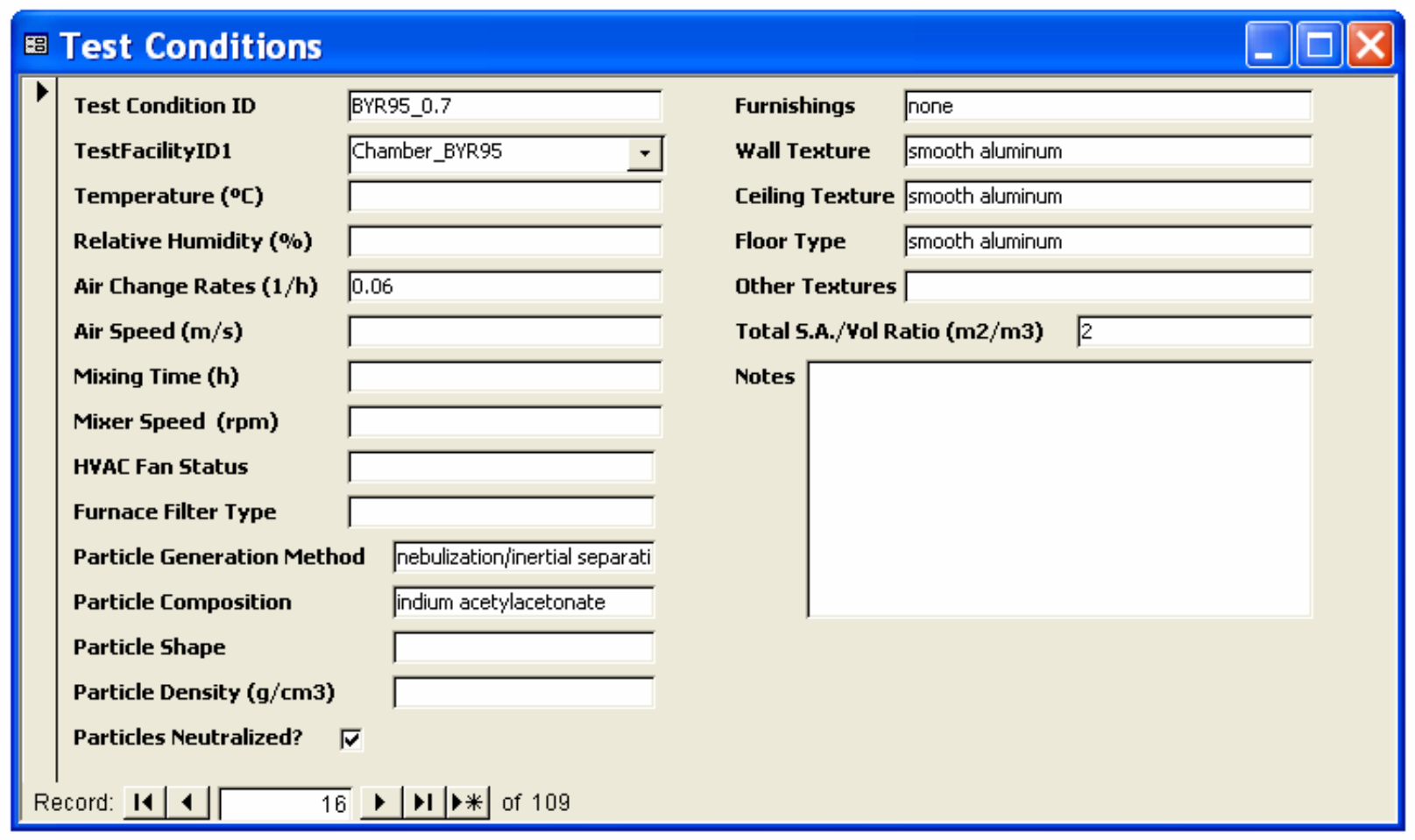

\begin{tabular}{|l|l|c|c|}
\hline Data Field & Field Description & Data Type & Units \\
\hline Test Condition ID & Reference ID and internal test condition descriptor & Text & \\
\hline TestFacilityID1 & Link to Test Facility ID & Number & \\
\hline Temperature & Air temperature in test facility & Number & ${ }^{\circ} \mathrm{C}$ \\
\hline Relative Humidity & Relative humidity of room air in test facility & Number & $\%$ \\
\hline Air Change Rates & Range of air change rates for test condition & Text & $1 / \mathrm{h}$ \\
\hline Air Speed & Room air velocity & Number & $\mathrm{m} / \mathrm{s}$ \\
\hline Mixing Time & $\begin{array}{l}\text { Period of particle mixing in test facility prior to } \\
\text { deposition measurements }\end{array}$ & Number & $\mathrm{h}$ \\
\hline Mixer Speed & Mixing fan speed & Number & $\mathrm{rad} / \mathrm{s}$ \\
\hline HVAC Fan Status & Was HVAC fan operating during test? & Text & \\
\hline Furnace Filter Type & $\begin{array}{l}\text { If HVAC fan was operating, what type of filter was } \\
\text { present }\end{array}$ & Text & \\
\hline $\begin{array}{l}\text { Particle Generation } \\
\text { Method }\end{array}$ & Mechanism or device used to generate particles & Text & \\
\hline Particle Composition & Composition of particles & Text & \\
\hline Particle Density & Effective density of particles & Number & $\mathrm{g} / \mathrm{cm}^{3}$ \\
\hline Particles Neutralized? & $\begin{array}{l}\text { Were the generated particles neutralized before } \\
\text { release? }\end{array}$ & Yes/No & \\
\hline Furnishings & General description of furnishings in test facility & Text & \\
\hline Wall Texture & Material covering test facility walls & Text & \\
\hline Ceiling Texture & Material covering test facility ceiling & Text & \\
\hline Floor Type & Material covering test facility floor & Text & \\
\hline Other textures & Additional test facility textures worth noting & Text & \\
\hline Total S.A./Vol Ratio & $\begin{array}{l}\text { Total surface area of test facility to volume of test } \\
\text { facility ratio }\end{array}$ & Number & $\mathrm{m} 2 / \mathrm{m}^{3}$ \\
\hline Notes & $\begin{array}{l}\text { Clarifying or additional information related to test } \\
\text { conditions }\end{array}$ & Text & \\
\hline
\end{tabular}




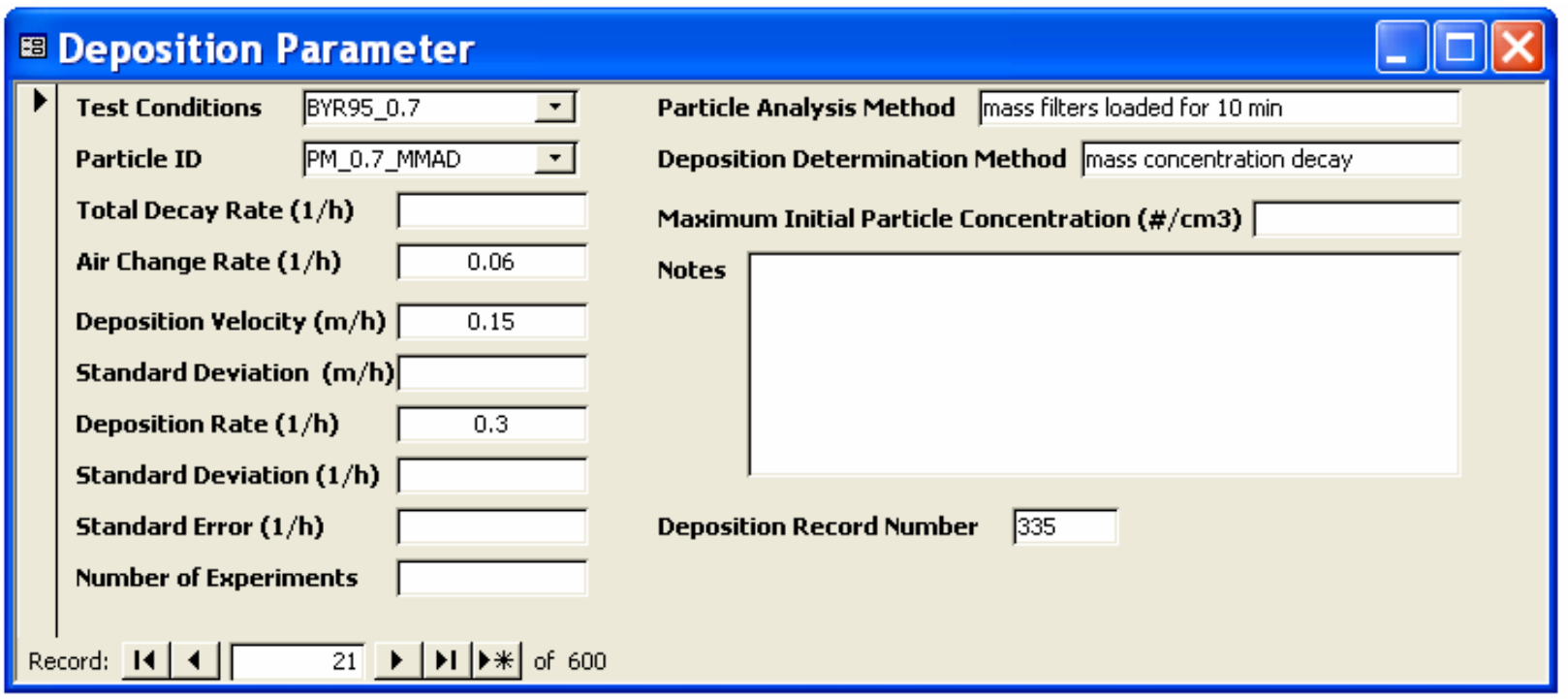

\begin{tabular}{|c|c|c|c|}
\hline Data Field & Field Description & Data Type & Units \\
\hline Test Conditions & Link to Test Condition ID & Number & \\
\hline Particle ID & Link to Particle ID & Number & \\
\hline Total Decay Rate & $\begin{array}{l}\text { Total decay rate of particle including all loss } \\
\text { mechanisms }\end{array}$ & Number & $1 / \mathrm{h}$ \\
\hline Air Change Rate & Air change rate of test facility for specific test & Number & $1 / \mathrm{h}$ \\
\hline Deposition Velocity & Measured deposition velocity of particle & Number & $\mathrm{m} / \mathrm{h}$ \\
\hline Standard Deviation & $\begin{array}{l}\text { Standard deviation of measured deposition } \\
\text { velocity }\end{array}$ & Number & $\mathrm{m} / \mathrm{h}$ \\
\hline Deposition Rate & Measured deposition rate of particle & Number & $1 / \mathrm{h}$ \\
\hline Standard Deviation & Standard deviation of measured deposition rate & Number & $1 / \mathrm{h}$ \\
\hline Standard Error & Standard error of measured deposition rate & Number & $1 / \mathrm{h}$ \\
\hline Number of Experiments & $\begin{array}{l}\text { Number of experiments included in deposition } \\
\text { value }\end{array}$ & Number & \\
\hline Particle Analysis Method & $\begin{array}{l}\text { Method to collect and analyze particle mass or } \\
\text { concentrations for a specific particle diameter }\end{array}$ & Text & \\
\hline $\begin{array}{l}\text { Deposition Determination } \\
\text { Method }\end{array}$ & $\begin{array}{l}\text { Mathematical method used to determine } \\
\text { particle deposition rate }\end{array}$ & Text & \\
\hline $\begin{array}{l}\text { Maximum Initial Particle } \\
\text { Concentration }\end{array}$ & $\begin{array}{l}\text { Maximum particle concentration at start of } \\
\text { deposition experiment to indicate effect of } \\
\text { coagulation }\end{array}$ & Number & $\# / \mathrm{cm}^{3}$ \\
\hline Notes & $\begin{array}{l}\text { Clarifying or additional information regarding } \\
\text { deposition values }\end{array}$ & Text & \\
\hline $\begin{array}{l}\text { Deposition Record } \\
\text { Number }\end{array}$ & $\begin{array}{l}\text { Internal tracking number for quality assurance } \\
\text { checks }\end{array}$ & Autonumber & \\
\hline
\end{tabular}




\section{Partition Coefficient Data Entry Forms}

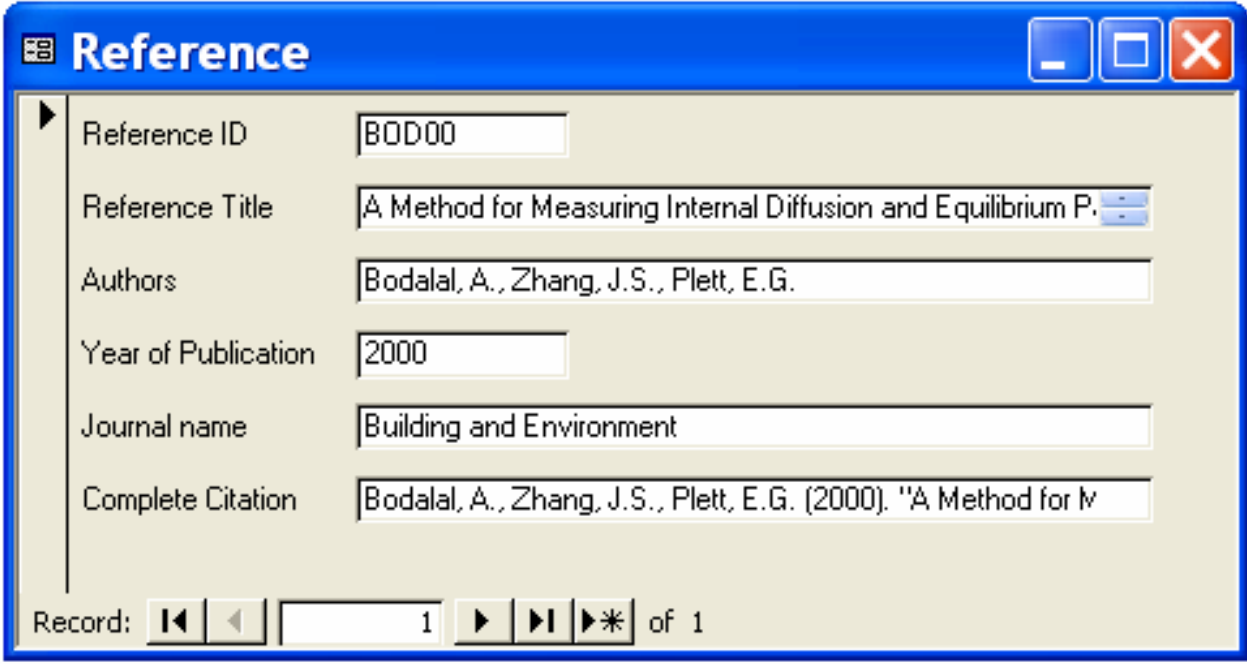

\begin{tabular}{|c|c|c|c|}
\hline Data Field & Field Description & Data Type & Units \\
\hline Reference ID & $\begin{array}{l}\text { Consists of the first three letters of the first author's } \\
\text { last name and abbreviated year of publication }\end{array}$ & Text & \\
\hline Reference Title & Title of reference & Text & \\
\hline Authors & Authors of reference & Text & \\
\hline Year of Publication & Year reference was published & Text & \\
\hline Journal Name & $\begin{array}{l}\text { Title of journal or other document where reference } \\
\text { was published }\end{array}$ & Text & \\
\hline Complete citation & Complete citation for reference & Text & \\
\hline
\end{tabular}

\section{E Material}
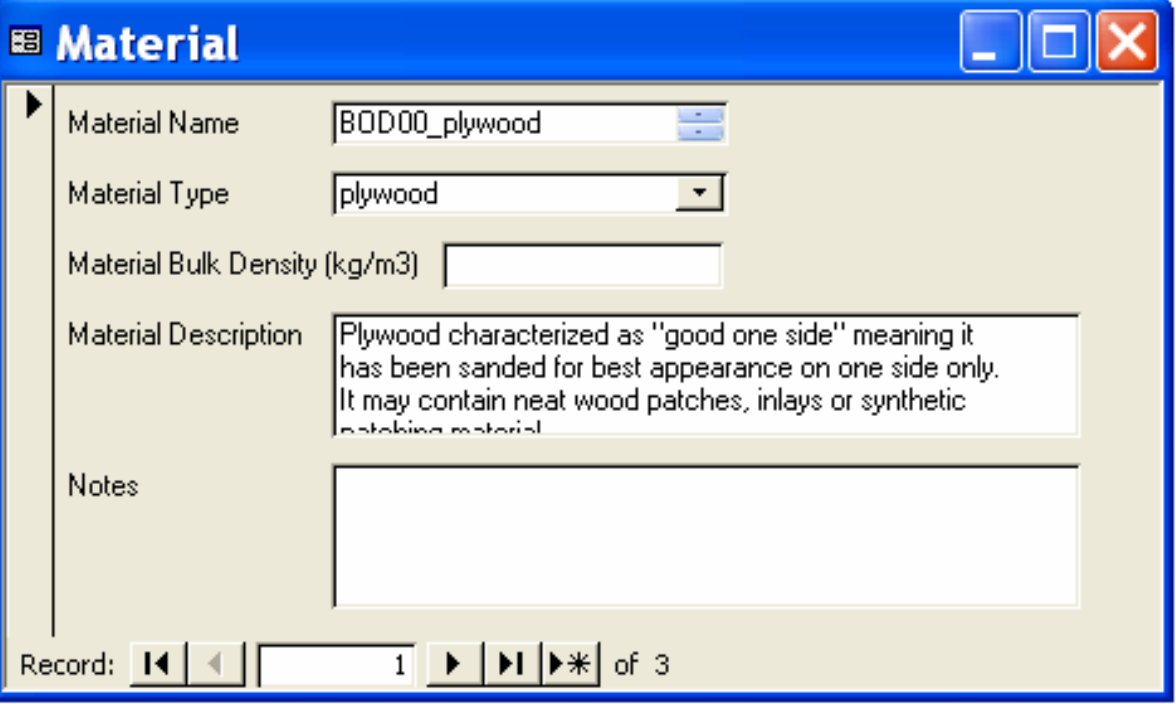

\begin{tabular}{|c|c|c|c|}
\hline Data Field & Field Description & Data Type & Units \\
\hline Material Name & $\begin{array}{l}\text { Consists of Reference ID and internal material } \\
\text { descriptor }\end{array}$ & Text & \\
\hline Material Type & Link to sorbent material type & Number & \\
\hline Material Bulk Density & Bulk density of sorbent material & Number & $\mathrm{kg} / \mathrm{m}^{3}$ \\
\hline Material Description & Description of material used in experiment & Text & \\
\hline Notes & $\begin{array}{l}\text { Clarifying or additional information related to } \\
\text { sorbent material }\end{array}$ & Text & \\
\hline
\end{tabular}




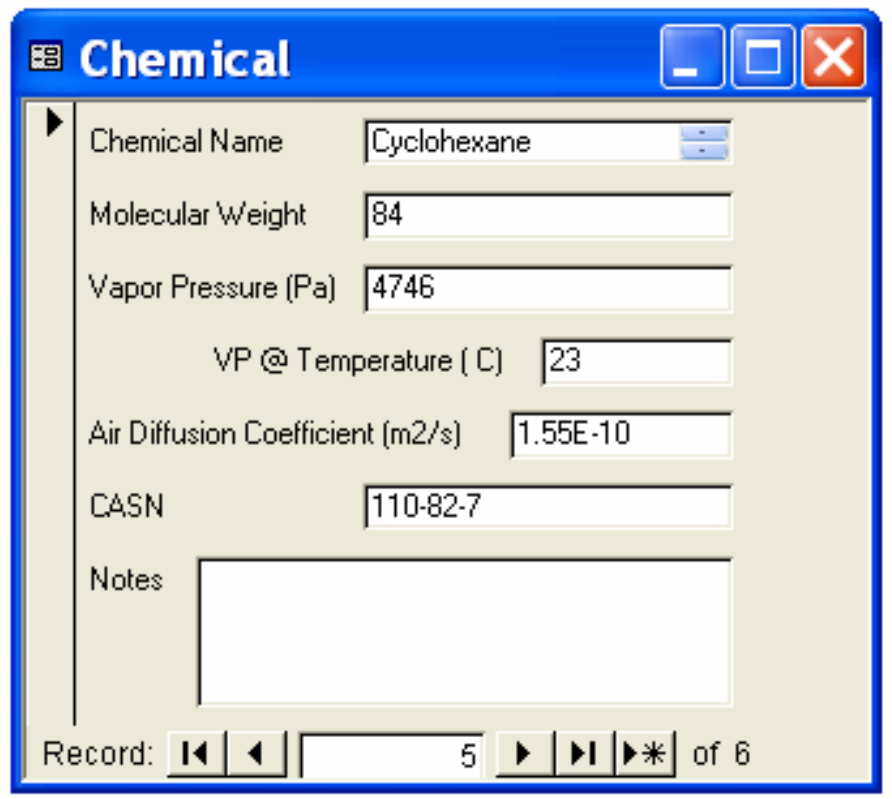

\begin{tabular}{|l|l|c|c|}
\hline Data Field & Field Description & Data Type & Units \\
\hline Chemical Name & Name of chemical used in sorption experiment & Text & Text \\
\hline Molecular Weight & Molecular weight of chemical & Number & $\mathrm{Pa}$ \\
\hline Vapor Pressure & Vapor Pressure of chemical at specific temperature & Number & ${ }^{\circ} \mathrm{C}$ \\
\hline VP@ Temperature & Specific temperature for vapor pressure value & Number & $\mathrm{m}^{2} / \mathrm{s}$ \\
\hline $\begin{array}{l}\text { Air Diffusion } \\
\text { Coefficient }\end{array}$ & Diffusion coefficient of chemical in air & Text & \\
\hline CASN & Chemical Abstract Service Number & Text & \\
\hline Notes & $\begin{array}{l}\text { Clarifying or additional information regarding } \\
\text { chemical used in experiment }\end{array}$ & & \\
\hline
\end{tabular}




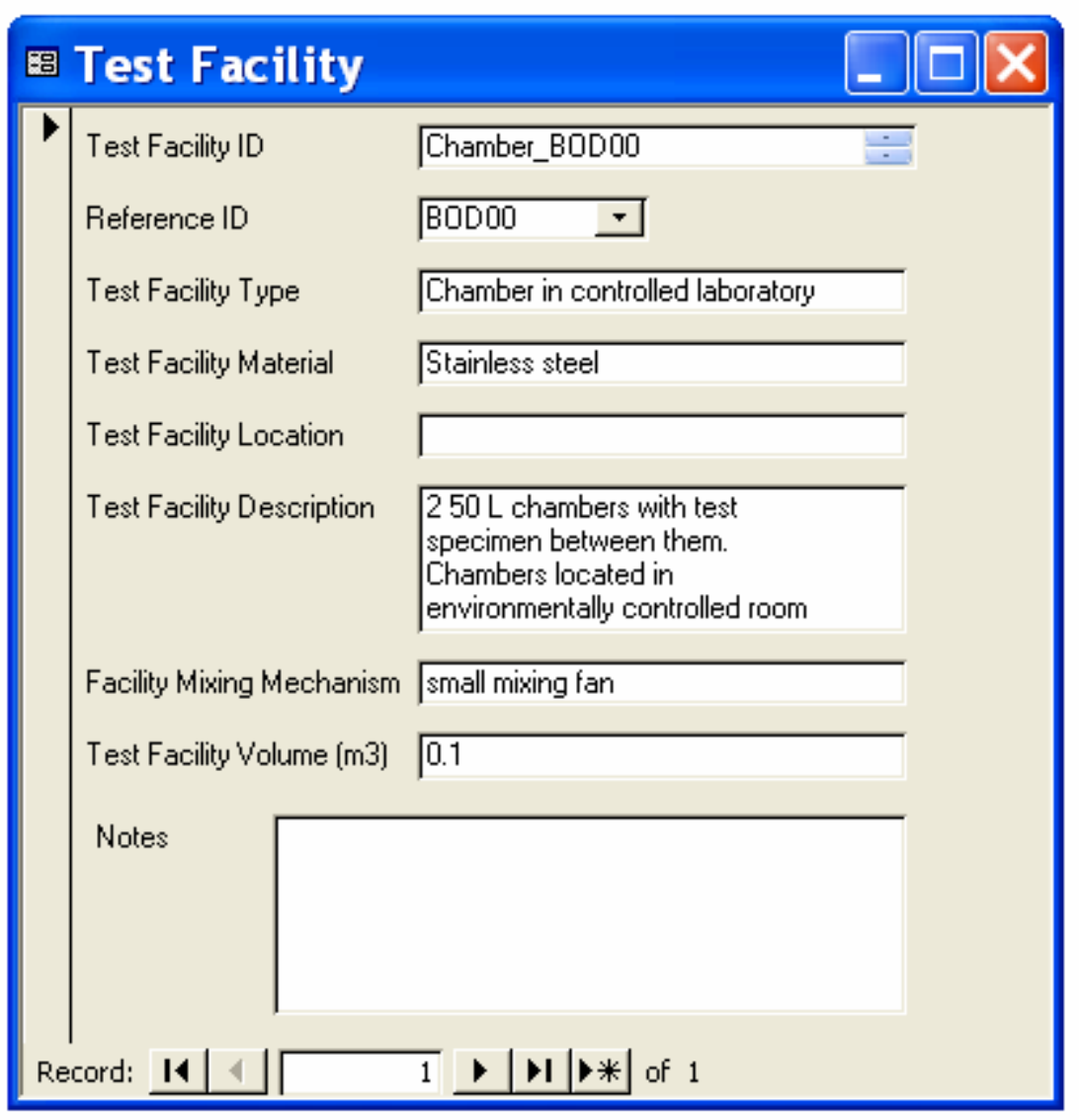

\begin{tabular}{|l|l|c|c|}
\hline Data Field & Field Description & Data Type & Units \\
\hline Test Facility ID & Internal test facility descriptor and Reference ID & Text & \\
\hline Reference ID & Link to Reference ID & Number & \\
\hline Test Facility Type & Type of test facility & Text & \\
\hline Test Facility Material & $\begin{array}{l}\text { Material covering test facility walls, ceiling and } \\
\text { floor }\end{array}$ & Text & Text \\
\hline Test Facility Location & Geographical location of test facility & Text & \\
\hline $\begin{array}{l}\text { Test Facility } \\
\text { Description }\end{array}$ & General description of test facility & Text & \\
\hline $\begin{array}{l}\text { Facility Mixing } \\
\text { Mechanism }\end{array}$ & Mechanism used to mix test facility room air & Number & $\mathrm{m}^{3}$ \\
\hline Test Facility Volume & Volume of test facility air & Text & \\
\hline Notes & $\begin{array}{l}\text { Clarifying or additional information related to test } \\
\text { facility }\end{array}$ & & \\
\hline
\end{tabular}




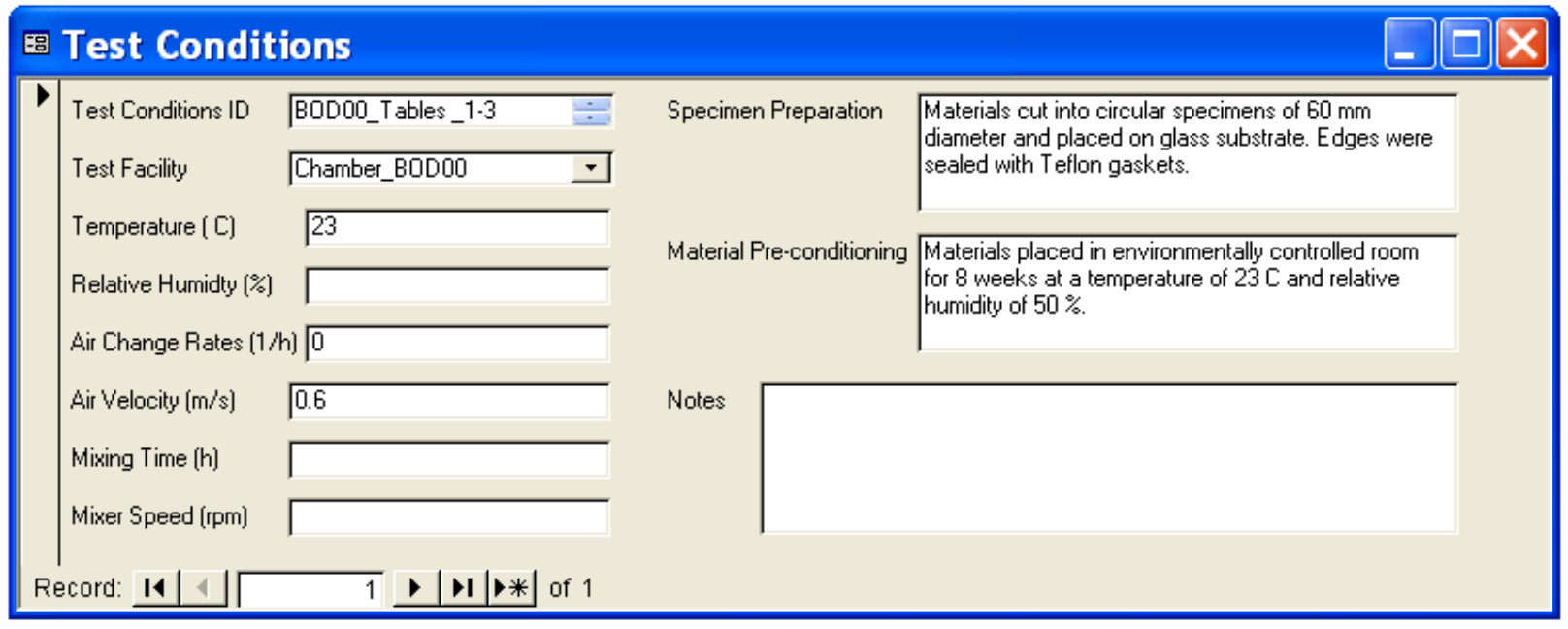

\begin{tabular}{|l|l|c|c|}
\hline Data Field & Field Description & Data Type & Units \\
\hline Test Conditions ID & $\begin{array}{l}\text { Reference ID and internal descriptor of test } \\
\text { conditions }\end{array}$ & Text & \\
\hline Test Facility & Link to Test Facility ID & Number & \\
\hline Temperature & Temperature of test facility air & Number & ${ }^{\circ} \mathrm{C}$ \\
\hline Relative Humidity & Relative humidity of test facility air & $\%$ \\
\hline Air Change Rates & Air change rate of test facility & Number & $1 / \mathrm{h}$ \\
\hline Air Velocity & Velocity of test facility air near surface of material & Number & $\mathrm{m} / \mathrm{s}$ \\
\hline Mixing Time & Mixing time of test facility air & Number & $\mathrm{h}$ \\
\hline Mixer Speed & Rotational speed of test facility mixing mechanism & Number & $\mathrm{rad} / \mathrm{s}$ \\
\hline Specimen Preparation & $\begin{array}{l}\text { General description of preparation of materials for } \\
\text { experiment }\end{array}$ & Text & \\
\hline $\begin{array}{l}\text { Material Pre- } \\
\text { conditioning }\end{array}$ & $\begin{array}{l}\text { Any pre-experimental procedures for the material } \\
\text { specimen }\end{array}$ & Text & \\
\hline Notes & $\begin{array}{l}\text { Clarifying or additional information regarding test } \\
\text { conditions }\end{array}$ & Text & \\
\hline
\end{tabular}




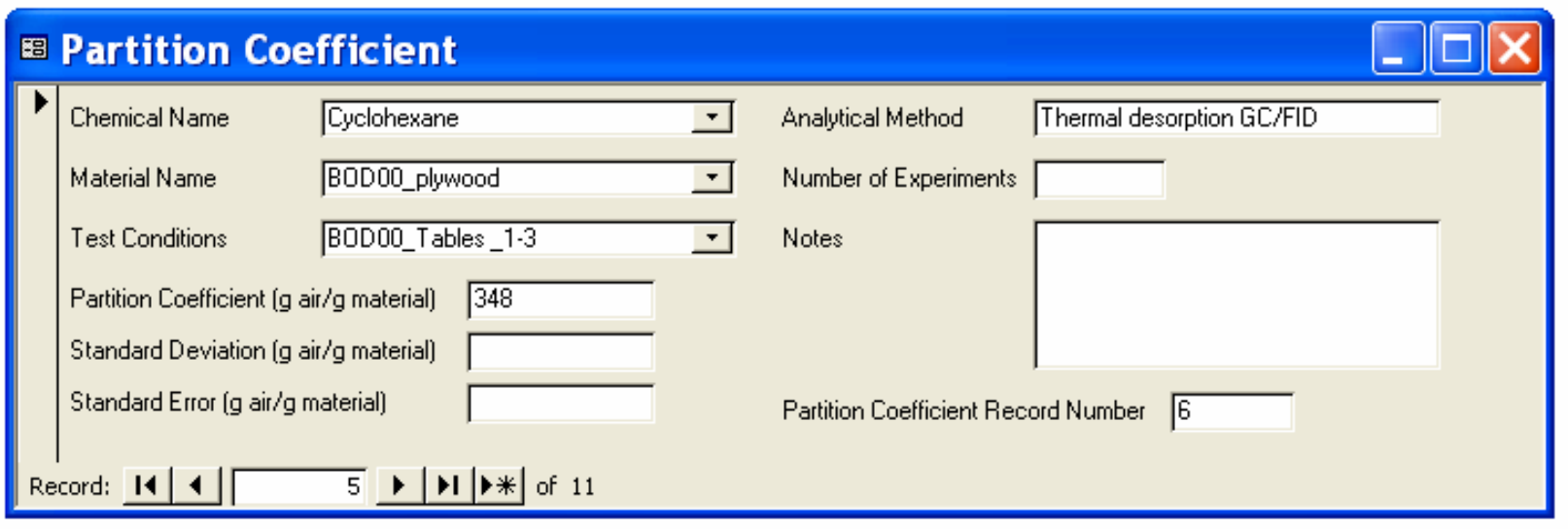

\begin{tabular}{|c|c|c|c|}
\hline Data Field & Field Description & Data Type & Units \\
\hline Chemical Name & Link to Chemical ID & Number & \\
\hline Material Name & Link to Material ID & Number & \\
\hline Test Conditions & Link to Test Conditions ID & Number & \\
\hline Partition Coefficient & $\begin{array}{l}\text { Measure partition coefficient for given } \\
\text { chemical and material }\end{array}$ & Number & $\begin{array}{c}\text { g air/ } \\
\text { g material }\end{array}$ \\
\hline Standard Deviation & $\begin{array}{l}\text { Standard deviation of partition coefficient } \\
\text { measurement }\end{array}$ & Number & $\begin{array}{c}\text { g air/ } \\
\text { g material }\end{array}$ \\
\hline Standard Error & $\begin{array}{l}\text { Standard error of partition coefficient } \\
\text { measurement }\end{array}$ & Number & $\begin{array}{c}\text { g air/ } \\
\text { g material }\end{array}$ \\
\hline Analytical Method & $\begin{array}{l}\text { Method used to measure chemical } \\
\text { concentration }\end{array}$ & Text & \\
\hline $\begin{array}{l}\text { Number of } \\
\text { Experiments }\end{array}$ & $\begin{array}{l}\text { Number of experiments included in partition } \\
\text { coefficient value }\end{array}$ & Number & \\
\hline Notes & $\begin{array}{l}\text { Clarifying or additional information regarding } \\
\text { partition coefficient value }\end{array}$ & Text & \\
\hline $\begin{array}{l}\text { Partition Coefficient } \\
\text { Record Number }\end{array}$ & $\begin{array}{l}\text { Internal tracking number for quality assurance } \\
\text { checks }\end{array}$ & Text & \\
\hline
\end{tabular}




\section{APPENDIX B: ContamLink 2.4 User Manual}

\section{Introduction}

ContamLink is a tool that is used to facilitate the transfer of information from contaminant emission databases to CONTAM as CONTAM source/sink elements. These databases contain experimental contaminant modeling data, including source emission rates for volatile organic compounds, inorganic gases and particles, particle deposition rates, sorption rates, and air cleaning removal.

\section{Getting ContamLink}

ContamLink can be downloaded from CONTAM's homepage

(http://bfrl.nist.gov/IAQanalysis/software/index.htm). Installation instructions can be found on ContamLink's download page.

\section{Using ContamLink}

The ContamLink main window has three parts: the menubar, the sidebar and the data viewer (see Figure 1).

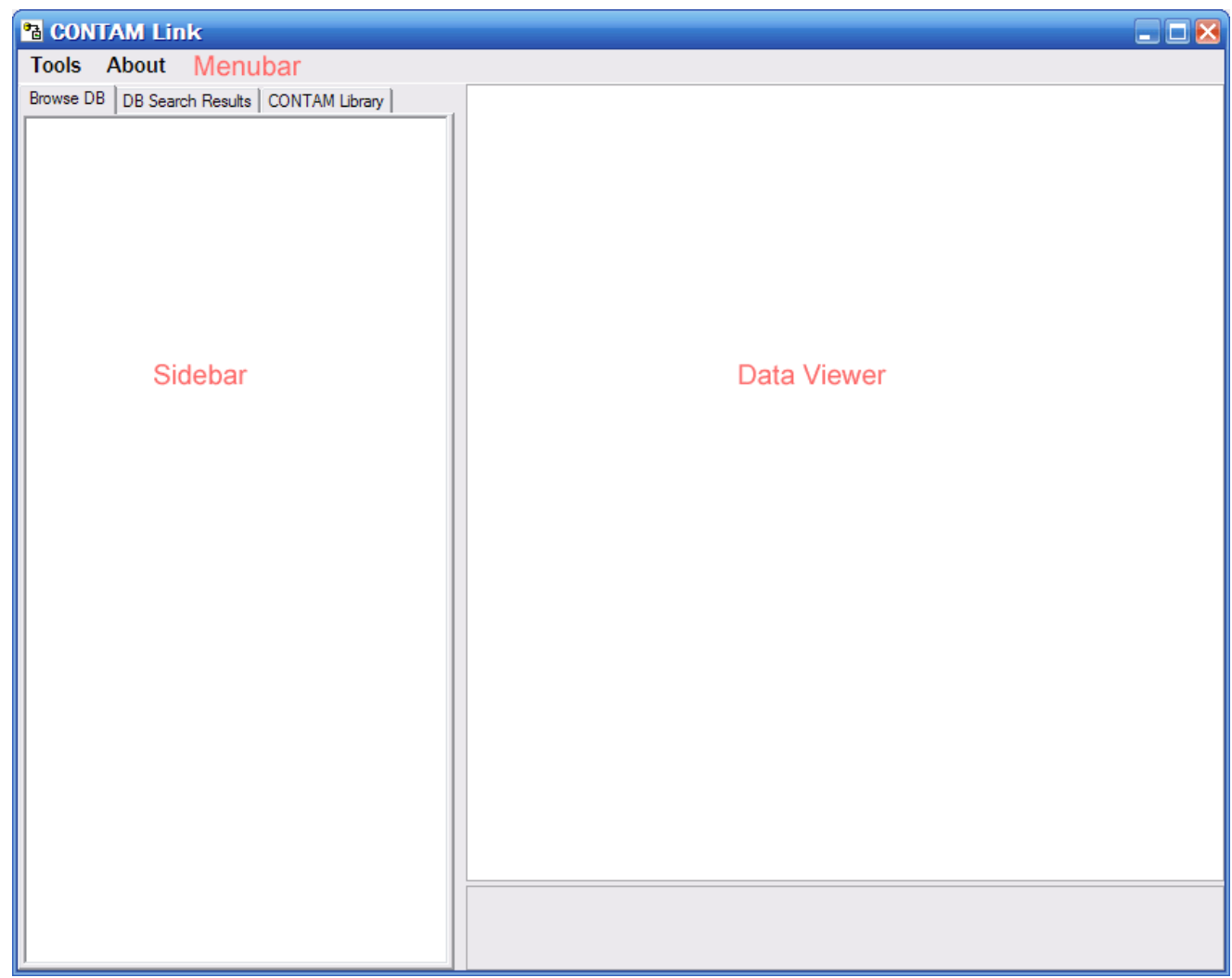

Figure 1. ContamLink main window.

\section{Menubar}

The Tools dropdown menu on the window bar includes the commands to open or search a database, create a source/sink or super source/sink, or exit the program. 


\section{Sidebar}

The sidebar has three functions. The first is to browse a database's contents. This is done with a tree to show the hierarchy of the database. The second function of the sidebar is to show results of searching the database. The third function is the library manager. This library manager is similar to the one found in ContamW (Walton and Dols, 2005). Species and source/sinks that are created in ContamLink can be managed here.

\section{Data Viewer}

The data viewer displays information from the database. The data shown depends on what is selected when browsing or searching the database. The data viewer is not used with the library manager.

\section{Loading a database}

A database can be loaded using Tools $\Rightarrow$ Open Database from the menu or using the $\mathrm{Ctrl}+\mathrm{O}$ keyboard shortcut. The dialog shown in Figure 2 is then presented.

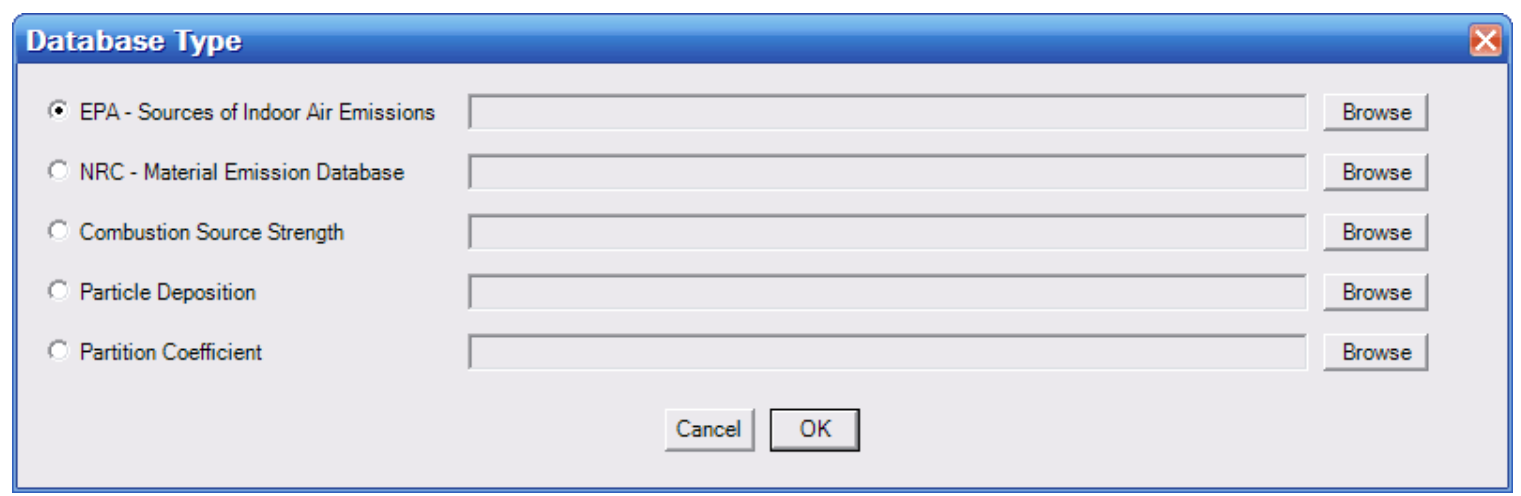

Figure 2. Choosing a database window.

Pick the type of database file to use on the left. Then use the corresponding browse button to pick the database file to use. Databases are available on the CONTAM homepage (http://bfrl.nist.gov/IAQanalysis/software/CONTAMLINKdatabases.htm) and the database filenames match the respective "database type". For example, the Particle Deposition filename is "Particle Deposition." After the database is successfully loaded, a dialog box will appear. Click OK to begin using the database.

\section{Browsing a database}

After a database is loaded the contents of the database can be browsed. The browse tab, on the sidebar, is used to show the hierarchy of the database. Most items in the hierarchy show information in the data viewer, which correspond to a record in a table or multiple tables that are joined together from the database. Each database has a slightly different hierarchy which is presented below:

\section{EPA Database}

The first level of the EPA VOC source database shows the categories of materials contained in the database. The next level provides the types of materials in this category (e.g., water-based 
paint is a type of Paint and Coating). Below each material type are specific studies that generated emission results. Clicking on a study name shows a more detailed description of the material used in the study. The different test conditions used for a specific study are listed in the next level, with details in the data viewer window. Finally, all of the chemical compounds measured are listed. Clicking on each compound shows emission rate results and model information in the data viewer. Figure 3 shows the EPA VOC source database hierarchy with the test conditions highlighted for the data viewer window.

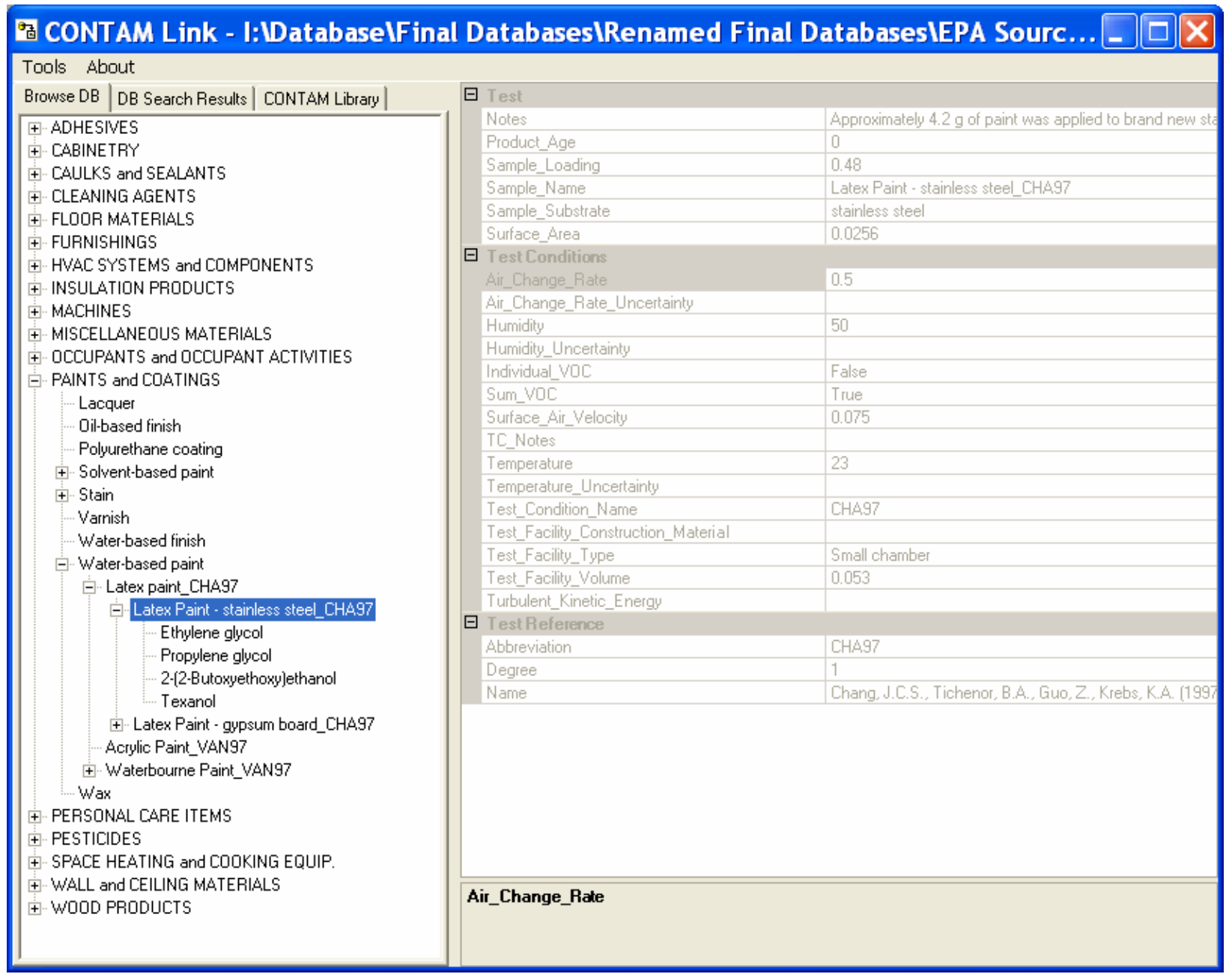

Figure 3. Browsing capabilities of VOC source emissions database with ContamLink and material test conditions results display.

\section{NRC Database}

The NRC VOC Source emission database has a similar hierarchy to the EPA VOC source database (see Figure 4). 


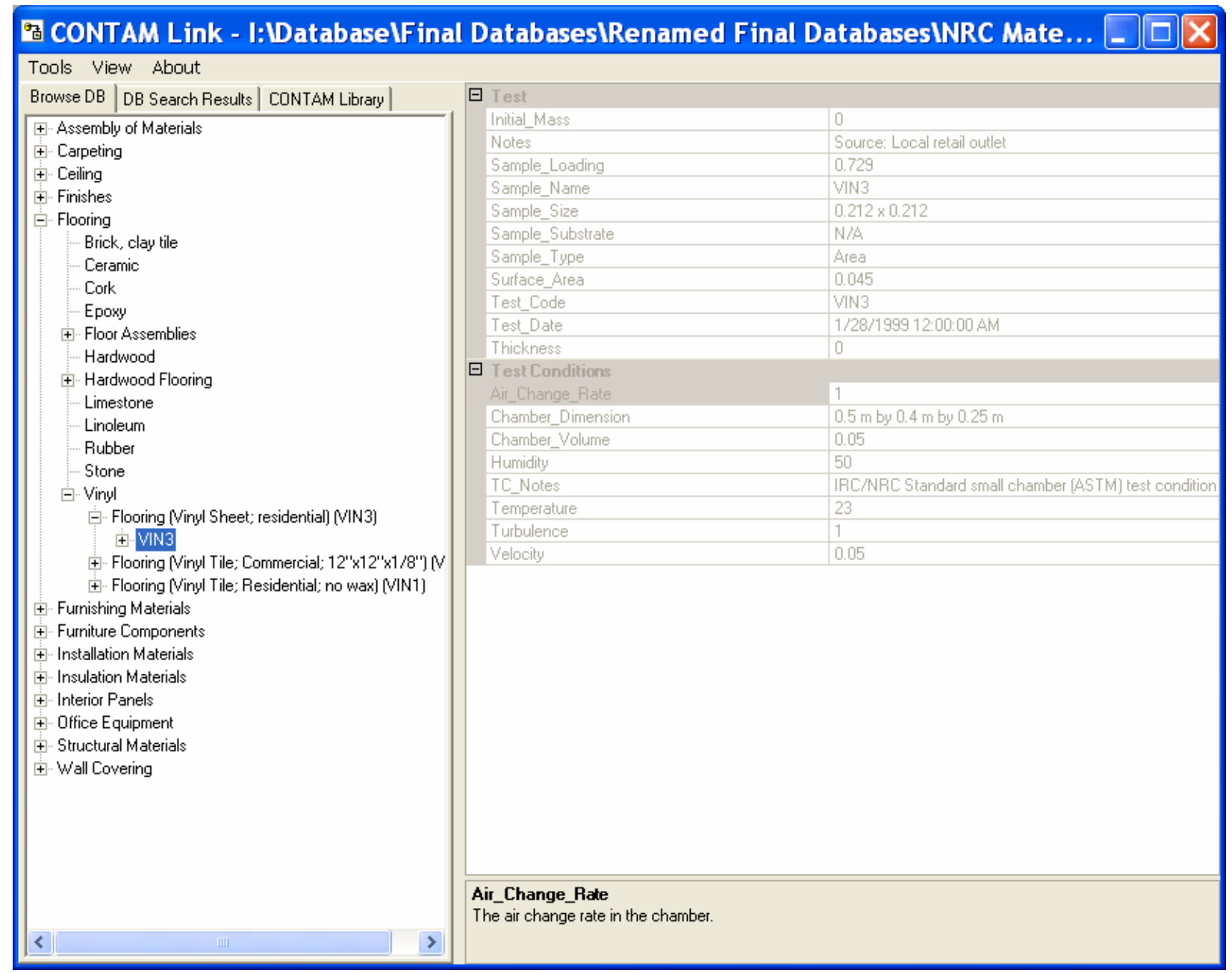

Figure 4. Browsing capabilities of NRC VOC source emissions database with ContamLink and environmental test conditions results display.

\section{Combustion Source Strength Database}

The first level of the combustion source strength database hierarchy is category of combustion appliance (see Figure 5). The next level includes the different types of appliances in each category (e.g., kerosene space heater is type of space heater). Under each appliance type is a list of specific studies, which, when highlighted, show the appliance and test facility specifications in the data viewer. The next level lists different test conditions for each study with the specific values given in the data viewer. The final level lists all contaminants measured in each study with contaminant properties, emission factors, and model information in the data viewer. 


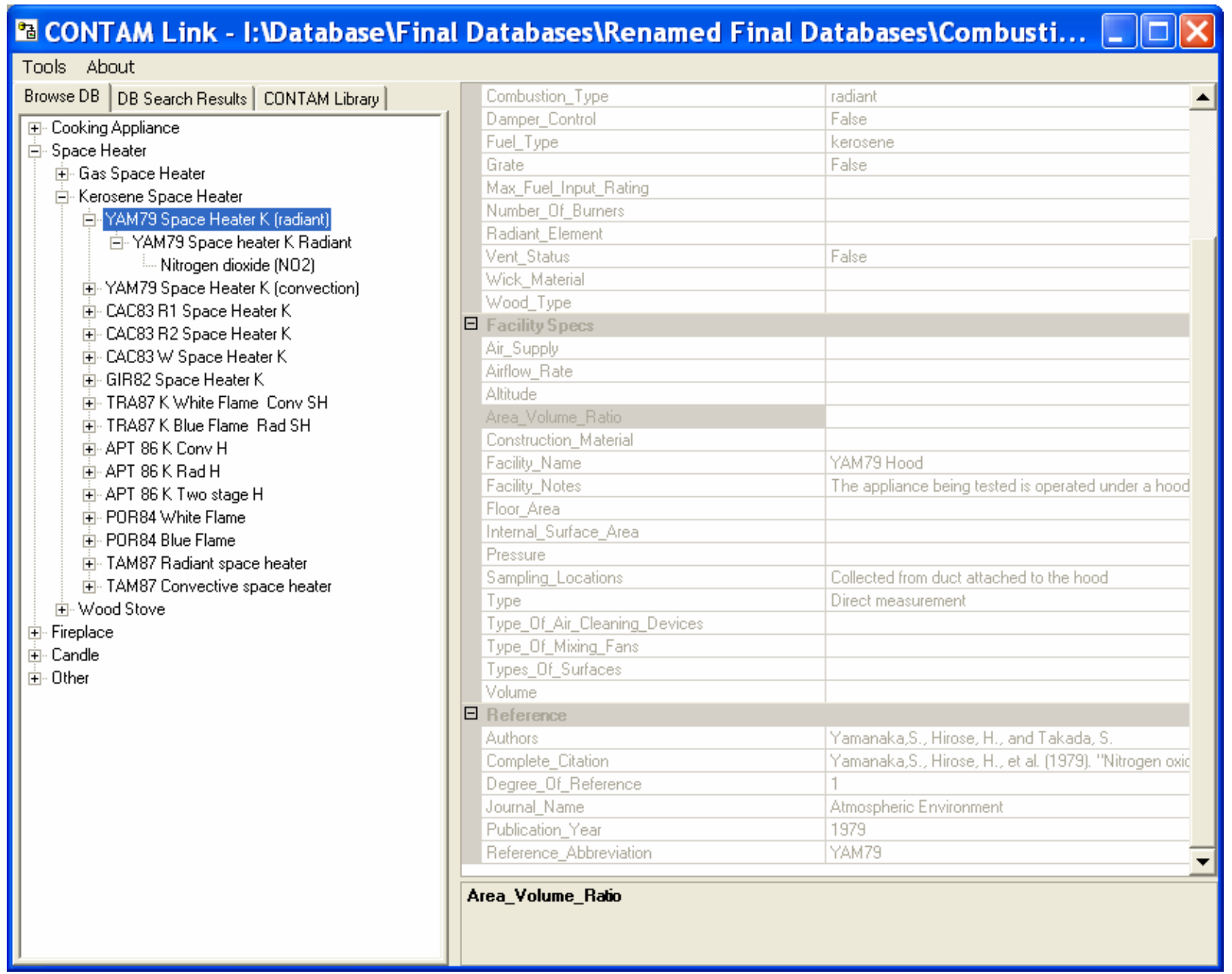

Figure 5. Browsing capabilities of Combustion Source Strength database with ContamLink and appliance and test facility specification in results display.

\section{Particle Deposition Database}

The particle deposition database is first organized according to the type of test facility used for each deposition study (see Figure 6). The next level lists each deposition study for that type of facility with reference and test facility details in the data viewer. The different test conditions for each study is provided in the next level with specific values given in the data viewer. Finally, specific particle sizes are listed with the associated deposition rates given in the data viewer. 


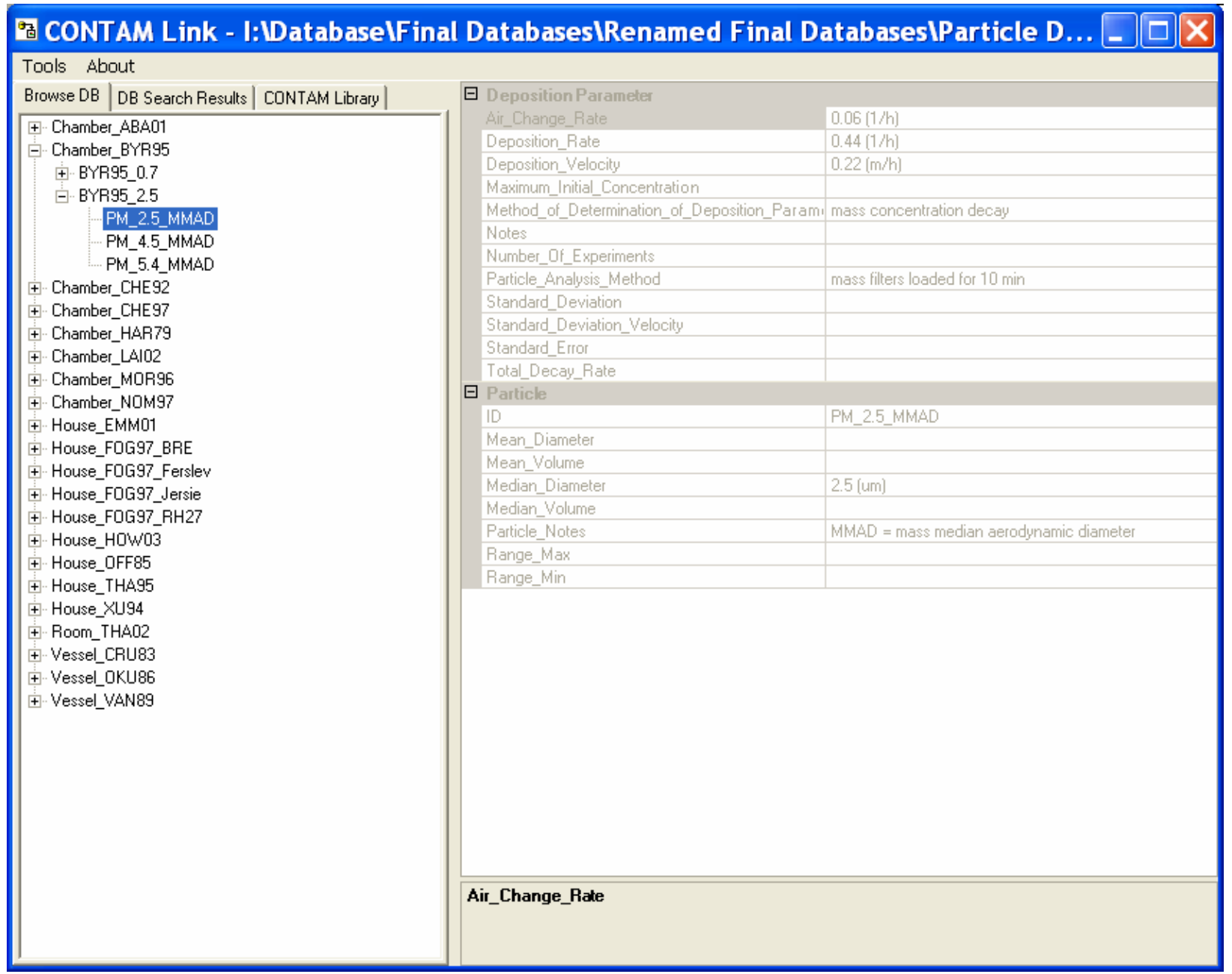

Figure 6. Browsing capabilities of Particle Deposition database with ContamLink and particle deposition results in results display.

\section{Partition Coefficient Database}

The first level of the Partition Coefficient database hierarchy is a list of sorptive indoor materials (see Figure 7). Under each material type is a list of sorption studies which displays more information about the material in the data viewer. The next level lists the chemicals used in the sorption study with information about the tests in the data viewer. 


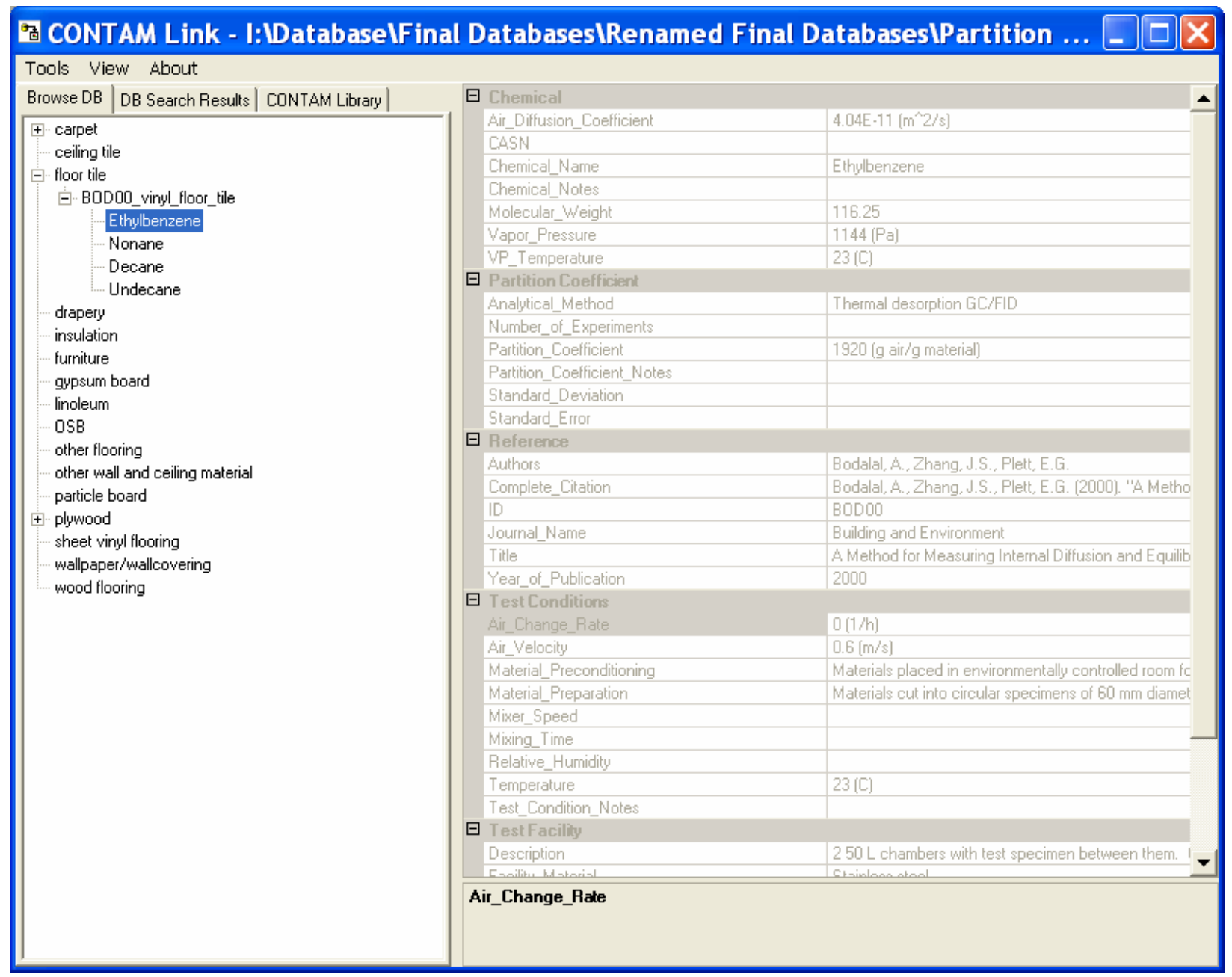

Figure 7. Browsing capabilities of Partition Coefficient database with ContamLink and partition coefficient results in results display.

\section{Searching a database}

Searching the database makes it easier to find records in the database. Search the database by using Tools $\Rightarrow$ Search Database from the menu or using the $\mathrm{Ctrl}+\mathrm{S}$ keyboard shortcut. The dialog shown in Figure 8 is then presented.

The first step is to define the search parameters. The search parameters available vary depending on the database that is used. Table 1 lists all of the available search parameters for each database. On the dialog select a parameter, an operator and enter a value for the parameter. Then add that parameter set to the query by pressing the Add button. When using more than one parameter you also need to select if the parameters are to be used together using the AND operator. Or if the parameters are to be used separately using the OR operator. 


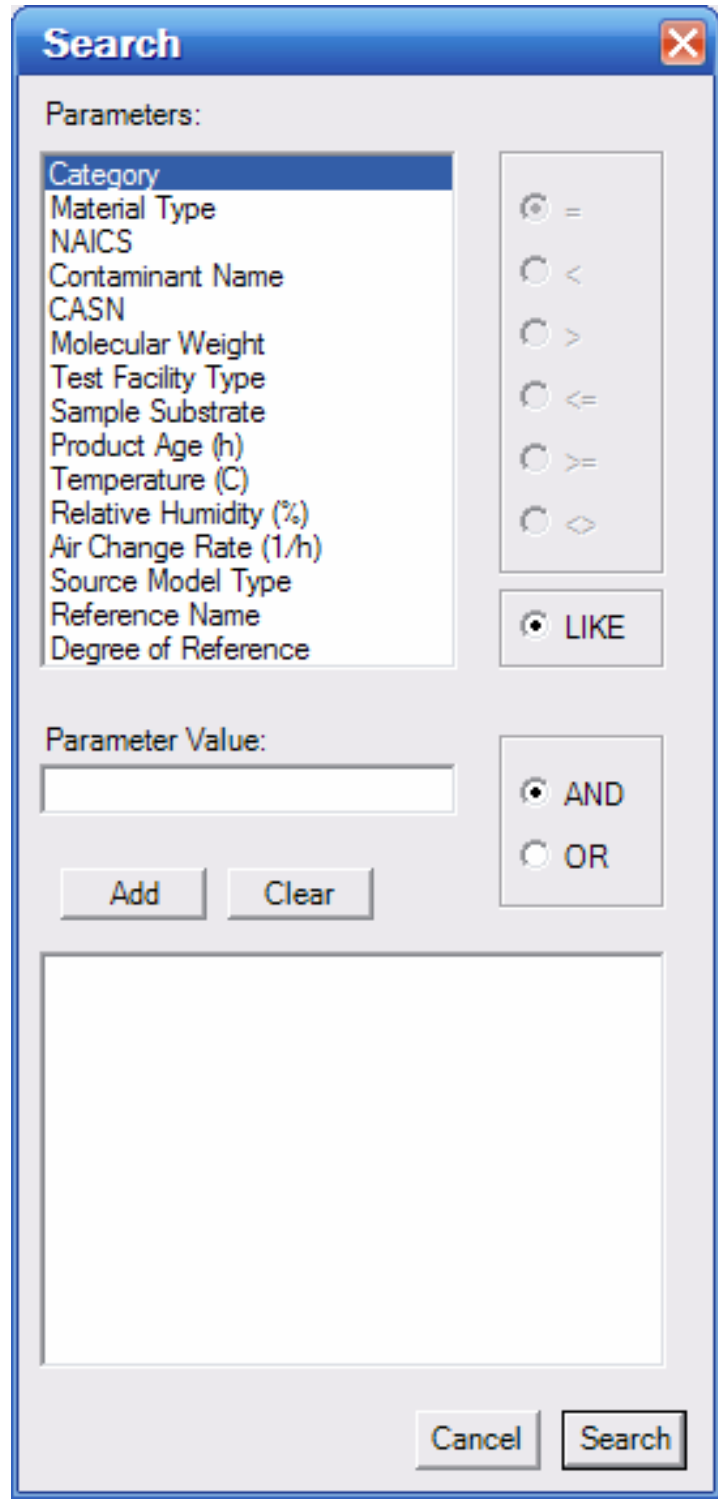

Figure 8. Searching capabilities for VOC emissions database.

Initiate the search by pressing the Search button. A message bow will give the number of records that matched the search parameters. The records can be found in the Search tab of the sidebar. The search tab shows the same hierarchy as the browse tab but only includes the records that matched the search query. The search results can also be browsed like the browse tab. 
Table 1. Search Parameters for each Model Input Database

\begin{tabular}{|l|l|l|l|}
\hline VOC Emission Rates & $\begin{array}{c}\text { Combustion } \\
\text { Emission Rates }\end{array}$ & \multicolumn{1}{|c|}{$\begin{array}{c}\text { Particle Deposition } \\
\text { Rates }\end{array}$} & \multicolumn{1}{|c|}{$\begin{array}{c}\text { Partition } \\
\text { Coefficients }\end{array}$} \\
\hline Category & Category & Test Facility Type & Material Type \\
Material Type & Combustion Type & Area/Volume Ratio & Contaminant Name \\
NAICS & Fuel Type & $(1 / \mathrm{m})$ & Molecular Weight \\
Contaminant Name & Contaminant Name & Air Change Rate $(1 / \mathrm{h})$ & Vapor Pressure $($ Pa) \\
CASN & Contaminant Class & Mixing Mechanism & CASN \\
Molecular Weight & Molecular Weight & Particle ID & Test Facility Type \\
Test Facility Type & Test Facility Type & Mean Diameter $(\mu \mathrm{m})$ & Temperature $\left({ }^{\circ} \mathrm{C}\right)$ \\
Sample Substrate & Facility Altitude & Median Diameter $(\mu \mathrm{m})$ & R.H. $(\%)$ \\
Product Age $(\mathrm{h})$ & Fuel Consumption & Particle Analytical & Air Change Rate $(1 / \mathrm{h})$ \\
Temperature $\left({ }^{\circ} \mathrm{C}\right)$ & Rate $(\mathrm{kJ} / \mathrm{h})$ & Method & Reference Authors \\
R.H. $(\%)$ & Equation Name & Generation Method & Year of Publication \\
Air Change Rate $(1 / \mathrm{h})$ & Reference Authors & Particle Composition & Degree of Reference \\
Source Model Type & Year of Publication & Neutralized Particles? & \\
Reference Authors & Degree of Reference & Reference Authors & \\
Year of Publication & \multicolumn{2}{|l}{} \\
Degree of Reference & \multicolumn{2}{|l}{ Year of Publication } & \\
\hline
\end{tabular}

\section{Library Manager}

The third function of the side bar is the library manager. CONTAM libraries are external files whose purpose is to store pre-defined/user-defined simulation elements (schedules, wind pressure profiles, airflow elements, and duct elements) for use in multiple CONTAM simulations. The library manager is a way to easily create and manage these library files. ContamLink allows the user to only manage species and sources, since these are the only elements that are needed by ContamLink. Other elements like filters that can use the species in these libraries need to be defined in ContamW. Those elements will remain in the library when it is saved.

\section{Library File}

The user may either open an existing species-related library file or create a new one through ContamLink. To open an existing file press the "Browse" button and select the appropriate library file. The name of the library file opened and any description provided in the file will be displayed in the respective name and description fields. To manually create a new library file press the "New" button (see "Creating CONTAM Sources/sinks from a Database" to automatically add species and sources to library file). This will provide a clear field in the Library Elements part of the dialogue box. After adding new elements to the Element name list the list may be saved as a new CONTAM Library file. 


\section{Species and Source/Sinks}

This is a list of species and source/sink elements present in the current library file. A more detailed description of the element will be displayed below the Element name list, if a description for the element is available.

There are a few options to add and remove elements from the list. A new element may be created by pressing the new button then following the appropriate steps to create a new element.

Elements already in the library file may be modified by first selecting them from the list and pressing the edit button. If a species is not used by a source/sink in the library file it may be removed by selecting it from the element list and then pressing the delete button. Source/Sinks can always be deleted from a library.

\section{Creating CONTAM sources/sinks from a database}

CONTAM source/sinks are created using a wizard to define species and source/sink elements. By either searching or browsing a database, records from the database are chosen to be the basis for a CONTAM source/sink element. The lowest items in the browse tree or search tree (either contaminant names or particle sizes) correspond to a CONTAM source/sink element. Right click on one of these items and select Create Source/Sink from the context menu (see Figure 9). A wizard is started to create a source/sink. The wizard can also be started using Tools $\Rightarrow$ Create Source/Sink from the menu or using the $\mathrm{Ctrl}+\mathrm{C}$ keyboard shortcut.

\section{O目 CONIAM LInk -}

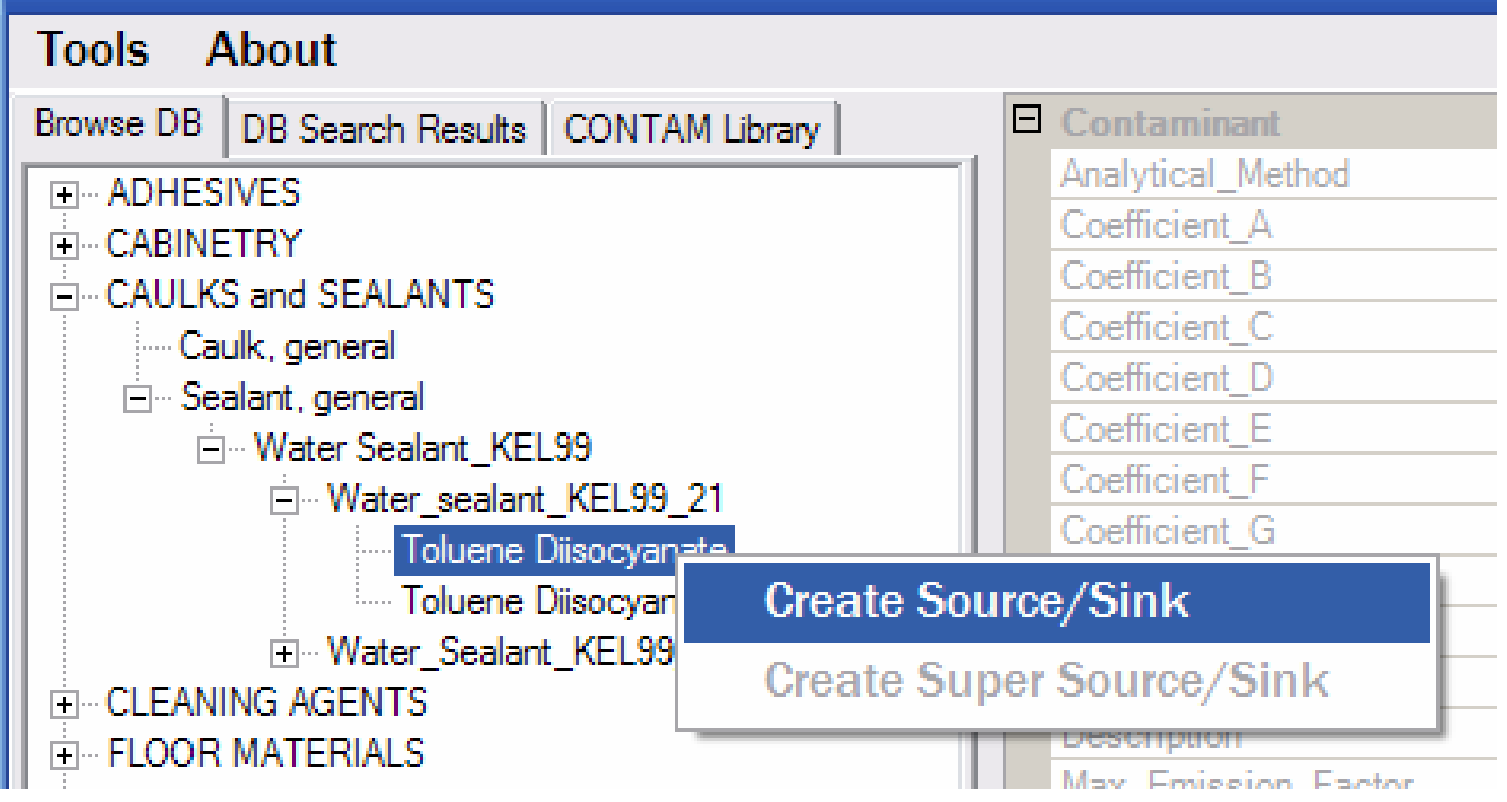

Figure 9. Automatically adding a source/sink to library manager using ContamLink wizard.

\section{Pick a species}

If a species exists in the current library then you will be given the opportunity to reuse a species for the source being created. Otherwise the wizard will start with the next step. You can select to 
create a new species or use an existing species. Information about the species selected from the database is shown on the left side of the window (see Figure 10).

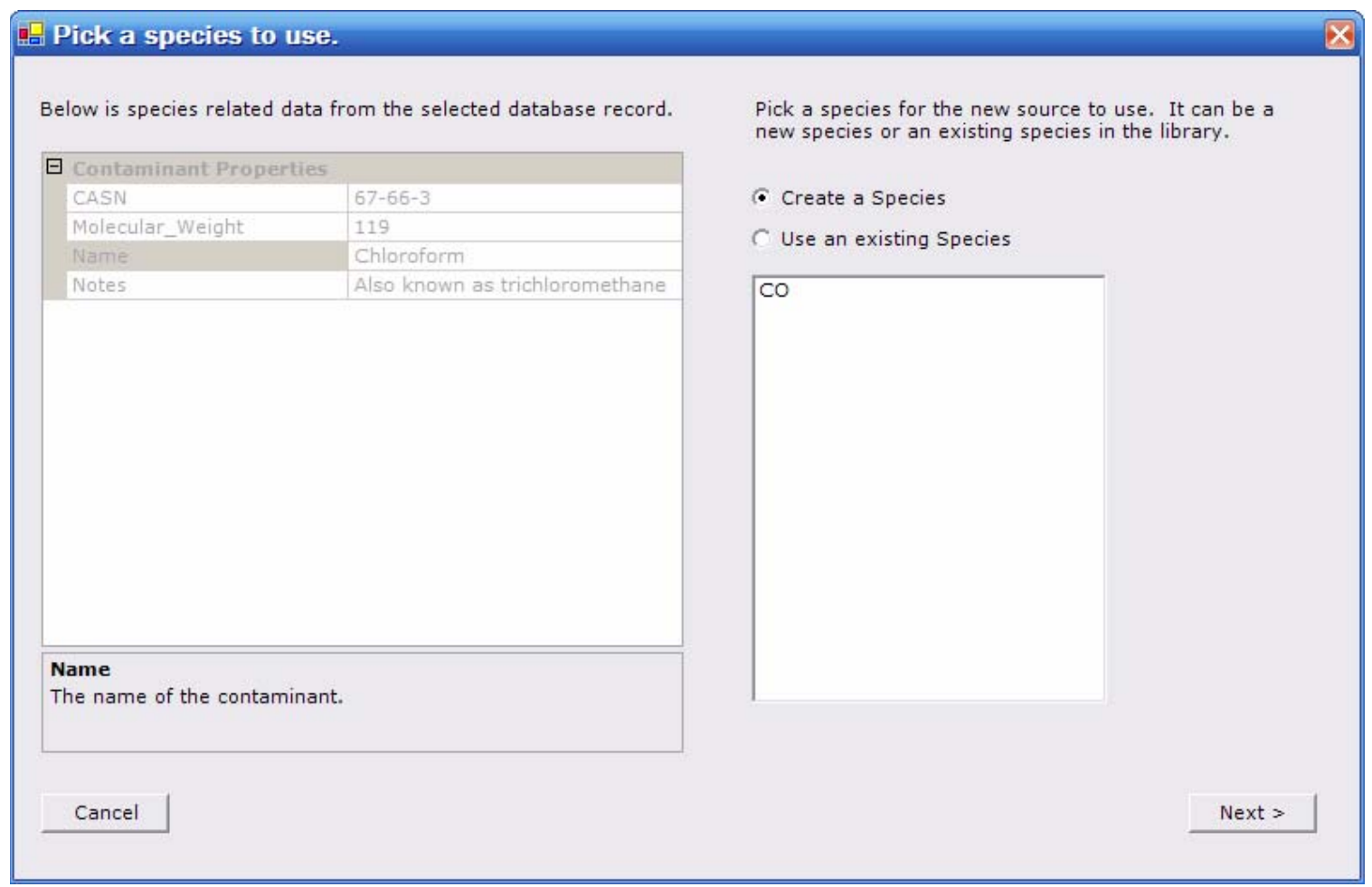

Figure 10. Selecting a species for library file.

\section{Define a Species}

If there is no existing species or an existing species was not used then you have to define a species for the source/sink to use (see Figure 11). The species being defined can be edited on the right side of the window. Information about the selected species from the database is shown on the left side of the window. The name of the species from the database is reused. Because there is a limit on the length of a species name the name may be trimmed. Also, there cannot be any spaces in the species name. The full name is put into the description. If available the molecular weight is also taken from the database. 


\begin{tabular}{|c|c|c|c|}
\hline \multicolumn{2}{|c|}{$\begin{array}{l}\text { Species related data from the selected database record is below } \\
\text { to assist in defining the species. }\end{array}$} & \multicolumn{2}{|c|}{$\begin{array}{l}\text { Define the species for the source/sink below. Some fields have } \\
\text { been populated with data from the selected database record. }\end{array}$} \\
\hline \multicolumn{2}{|c|}{$\boxminus$ Contaminant Properties } & \multicolumn{2}{|l|}{$\boxminus$ Basic Properties } \\
\hline CASN & $67-66-3$ & Description & Chloroform Also known as trichlor \\
\hline Molecular_Weight & 119 & Name & Chloroform \\
\hline Name & Chloroform & \multicolumn{2}{|l|}{ 曰 Species Properties } \\
\hline \multirow[t]{9}{*}{ Notes } & Also known as trichloromethane & Decay Rate (1/s) & 0 \\
\hline & & ⿴囗十 Default Concentration & $0(\mathrm{~kg} / \mathrm{kg})$ \\
\hline & & 田 Diffusion Coefficient & $1.99999994947575 \mathrm{E}-05\left(\mathrm{~m}^{2} / \mathrm{s}\right)$ \\
\hline & & ⿴囗十 Effective Density & $0\left(\mathrm{~kg} / \mathrm{m}^{3}\right)$ \\
\hline & & 田 Mean Diameter & $0(\mathrm{~m})$ \\
\hline & & Molecular Weight $(\mathrm{kg} / \mathrm{mol})$ & 119 \\
\hline & & Simulated & False \\
\hline & & ⿴囗十 Specific Heat & $1000(\mathrm{~J} / \mathrm{kgK})$ \\
\hline & & Trace & True \\
\hline \multicolumn{2}{|c|}{$\begin{array}{l}\text { Name } \\
\text { The name of the contaminant. }\end{array}$} & \multicolumn{2}{|l|}{$\begin{array}{l}\text { Name } \\
\text { The name of the element }\end{array}$} \\
\hline \multicolumn{2}{|l|}{ Cancel } & & Next > \\
\hline
\end{tabular}

Figure 11. Defining a species using ContamLink wizard. 


\section{Picking a Source/Sink Model}

Next a source/sink model must be chosen. Some model selections may be limited depending on the database being used due to what is expected to be in those databases. Information about the model from the database is shown on the left hand side of the wizard (see Figure 12).

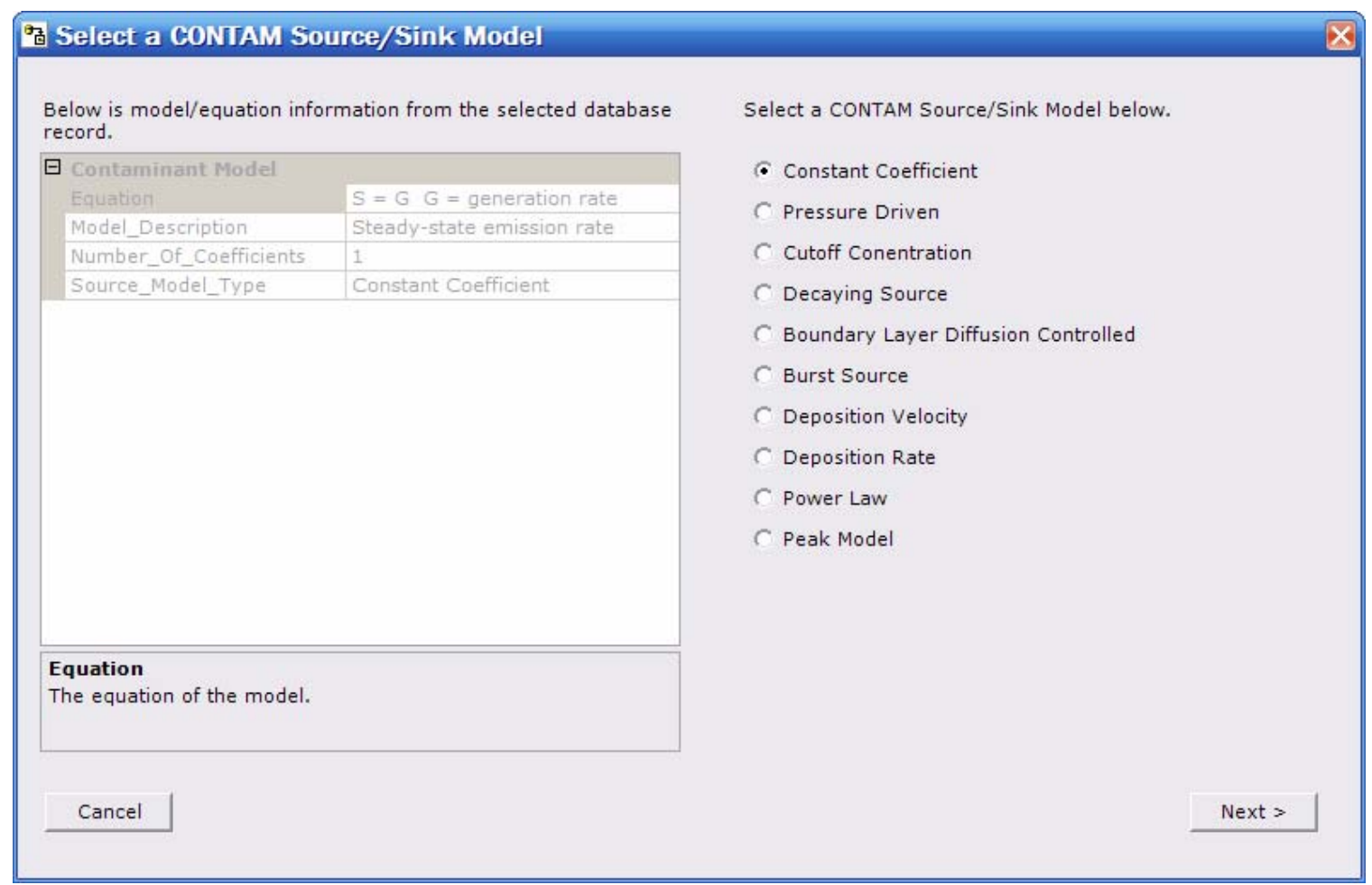

Figure 12. Selecting a CONTAM source/sink model using ContamLink wizard. 


\section{Defining the Source/Sink}

When defining the source/sink some fields will be initialized with values from the database record. Some of the information from the database records is shown on the left side of the window (see Figure 13). After defining the source, the wizard is complete and the new species and source/sink will be shown in the library manager.

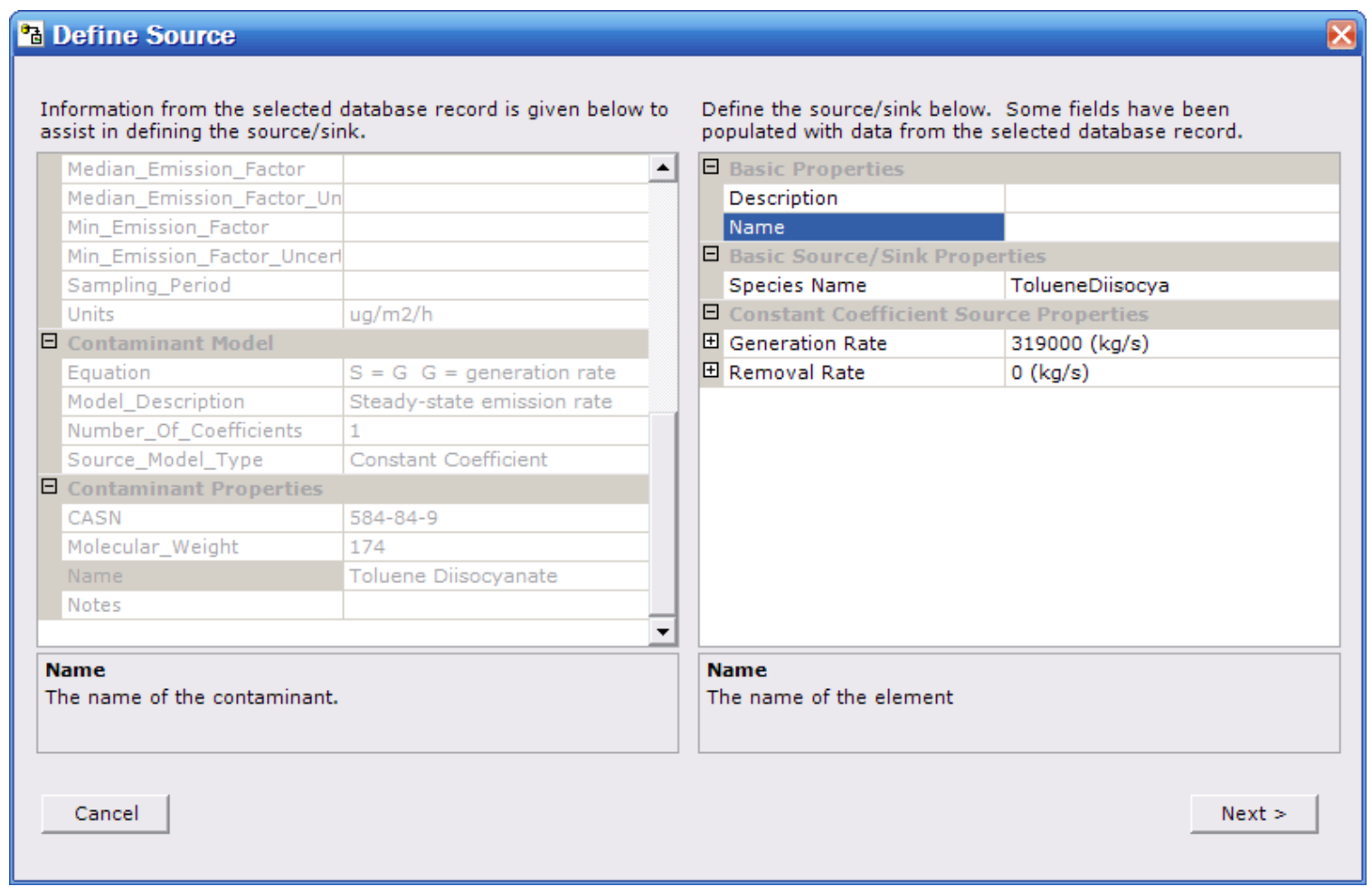

Figure 13. Defining a source/sink using ContamLink wizard.

\section{Creating a Super Source/Sink from a database}

The super element allows multiple elements of the other types to be combined into a single element. This can reduce repetitious work required to create multiple sources throughout a building by allowing multiple sources to be represented by a single icon on the SketchPad. Creating a super source/sink is similar to creating a simple source/sink, however the process is started at a different level in the Browse or Search tree (see Figure 14). To create a super source/sink you select the level that corresponds to study test conditions, which is one level above the selection point for a simple source/sink. 


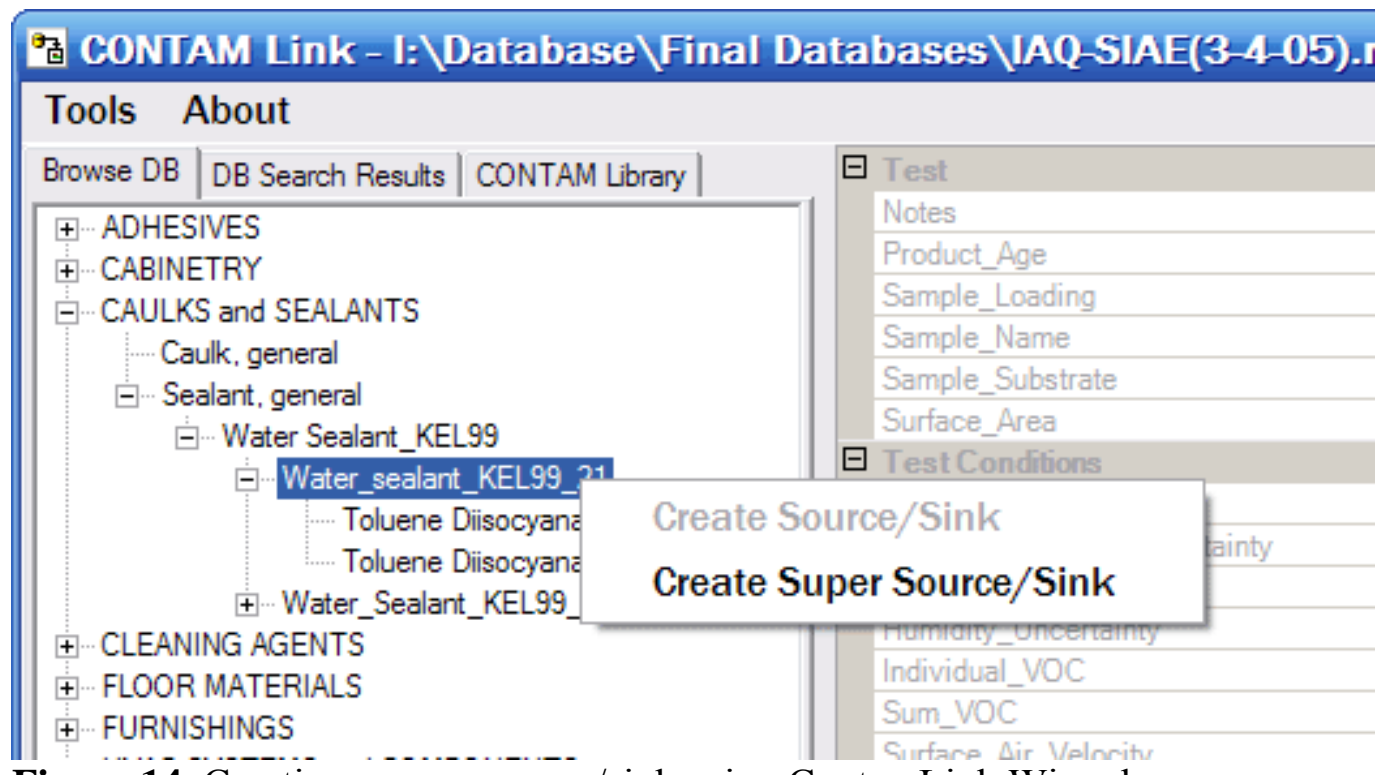

Figure 14. Creating a super source/sink using ContamLink Wizard.

Another difference when creating a super source/sink is that there is an additional step that is done first in the wizard. This step entails selecting which contaminants to include in the super source/sink (see Figure 15).

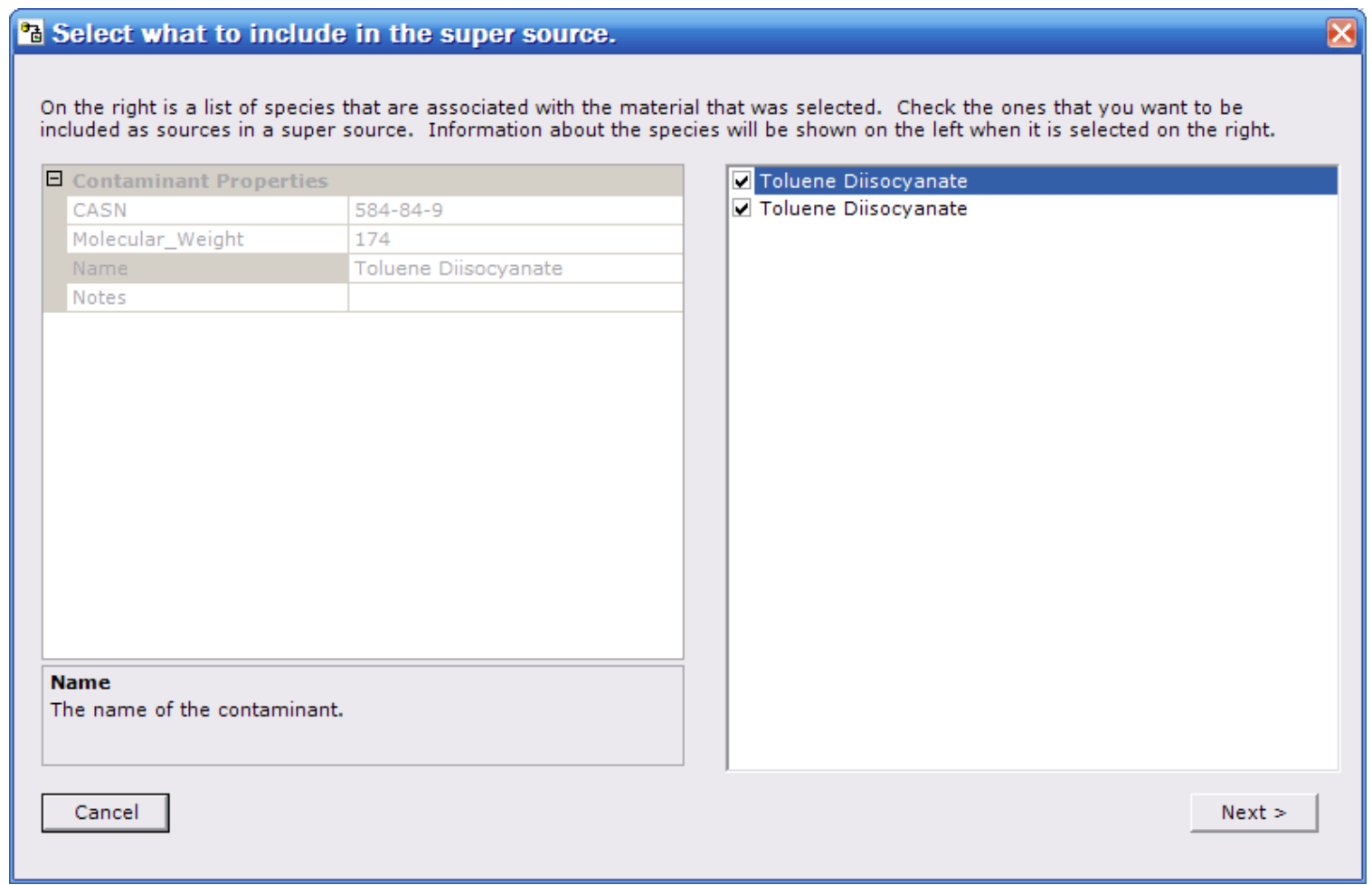

Figure 15. Selecting contaminants to include in the super source using ContamLink wizard. 
Each of these contaminants will have to have a species and a simple source/sink defined. The definition of these species and source/sinks has the same procedure as defining any other simple source/sink. These simple source/sinks will then be included in the super source/sink. After the simple source/sinks are defined you define the super source.

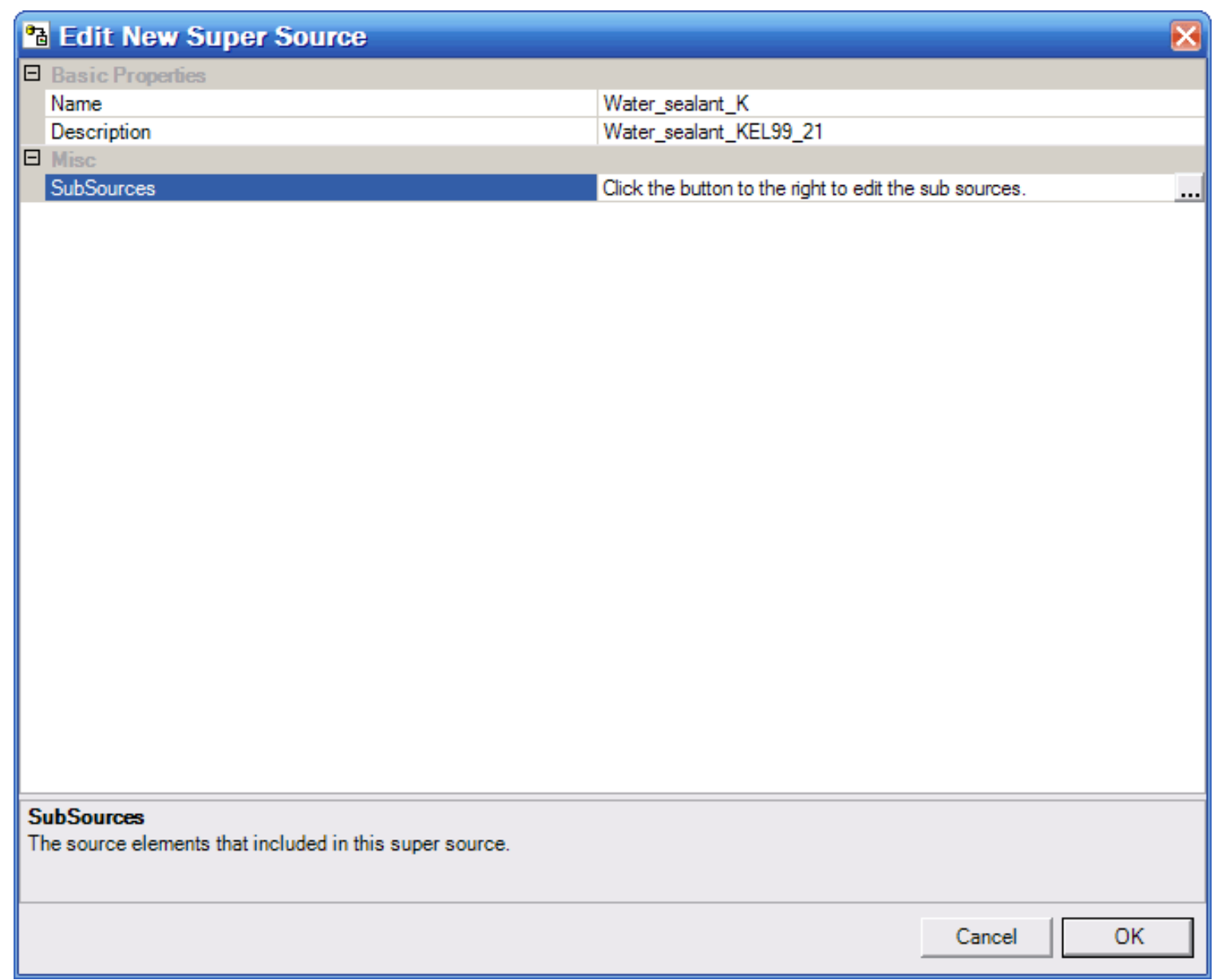

Figure 16. Defining subsources that make up super source using ContamLink wizard.

You can edit the sub source/sinks by pressing the small button by the right edge of the window, which is present in the SubSources row when it is selected. It will bring up the dialog box in Figure 17. 


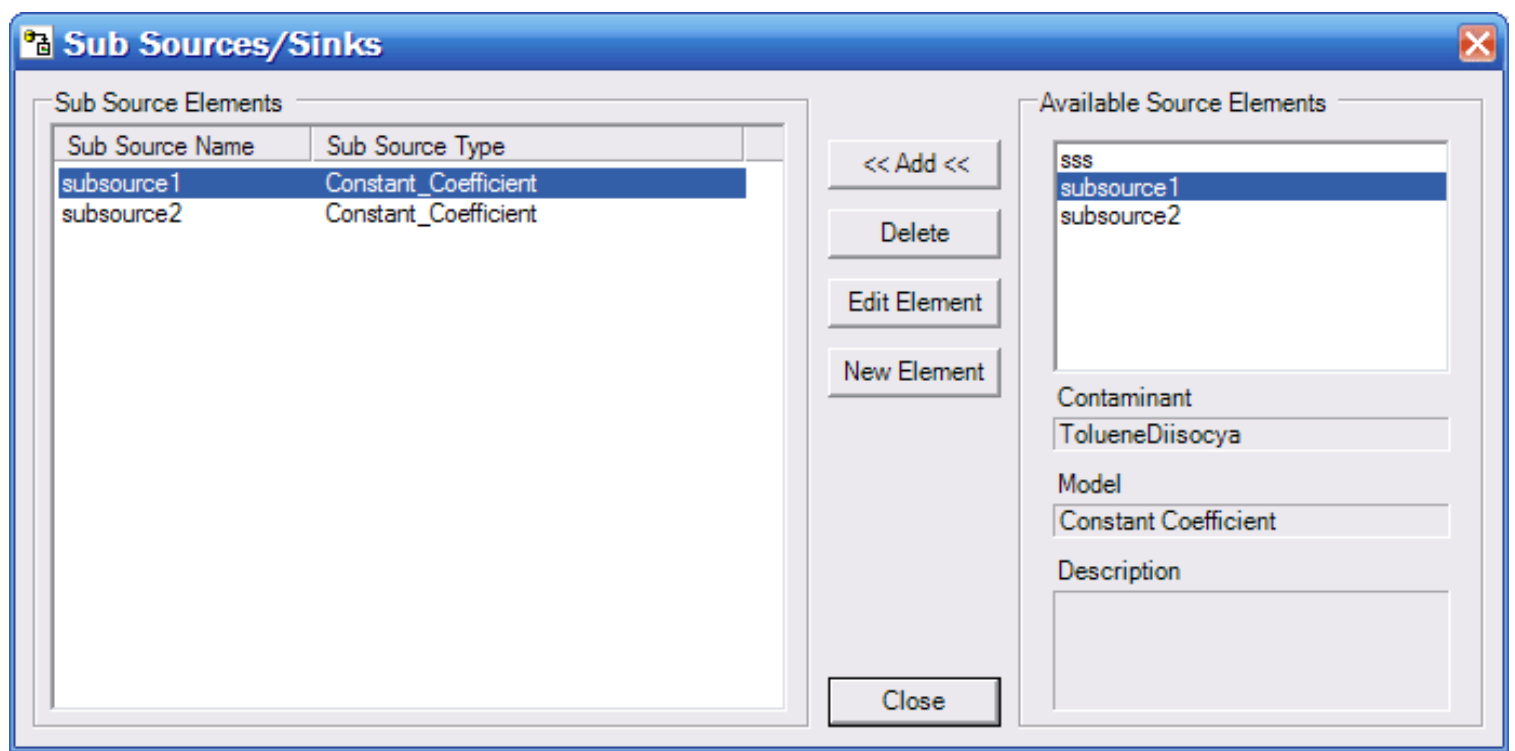

Figure 17. Defining subsources that make up super source using ContamLink wizard.

The simple source/sinks included in the super source/sink are shown on the left side of the window. On the right side of the window is a list of the available simple source/sinks that can be included in the super source/sink. One can edit the simple sources or create new simple source/sinks from this dialog. The user can also add or delete simple source/sinks to/from the super source/sink.

When finished defining the super source/sink and closing the dialog box with the OK button, the super source/sink will appear in the library manager. 